William \& Mary Law School

William \& Mary Law School Scholarship Repository

Faculty Publications

Faculty and Deans

Summer 2018

\title{
The Best and Worst of Contracts Decisions: An Anthology
}

Nathan B. Oman

Daniel Barnhizer

Scott J. Burnham

Charles R. Calleros

Larry T. Garvin

See next page for additional authors

Follow this and additional works at: https://scholarship.law.wm.edu/facpubs

Part of the Common Law Commons, and the Contracts Commons

Copyright c 2018 by the authors. This article is brought to you by the William \& Mary Law School Scholarship Repository.

https://scholarship.law.wm.edu/facpubs 


\section{Authors}

Nathan B. Oman, Daniel Barnhizer, Scott J. Burnham, Charles R. Calleros, Larry T. Garvin, Nadelle Grossman, F. E. Guerra-Pujol, Jeffrey L. Harrison, Hila Keren, Michael P. Malloy, Daniel P. O'Gorman, Deborah Post, Val Ricks, Rachel Arnow-Richman, Richard R. Carlson, Mark P. Gergen, Kenney Hegland, Nancy S. Kim, Jean Fleming Powers, and Cheryl B. Preston 


\title{
THE BEST AND WORST OF CONTRACTS DECISIONS: AN ANTHOLOGY
}

\begin{abstract}
The common law of contract is an intellectual and political triumph. In its mature form, it enables judges whose ideological goals may differ to apply doctrines that provide the right to make enforceable promises; with legislation, the common law also provides proper limits on that right. Lately, scholars have produced a flood of contract law theory that enriches our thinking about and grounding for contract law norms. But the real work of common law development has always occurred in the trenches-in judicial decisions. In those trenches and on the framework built there, some decisions matter far more than others, and jurists, scholars, and teachers draw on these key decisions to do their work. In the following collection of essays, scholars deeply familiar with judicial opinion in the common law of contract-twenty authors who have a collective 497 years writing, teaching, and thinking about contract law-identify the best and worst of contracts cases. Many of the cases are staple examples for practical and theoretical contracts scholarship. Many are taught to thousands of students each year. Many are routinely cited by courts. The essays explain, rebuke, extol, entertain, and inspire. They are brief but substantive. They set a basis for future commentary and establish a collective standard against which contracts decisions may be judged. They are vital study for contract law adjudication, scholarship, and teaching.
\end{abstract}

I. INTRODUCTION

888

A. An Intellectual Win. 889

B. A Political Success 892

C. Dialectical Decisionmaking

894

II. THE BEST OF CONTRACTS DECISIONS

Until We're Not All Realists Anymore: Wilkie v. Auto-Owners Insurance and Michigan's Neo-Formalist Jurisprudence of Contract Interpretation DANIEL BARNHIZER

Understated Elegance: Wood v. Lucy, Lady Duff-Gordon SCOTT J. BURNHAM

905

Why Pyeatte v. Pyeatte Might be the Best Teaching Tool in the Contracts Casebook

Charles R. CALleros

908

Kingston v. Preston (and Goodisson v. Numn, sort of) LARRY T. GARVIN.

Combating Limits of the Case Method with Quake Construction, Inc. v. American Airlines, Inc.

NADELLE GROSSMAN.

Hadley v. Baxendale: A Bayesian Analysis of the Hadley Rule F. E. GUERRA-PUJOL

Jacob \& Youngs, Inc. v. Kent JEFFREY L. HARRISON

Contracts' Enforcement and the Social Contract HILA KEREN.

900

Everywhere a Cluck-Cluck: Frigaliment Importing Co. v. B.N.S. Int'l Sales Corp.

Michael P. MALLOY.

912

ProCD, Inc. v. Zeidenberg: How an Opinion that Some Believe Deserves an "F" as a Law-School Exam Answer was one of the Greatest Contracts Opinions Ever Written

DANIEL P. O'GORMAN

Of Milk, Markets, Populism and Promissory Estoppel: State Bank of Standish v. Curry DEBORAH POST 
The Democratization of Contract Law: The Case of Mutual Promises

VAL RICKS

III. THE WORST OF CONTRACTS CASES

Asmus v. Pacific Bell and the "Unilateral" Employment Contract: Building the House of Cards Higher RACHEL ARNOW-RICHMAN

What is the Sound of One Form Flapping?: Hill v. Gateway 2000, Inc. and the Deconstruction of Individual Autonomy

DANIEL D. BARNHIZER

Webb v. McGowin: The Perils of "Result-oriented" Jurisprudence SCOTT J. BURNHAM

Kirksey v. Kirksey CHARLES CALlEROS \& VAL RICKS

Peevyhouse RICHARD R. CARLSON.

Scapegoats and the Common Law: Pinnel's Case, Cumber v. Wane, and the Legal Duty Rule LARRY T. GARVIN.

Mitchill v. Lath and Masterson v. Sine MARK P. GERGEN

Sherwood v. Walker: Replevin for Rose Redux F. E. GUERRA-PUJOL

Hadley v. Baxendale KENNEY HEGLAND

In Re Marriage of Witten: Subordinating Contract to "Public Policy" NANCY S. KIM

Mangled Metaphors: ProCD, Inc. v. Zeidenberg MICHAEL P. MALLOY

Justice Traynor and the Summer of Love: Misunderstanding the Parole Evidence Rule in Pacific Gas NATHAN B. OMAN.

Farash v. Sykes Datatronics, Inc. JEAN FLEMING POWERS

How Did We End Up in a World Where Browsewraps Are Enforced Even When They Waive All Consumer Rights? CHERYL B. PRESTON

Pillans and Rose v. Van Mierop and Hopkins: The Worst Way to Win VAL RICKS

For ease of reference, individual essays will be cited in footnotes in this anthology by their author's last name and a "short cite" version of the name of the case on which the author comments, e.g., "Arnow-Richman on Asmus," without any further citation.

Copyright remains with individual contributors.

\section{INTRODUCTION}

Five hundred years ago, the common law of contract was without substance. It was form-procedure. Plaintiffs picked a form of action, and common law judges made sure someone besides themselves answered all the hard questions; the parties, a jury, or a ritual determined the winner and the remedy. ${ }^{1}$ Judges ran a switch on a con-

1. Better expositions of this nature of early contract law include S.F.C. MILSOM, A NATURAL History OF THE COMMON LAW 29-43 (2003); J.H. BAKER, INTRODUCTION (BUT 
flicts-resolution railway. Thomas More, when Chancellor of England (1529-33), urged judges to lay tracks and control the trains. ${ }^{2}$ The problem, he said, was that the judges, "by the verdict of the jury[,] cast off all quarrels from themselves."3

The judges soon assumed greater authority, taking responsibility for the law's substance. The consideration requirement was in place by $1539,{ }^{4}$ and judges afterwards imposed doctrine upon doctrine. Over centuries, they created the common law of contract. That law is now mature, more or less, meaning that judges have tools to fix what they want to fix, and feel free to do so.

The law they created - the common law of contract-is a remarkable intellectual and political achievement.

\section{A. An Intellectual Win}

This judge-made law provides a right to call on the courts to enforce certain promises. It includes the right to make oneself a promisor of such a promise. The right to promise enforcement provides a more potent means for human beings to pursue happiness-to seek good. It boosts our willingness to trust persons farther from us and encourages them to trust us. Among other benefits, promise enforcement expands our ability to barter our own natural property-our time, talents, and work-for whatever else we desire. It (along with property rights) enables us to barter what we have for something better. It allows us better to organize and provide for others what they desire.

ESPECIALly Chapter 1), in II THe Reports of SiR John SPELman, 94 The PuBlications of THE SELdon Society (J.H. Baker ed. 1978); and A.W.B. SIMPSON, A History of THE COMMON LAW OF CONTRACT: THE RISE OF THE ACTION OF ASSUMPSiT 5-196 (1975). For example, under this system, most cases were brought under the debt form of action. SIMPSON, supra, at 424-26. If the parties planned, they created conditional bonds that gave the other party a more or less successful debt case, for the common law "treated the instrument as dispositive." Id. at 95. The bond itself did not answer whether a condition was met, so this went to a jury. Id. at 101. Absent an instrument, a debt defendant could choose to go to a jury or wage law. Id. at 137. Waging law meant the defendant's swearing on the Bible that he owed nothing. Id. at 138. "If he perjured himself he would undoubtedly imperil his soul," but perjury was not a crime at the time. Id. Thus, the instrument, the jury, and ritual resolved the cases. Of course, my general statement is reductionist a bit, but not much relative to today.

2. William Roper, The Life OF SiR Thomas MORE C. 1556, at 26 (Gerard B. Wegemer \& Stephen W. Smith eds., 2003); see also BAKER, supra note 1, at 41-43, 80-82. That it was contract law specifically that More urged reforming we owe to Mansfield, so it should be taken with salt. See Garrard Glenn, St. Thomas More as Judge and Lawyer, 10 FORDHAM L. REV. 187, 191-92 (1941) (citing Wyllie v. Wilkes (1780) 99 Eng. Rep. 331, 333).

3. ROPER, supra note 2, at 26.

4. David J. Ibbetson, Assumpsit and Debt in the Early Sixteenth Century: The Origins of the Indebitatus Count, 41 CAMBRIDGE L.J. 142 passim (1982); see MILSOM, supra note 1 , at 45 (tying consideration's rise to dissatisfaction with juries' freedoms). 
Because no one can know more of what we desire than we ourselves, the right to extend our powers through legally enforceable promises (and property law) gives hope for shifting or allocating much of the world's resources to those who desire them for their own happiness and for the greater good that they seek.

Because the practice of contracting is the source of such hope and is ingrained in our culture, promise enforcement is also needed to serve corrective justice. Some who reasonably rely on promises justly deserve a remedy that requires promise enforcement. Some promisors who are unjustly enriched because of their failed promises should be called to account. Moreover, enforcement by courts replaces the private violence that might otherwise occur in the name of promise enforcement. Promise enforcement is a cornerstone of trust, order, and liberty.

Of course, the law limits this right. The law limits what promises are enforced. Promise enforcement law can be used by almost anyone, so conduct invoking it should be relatively clear. Law defining this conduct comprises the rules of offer and acceptance, consideration, what terms the contract includes, and what they mean. ${ }^{5}$ Once these thresholds are met, the law allows promisors to undercut these rules. Thus, some promises induced by misrepresentation, coercion, or mistake; some promises made orally; and some promises made expressly conditional when the condition is not met- these are not enforced pursuant to relatively clear rules. ${ }^{6}$

Other boundaries are less clear but give judges tools to reach just results, such as (i) the standards limiting enforcement of promises that are unconscionable, or whose purpose is frustrated, or where performance is impracticable; or (ii) more diffuse public policy. ${ }^{7}$ Still other rules allow judges to shape the contours of liability towards just results; for example, the obligation of good faith and the rules subjecting promises to constructive conditions that courts impose in almost every contract. ${ }^{8}$ Even when judges agree that a promise should bind and breach occurred, remedies are limited by the bargain

5. See, e.g., RESTATEMENT (SECOND) OF CONTRACTS ch. 3, ch. 4, \& ch. 9 (AM. LAW INST. 1981). Of course, not every issue addressed in these chapters is resolved by a clear rule, but rules for the most part, in these areas, yield predictability to those who plan carefully. The Restatement is, of course, not law, but it has the persuasive weight of at least two treatises.

6. See, e.g., id. chs. 5-7\& §§ 224-29.

7. See, e.g., id. § 208, ch. 11 , \& ch. 8.

8. See, e.g., id. $\$ 205 \&$ ch. 10. 
the parties made and are subject to the court's (or jury's or plaintiff's) discretion. $^{9}$

Sometimes, a field of promises is so choked with difficulties that legislators step in with limitations. In this way, other boundaries have been placed on the legal enforcement of promises involving sale of securities, ${ }^{10}$ sale of goods, ${ }^{11}$ business formation and operation, ${ }^{12}$ employment, ${ }^{13}$ arbitration, ${ }^{14}$ insurance,${ }^{15}$ plea-bargaining,${ }^{16}$ competition, ${ }^{17}$ bankruptcy, ${ }^{18}$ and a host of other activities. ${ }^{19}$ (Most of these limiting doctrines figure so prominently in the law's web of rules that they merit separate classes in law school.) Even where legislation does not co-opt the field, judges may step in to modify contract law to fit the context, as they did with some areas of family law ${ }^{20}$ and the

9. See, e.g., id. ch. 16 (giving rights to measures of damages in the alternative and affording the plaintiff some choice in the matter); see also, e.g., SIGA Techs., Inc. v. PharmAthene, Inc., 132 A.3d 1108, 1128-38 (Del. 2015) ("We review [the trial court's] damages determination for abuse of discretion . . .."); Jalbert v. Eagle Rigid Spans, Inc., 891 N.W.2d 135, 141-42 (N.D. 2017).

10. See, e.g., Securities Act of 1933, ch. 38, 48 Stat. 74 (codified as amended at 15 U.S.C. $\S \S 77 \mathrm{a}-77$ aa (2017)); Securities Exchange Act of 1934, chs. 393-94 \& 404, 48 Stat. 881 (codified as amended at 15 U.S.C. \$78a et seq.); Sarbanes-Oxley Act of 2002, Pub. L. No. 107-204, 116 Stat. 745 (codified in scattered sections of 15 U.S.C. and 18 U.S.C.); DoddFrank Wall Street Reform and Consumer Protection Act of 2010, Pub. L. No. 111-203, 124 Stat. 1376; Jumpstart Our Business Startups Act of 2012, Pub. L. No. 112-106, 126 Stat. 306 (codified in scattered sections of 15 U.S.C.).

11. See, e.g., U.C.C art. 2 (AM. LAW INST. \& UNIF. LAW COMM'N 2002); see also, e.g., Magnusson-Moss Warranty-Federal Trade Commission Improvement Act, Pub. L. No. 93637, 88 Stat. 2183 (codified in 15 U.S.C. § 2301 et seq.).

12. See, e.g., Model Business Corporations Act (AM. BAR. Ass'N 2016); Uniform Partnership Act (1997) (last amended 2013); Uniform Limited Partnership Act (2001) (last amended 2013); Uniform Limited Liability Company Act (2006) (last amended 2013).

13. See, e.g., Fair Labor Standards Act of 1938, ch. 676, 52 Stat. 1060 (codified as amended at 29 U.S.C. $§ 201$ et seq.); Occupational Safety and Health Act of 1970, Pub. L. No. 91-596, 84 Stat. 1590 (codified as amended at 29 U.S.C. $\$ \S 651$ et seq.); Employee Retirement Income Security Act of 1974, Pub. L. No. 93-406, 88 Stat. 829 (codified as amended in scattered sections of 26 U.S.C. and 29 U.S.C.).

14. See, e.g., Federal Arbitration Act, 9 U.S.C. $\$ \S 1-16$ (2000); Uniform Arbitration Act (2000).

15. E.g., Steven PlitT ET AL., Couch On Insurance (3d ed. 2016) (1995).

16. See, e.g., Watkins v. Commonwealth, 491 S.E.2d 755 (Va. Ct. App. 1997).

17. See, e.g., Sherman Antitrust Act, 15 U.S.C. $\S \S 1-7$ (1890); Clayton Act, 15 U.S.C. $\$ \S 12-27$ (1914). States also enforce competition laws. See the statutes listed at Statutes, AMERICAN ANTITRUST INSTITUTE, http://www.antitrustinstitute.org/content/statutes-0 [https://perma.cc/S3CQ-T2M2].

18. See 11 U.S.C. (2012).

19. Such things as door-to-door sales, 16 C.F.R. $\$ 429$ (2015); the mailing of unordered merchandise, 39 U.S.C. $\S 3009$ (2012); agreements to pay debts discharged in bankruptcy, 11 U.S.C. \$ 524 (2012); and many others.

20. See, e.g., Deborah Zalesne, The Intersection of Contract Law, Reproductive Technology, and the Market: Families in the Age of ART, 51 U. RICH. L. REV. 419 (2017) (reviewing hesitancy to apply contract principles but recommending that they apply to assisted 
contracts of lawyers. ${ }^{21}$ Finally, the law steps in to assist when promise enforcement and markets are inadequate to meet other important goals-for instance, creating a safety net for those who cannot participate, regulating activities that for a variety of reasons are not done well through contracting, or taxing for various government purposes; and these government activities also limit what can be done through contracting.

The point of recounting these limitations here (and remembering those omitted) is to call attention to two things:

(1) The difficulty, cost, and complexity of maintaining promise enforcement. (Law schools teach Contracts to first-year students and then must train them to use that law correctly in Securities Regulation, Sales of Goods, Business Entities, Employment Law, Antitrust, Consumer Law, Insurance Law, Payment Systems, Secured Transactions, Bankruptcy Law, Family Law, Professional Responsibility, and Remedies!)

(2) That maintaining the right of promise enforcement at such great cost declares unequivocally the vitality and importance of the common law of contract, by which that right is chiefly created.

We would not so carefully nurse these limitations unless we relied deeply and necessarily on the activity we limit. We would replace it.

The creation and maintenance of such a complex system so that the right to enforceable promises is retained and its benefits reaped is an amazing intellectual achievement.

\section{B. A Political Success}

The creation and maintenance of this system is also a political achievement. The continued existence of any sort of coherent contract law in the United States requires the voluntary cooperation of every state judiciary and the federal judiciary (and secondarily the lawyers who create contracts and litigate them). The fact that contract law exists under such conditions is astonishing. Contract law is not constitutionally dictated. Each state in the United States has a court of last resort or a legislature which could change the law away from common norms! Contract law also requires the cooperation, or at least acquiescence, of the populace governed by those contractshundreds of millions of people in the United States and throughout the world.

reproduction arrangements); Developments in the Law-The Law of Marriage and Family: Marriage as Contract and Marriage as Partnership: The Future of Antenuptial Agreement Law, 116 HARV. L. REV. 2075 (2003).

21. See, e.g., Joseph M. Perillo, The Law of Lawyers' Contracts Is Different, 67 FORDHAM L. REV. 443 (1998). 
The judges who continue to write the law, whether they be elected or appointed, tend to be sophisticated political actors, and no two will agree completely on even mundane contract law issues. Their views likely run the gamut from left to right and hit positions not squarely between either pole. For instance, one judge may see promise enforcement as an aid to maximizing utility; another judge may see it as merely an acceptable method of harnessing self-interest to create only non-essential goods and services; and another might see it only as a means to establish corrective justice. Still another might see the right to make an enforceable promise as the natural right of each individual to pursue happiness; or, a judge might see contracting activity as a means to impose on the populace some moral training civilization needs.

But these judges do not need to agree on contract law's ultimate goals to apply the doctrines of consideration, duress, constructive conditions, and third-party beneficiaries. ${ }^{22}$ Judges and those subject to their decisions can support promise enforcement for any number of philosophical or pragmatic reasons. ${ }^{23}$ The ideological noncommitment of basic contract doctrines allows judges to reach agreement in individual cases both from and against a wide range of other philosophical or even ideological commitments. ${ }^{24}$ Moreover, when political power shifts ideologically, contract law's lack of overt ideological commitment renders it innocuous enough that the newly empowered leave its core doctrines in place, or at least have thus far.

Of course, this noncommitment-this necessary condition of philosophical pluralism so helpful to contract law's existence-has a downside. Some name it "formalist," a structural criticism highlighting that contract doctrine can be misused by those with misguided (or perverse) political goals. ${ }^{25}$ Certainly, contract law's modest goal-to

22. See discussion infra Post on Curry p. 943 (listing theoretical lenses through which the majority opinion could be viewed).

23. The law's lack of explicit unifying theory allows pluralism among not only theorists but also judges who have to work together, lawyers who must argue before them, and clients who must live with what judges decide. Commentators embracing pluralism include BRIAN H. BIX, CONTRACT LAW: RULES, THEORY AND CONTEXT (2012); ROBERT A. HiLlmaN, The RICHNESS of CONTRACT LAW (1997); Gregory Klass, Three Pictures of Contract: Duty, Power, and Compound Rule, 83 N.Y.U. L. REV. 1726, 1769-83 (2008). Of course, so much contract law exists that most any reasonable (or even plausible) political angle can find some legal cover.

24. This facet of contract law allows professors from across the political spectrum uniformly to despise some cases, as Daniel Barnhizer recounts. See infra Barnhizer on Hill p. 956; see also infra Garvin on Pinnel's Case and Cumber p. 974. It also allows judges to agree on doctrinal formulations while disagreeing on applications as the scope of a doctrine is developed. See infra Post on Curry p. 943. We bet that you will admit distaste or admiration for at least some of the worst and best cases included, respectively.

25. E.g., Roberto MANGABEIRA UNGER, THE CRITICAL LEGAL STUdies MovemENT 86 (1986); Duncan Kennedy, Form and Substance in Private Law Adjudication, 89 HARV. L. 
enforce promises that should be enforced-will be met differently depending on who is in power. But the common law of contracts has survived throughout the life of our country. Flawed or not, its success merits grudging or celebratory respect. Nothing else has beaten it or come close to doing so.

\section{Dialectical Decisionmaking}

Though mature, contract law will continue developing. Most of contract law remains common law. Judicial decisions will affirm the law's substance but will also expand, shrink, and shift the law to meet new challenges.

Those who care about contracting must therefore care about judicial decisions in contract law. Such decisions can be done well or badly. Done well, they add to contract law's usefulness and luster. Done badly, they make promise enforcement or its limits more difficult to maintain.

Yet identifying decisions as good or ill is no easy task. Helping contract law's delicate, relatively apolitical balance between freedom and limitations - crafted over five hundred years-requires deep knowledge of how doctrines work together, a practical understanding of facts on the ground, the ability to persuade others on and off the courts, and wisdom to see (or at least sense) the law's direction.

It helps if decisions are well-documented. Karl Llewellyn hoped each decision of note would be followed by an opinion "which ... aims to tell any interested person what the cause is and why the decision - under the authorities - is right, and perhaps why it is wise." ${ }^{26}$ A well-crafted opinion can make or break a contract law decision.

A great deal of recent advice exists regarding what contract law is and should be. ${ }^{27}$ Much of it is helpful for justifying promise enforce-

REV. 1685 (1976). Unger prescribes "a continuing comparison between the ideal projects for human coexistence that give sense and authority to established doctrine and the actual reality of the social practices that current law and legal ideas help reenact." UNGER, supra, at 86 . He also advocates "the search for the conditions under which a regime of contract can avoid becoming the disguise of a power order without being constantly overridden by correction." Id. The search has not ended, and the criticism implicit in it retains force.

26. KARL N. LlEWELlyn, THE COMMON LAW TRADition: DECIDING APPEALS 26 (1960).

27. See, e.g., HANOCH DAGAN \& MiCHAEL HELlER, THE CHOICE THEORY OF CONTRACTS (Cambridge Univ. Press 2017); NATHAN B. OMAn, THE Dignity of Commerce: MaRkETS AND THE MORAL FOUNDATIONS OF CONTRACT LAW (2016); BIX, supra note 23; MARGARET Jane Radin, BoIlerplate: The Fine Print, VAnishing Rights, and the Rule of LaW (2012); Eric A. Posner, Contract LAW And Theory (2011); RAndy E. BARnetT, ThE OXFORD INTRODUCTIONS TO U.S. LAW: CONTRACTS (Dennis Patterson ed. 2010); ECONOMICS OF CONTRACT LAW (Douglas G. Baird, ed. 2007); F.H. BUCKLEY, JusT EXCHANGE: A THEORY of Contract (2005); Stephen A. SMith, Contract THEORY (2004); Dori Kimel, From PROMISE TO CONTRACT: TOWARDS A LIBERAL THEORY OF CONTRACT (2003); THE THEORY OF CONTRACT LAW: NEW ESSAYS 58 (Peter Benson ed. 2001) (featuring entries by Richard 
ment or certain limitations in a general or theoretical way, but mostly it focuses on principles, policies, and incentives rather than actions, cases, motives, and deals. ${ }^{28}$ It is all by nature too theoretical, too antecedent, to assist a judge, in any significant way, in seeing what rule should apply to any given set of facts before her or how a rule should be applied to those facts, what remedy should be given, how to write a particular opinion, or what impact the opinion will have on the law's development. ${ }^{29}$ These are matters of practical judgment-not theory, history, or even social policy. So, Llewellyn said, "The very reason that appellate courts exist is that there is doubt." ${ }^{30}$ Cases cannot be solved in advance, nor can their impact on the law be seen fully. Thus, Benjamin Cardozo, who cared about contract law, tentatively opined of common law development, "What is good in it endures. What is erroneous is pretty sure to perish." ${ }^{1}$

But perhaps we can help it along.

In the following essays, authors deeply familiar with judicial opinion in the common law of contract-authors who have a collective 497 years teaching, thinking, and writing about contract law-identify the best and worst of contracts cases. Each was asked to propose a candidate for the best contracts case ever decided, or the worst, and briefly say why. No two authors agree on the criteria. The cases chosen range from obscure to infamous, but all are or should be canonical. Many are staple factual examples for practical and theoretical contracts scholarship; many are taught to thousands of students each year; and many are cited daily in courts.

The essays explain, rebuke, extol, entertain, and inspire.

Craswell, Michael J. Trebilcock and Steven Elliott, T.M. Scanlon, Peter Benson, Melvin A. Eisenberg, and James Gordley); Charles Fried, ConTraCT AS Promise: A THEORY of Contractual Obligation (1981); Robin Bradley Kar, Contract as Empowerment, 83 U. CHI. L. REV. 759 (2016); Todd D. Rakoff, The Five Justices of Contract Law, 2016 WISC. L. REV. 733 (2016); Peter Linzer, Contract as Evil, 66 HASTINGS L.J. 971 (2015); Gregory Klass, supra note 23; Daniel Markovits, Contract and Collaboration, 113 YALE L.J. 1417 (2004); see also PHILOSOPHICAL Foundations of CONTRACT LAW (Gregory Klass et al. eds., Oxford Univ. Press 2014); Symposium-Contract as Promise at 30: The Future of Contract Theory, 45:3 SUFFoLK U.L. REV. 601 (2012).

28. Of course, not all are so general. This one is not: NANCY KIM, WRAP CONTRACTS: FounDATIONS AND RAMIFICATIONS (2013). Radin's book also is not, to an extent. See RADIN, supra note 27. But even works focused on actual contracts and cases do not remove the need for judicial fitting of new cases to existing rules.

29. Litigation is a messy business, too. See infra Burnham on Wood p. 905, Carlson on Peevyhouse p. 969, Gergen on Mitchell and Masterson p. 982, Kim on Marriage of Witten p. 994.

30. LLEWELLYN, supra note 26, at 6.

31. Benjamin N. Cardozo, The Nature of the Judicial Process 178 (Yale Univ. Press 1921). 
But the scatter plot of scholarship yields some correlations. What makes a contracts decision best or worst? What do these scholars ask of the judge in a contracts case?

As might be expected, among the scholars' points, some trendlines of scholarly "best fit" apply to appellate adjudication generally. The essays advise as follows: Please report the facts accurately, in their full context. ${ }^{32}$ Respect the jury's function. ${ }^{33}$ Report the law accurately, even if it is against your conclusions. ${ }^{34}$ Follow the law,$^{35}$ or if you decide not to, explain clearly why not and justify your decision. ${ }^{36}$ Decide a case for the parties, not just for your own (or other) purposes, whatever they may be ${ }^{37}$ Be willing to address problems, ${ }^{38}$ but respect for the law requires that you justify new solutions in terms of older principles and with clear explanations of policy or other supporting jurisprudential argument. ${ }^{39} \mathrm{We}$ scholars welcome your synthesizing of doctrine ${ }^{40}$ and even fundamental doctrinal changes if necessary, ${ }^{41}$ but please stick to relevant argu-

32. See infra Arnow-Richman on Asmus p. 952, Barnhizer on Hill p. 956, Barnhizer on Wilkie p. 901, Burnham on Wood p. 905, Calleros on Pyeatte p. 908, Calleros \& Ricks on Kirksey p. 965, Carlson on Peevyhouse p. 969, Gergen on Masterson p. 982, Grossman on Quake Constr. p. 919, Harrison on Jacob \& Youngs p. 927, Hegland on Hadley p. 992, Malloy on Frigaliment p. 936, Post on Curry p. 943, Preston on Lochner p. 1012. For facts, accuracy is a baseline and perceptiveness a plus.

33. See infra Calleros \& Ricks on Kirksey p. 965, Guerra-Pujol on Sherwood p. 989, Hegland on Hadley p. 992.

34. See infra Arnow-Richman on Asmus p. 952, Barnhizer on Hill p. 956, Burnham on Webb p. 961, Carlson on Peevyhouse p. 969, Gergen on Mitchell and Masterson p. 982, Guerra-Pujol on Sherwood p. 989, Malloy on ProCD p. 998, Oman on PG\&E p. 1002.

35. See infra Burnham on Webb p. 961; Garvin on Pinnel's Case and Cumber p. 974. Scorn is well-earned by "the flat ignoring of authority in point which is technically controlling; the presentation of prior cases as if they held what they do not, or did not, hold what they did; the ignoring or outright twisting of vital facts in the record in hand; and the like." LLEWELLYN, supra note 5, at $27 \mathrm{n} .18$.

36. See infra Arnow-Richman on Asmus p. 952, Barnhizer on Hill p. 956, Calleros \& Ricks on Kirksey p. 965, Carlson on Peevyhouse p. 969, Gergen on Mitchell and Masterson p. 982, Hegland on Hadley p. 992, Malloy on ProCD p. 998.

37. See infra Burnham on Wood p. 905, Gergen on Mitchell and Masterson p. 982, Gross on Quake Constr. p. 919, Harrison on Jacob \& Youngs p. 927, Kim on Marriage of Witten p. 994, Malloy on Frigaliment p. 936, Oman on PG\&E p. 1002.

38. See infra Garvin on Kingston and Goodison p. 912, Grossman on Quake Constr. p. 919, Keren on Williams p. 931, Kim on Marriage of Witten p. 994, Malloy on Frigaliment pp. 936, O'Gorman on ProCD p. 939, Post on Curry p. 943. Llewellyn noted, "The horrible thing here is that unwillingness to face up to responsibility for needed change in law or inability to discover and phrase a broadly solving rule can in a good cause lead even an upright and careful court to blacken the judicial shield . . ." LLEWELLYN, supra note 26, at 27 n. 18 .

39. See supra note 36; See infra Oman on PG\&E p. 1002.

40. See infra Calleros on Pyeatte p. 908, Garvin on Kingston and Goodison p. 912, Grossman on Quake Constr. p. 919, Keren on Williams p. 931, Malloy on Frigaliment p. 936.

41. See infra Garvin on Kingston and Goodison p. 912, O'Gorman on ProCD p. 939, Ricks on Mutual Promises p. 947. 
ments. ${ }^{42}$ The more change you demand, the clearer and more persuasive your arguments must be. ${ }^{43}$ We will not be fooled by non sequiturs, straw men, and the like; ${ }^{44}$ rather than engage in these, treat all parties, your judicial opponents, and everyone's arguments with respect. Please set down law that lawyers and citizens can understand and follow. ${ }^{45}$ Write clearly and concisely, ${ }^{46}$ as if to first-year law students. ${ }^{47}$ Recognize that your decisions teach. ${ }^{48}$ (All this is good advice for any court on any issue. To an extent, good decisions, like happy families, are all alike. ${ }^{49}$

The essays also reveal facets of contract law. For instance, they reveal the centrality to the contract law project of the right to make enforceable promises ${ }^{50}$ and the importance of policing that right's limits carefully to maintain contract law's delicate balance..$^{51}$

42. See infra Arnow-Richman on Asmus p. 952, Burnham on Webb p. 961, Gergen on Mitchell and Masterson p. 982, Grossman on Quake Constr. p. 919, Harrison on Jacob \& Youngs p. 927, Malloy on ProCD p. 998, O’Gormon on ProCD p. 939, Oman on PG\&E p. 1002, Post on Curry p. 943.

43. See infra Gergen on Masterson p. 982, Kim on Marriage of Witten p. 994, Oman on PG\&E p. 1002, Ricks on Pillans p. 1016.

44. See most of the essays in Worst OF CONTRACTS, infra Part III.

45. See infra Arnow-Richman on Asmus pp. 952, Garvin on Kingston and Goodison p. 912, Oman on PG\&E p. 1002.

46. See infra Barnhizer on Wilkie p. 901, Burnham on Wood p. 905, Calleros on Pyeatte p. 908, Grossman on Quake Constr. p. 919, Harrison on Jacob \& Youngs p. 927, Malloy on Frigaliment p. 936, Post on Curry p. 943. Poor writing detracts from the opinion and the decision. See Malloy on ProCD p. 998, Oman on PG\&E p. 1002.

47. See infra Barnhizer on Wilkie p. 901, Burnham on Wood p. 905, Calleros on Pyeatte p. 908, Calleros \& Ricks on Kirksey p. 965, Grossman on Quake Constr. p. 919, Malloy on Frigaliment p. 936, Post on Curry p. 943. How a case teaches is often a criterion. After all, lawyers learn law from opinions, and are instructed how to argue the next case in the line. If an opinion's wisdom is noticeable by neophytes, it is plain to the learned. Teachers want students to model the great, so students study many great cases. Conversely, sometimes students need a sample of shoddy work, and the worst cases paint contrasts more vividly.

48. See infra Keren on Williams p. 931.

49. Apologies to LEO TOLSTOY, ANNA KARENINA 1 (1878) (Constance Garnett trans., The Project Gutenberg 1998), http://www.gutenberg.org/files/1399/1399-h/1399-h.htm [https://perma.cc/VU5V-9AU3] (ebook).

50. See infra Barnhizer on Hill p. 956, Barnhizer on Wilkie p. 901, Calleros on Pyeatte p. 908, Carlson on Peevyhouse p. 969, Garvin on Pinnel's Case and Cumber p. 974, Hegland on Hadley p. 992, Kim on Marriage of Witten p. 994, Oman on PG\&E p. 1002, Preston on Lochner p. 1012, Ricks on Mutual Promises p. 947, Post on Curry p. 943. The essays imply that contractual freedom is not a zero-sum game. No one is misled by the argument that contractual freedom requires allowing one party to step on another. Either both parties' powers are expanded, or contractual freedom is unchanged or limited.

51. See infra Arnow-Richman on Asmus p. 952, Calleros \& Ricks on Kirksey p. 965, Garvin on Kingston and Goodison p. 912, Grossman on Quake Constr. p. 919, Guerra-Pujol on Sherwood p. 989, Harrison on Jacob \& Youngs p. 927, Hegland on Hadley p. 992, Keren on Williams p. 931, Kim on Marriage of Witten p. 994, O’Gorman on ProCD p. 939, Preston on Lochner p. 1012, Post on Curry p. 943. 
The essays suggest that only a few cases are truly great because they change doctrine foundationally; ${ }^{52}$ however, the most recent was decided before the Revolutionary War. ${ }^{53}$ At this late date, accuracy in stating the law ${ }^{54}$ may well be more valuable than doctrinal creativity-which can backfire..$^{55}$

The scholars' judgments imply a certain permanence in the principles that inform the law while recognizing doctrinal changes over time. ${ }^{56}$ They suggest a role for formalism ${ }^{57}$ but invite substantive discussion. ${ }^{58}$ They believe, with Fuller, that remedies play a vital role. ${ }^{59}$ They also imply that formation doctrines still matter. ${ }^{60}$

Though most contract cases seek money damages for real economic harm, money is not usually an end in itself; the better cases take account of this. ${ }^{61}$

52. Only two of the ten best cases are doctrinally foundational.

53. See infra Garvin on Kingston p. 912, O'Gormon on ProCD p. 939, Ricks on Mutual Promises p. 947. Cf. infra Guerra-Pujol on Hadley p. 923 with Hegland on Hadley p. 992.

54. The following entries rate a case worst partly for the opinion's misstating or misapplying the law. See infra Arnow-Richman on Asmus p. 952, Barnhizer on Hill p. 956, Burnham on Webb p. 961, Garvin on Pinnel's Case and Cumber p. 974, Gergen on Mitchell and Masterson p. 982, Guerra-Pujol on Sherwood p. 989, Malloy on ProCD, p. 998, Oman on $P G \& E$ p. 1002 . On the other hand, the following entries rate a case best partly for stating and applying the law correctly: Grossman on Quake Constr. p. 919, Harrison on Jacob \& Youngs p. 927, Malloy on Frigaliment p. 936, Post on Curry p. 943.

55. See infra Barnhizer on Hill p. 956, Gergen on Masterson p. 982, Oman on PG\&E p. 1002, Preston on Lochner p. 1012, Ricks on Pillans p. 1016.

56. See infra Arnow-Richman on Asmus p. 952, Barnhizer on Hill p. 956, Burnham on Webb p. 961, Burnham on Wood p. 905, Calleros \& Ricks on Kirksey p. 965, Garvin on Kingston p. 912, Grossman on Quake Constr. p. 919, Keren on Williams p. 931, Malloy on Frigaliment p. 936, Malloy on ProCD p. 998, Post on Curry p. 943.

57. See infra Barnhizer on Wilkie p. 901, Calleros \& Ricks on Kirksey p. 965, Post on Curry p. 943.

58. See infra Arnow-Richman on Asmus p. 952, Barnhizer on Hill p. 956, Calleros \& Ricks on Kirksey p. 965, Garvin on Pinnel's Case and Cumber p. 974, Gergen on Mitchell and Masterson p. 982, Guerra-Pujol on Sherwood p. 989, Harrison on Jacob \& Youngs p. 927, Keren on Williams p. 931, Kim on Marriage of Witten p. 994, O'Gorman on ProCD p. 939, Post on Curry p. 943.

59. See infra Calleros on Pyeatte p. 908, Carlson on Peevyhouse p. 969, Guerra-Pujol on Hadley p. 923, Harrison on Jacob \& Youngs p. 927, Hegland on Hadley p. 992, Keren on Williams p. 931, Post on Curry p. 943. On Fuller, see Lon L. Fuller \& William R. Perdue, Jr., The Reliance Interest in Contract Damages (pts. 1 \& 2), 46 YALE L.J. 52, 373 (19361937).

60. See infra Arnow-Richman on Asmus p. 952, Barhnizer on Hill p. 956, Burnham on Webb p. 961, Burnham on Wood p. 905, Calleros on Pyeatte p. 908, Calleros \& Ricks on Kirksey p. 965, Garvin on Pinnel's Case and Cumber p. 974, Malloy on Frigaliment p. 936, Malloy on ProCD p. 998, O'Gorman on ProCD p. 939, Post on Curry p. 943, Ricks on Pillans p. 1016, and Ricks on Mutual Promises p. 947.

61. See infra Arnow-Richman on Asmus p. 952, Burnham on Webb p. 961, Calleros on Pyeatte p. 908, Calleros \& Ricks on Kirksey p. 965, Carlson on Peevyhouse p. 969, Garvin on Pinnel's Case and Cumber p. 974, Grossman on Quake Constr. p. 919, Harrison on Jacob \& 
We also learn here that, in contract law, even great judges are not consistent, ${ }^{62}$ and the summer of 1968 was not Roger Traynor's best. ${ }^{63}$

Finally, the essays reveal a great deal of wisdom regarding why contract law is vital to our lives and must be preserved, corrected, and nurtured. These essays are vital commentary for contract law adjudication, scholarship, and teaching.

-Val Ricks

Youngs p. 927, Hegland on Hadley p. 992, Keren on Williams p. 931, Kim on Marriage of Witten p. 994, Preston on Lochner p. 1012, Post on Curry p. 943.

62. Compare Garvin on Kingston p. 912, with Ricks on Pillans p. 1016.

63. See infra Oman on PG\&E p. 1002, Gergen on Masterson p. 982. 
II. The Best of Contracts Decisions 


\section{Until We're Not All Realists Anymore: Wilkie v. Auto-Owners Insurance and Michigan's Neo-Formalist Jurisprudence of Contract Interpretation}

\section{DANIEL BARNHIZER ${ }^{*}$}

The phrase, "we are all [legal] realists now," as Michael Green notes, has been "so often said that it has become a cliché to call it a 'cliché." "' Except when we are not, as the Michigan Supreme Court indicated in a series of cases beginning with Wilkie v. Auto-Owners Insurance Co. ${ }^{2}$ in 2003 and culminating with Rory $v$. Continental Inssurance Co. ${ }^{3}$ in 2005. Although this Essay focuses on Wilkie, this line of cases not only provides significant pedagogical benefits in terms of teaching contract interpretation but also demonstrates the power of jurisprudence to control development of legal doctrine. Moreover, these cases indicate, in Michigan at least, that formalist concepts still have a place in modern contract law and jurisprudence.

In Wilkie, Janna Frank and her passenger, Paul Wilkie, were struck by underinsured motorist Stephen Ward. ${ }^{4}$ Ward's Michigan nofault insurance policy limit was $\$ 50,000$, while Wilkie's policy-besides state-mandated coverages and limits-had additional underinsured motorist coverage of $\$ 100,000$ per person up to a limit of $\$ 300,000$. Wilkie's underinsured motorist coverage also provided that the limit of liability for such coverage shall not exceed "the amount by which the Underinsured Motorist Coverage limits $[\$ 100,000$ per person, up to $\$ 300,000$ per occurrence] . . exceeds the total limits of all bodily injury liability bonds and policies available to the owner ... of the underinsured automobile." Finally, Wilkie's policy also provided that AutoOwners' liability would not be increased because of the number of claims made or persons injured. ${ }^{6}$

* Professor of Law, Bradford Stone Faculty Scholar, Michigan State University College of Law. Thanks to Research Assistant Nina Lucido for research and assistance in preparing this essay.

1. Michael S. Green, Legal Realism as Theory of Law, 46 WM. \& MARY L. REV. 1915, 1917 (2005) (citing, inter alia, Gregory S. Alexander, Comparing the Two Legal RealismsAmerican and Scandanavian, 50 AM. J. COMP. L. 131, 131 (2002); Brian Leiter, Rethinking Legal Realism: Toward a Naturalized Jurisprudence, 76 TEX. L. REV. 267, 267-68 (1997); and Joseph W. Singer, Legal Realism Now, 76 CAL. L. REV. 465, 467 (1988)). Intriguingly, Green himself notes, "This is my most cited article (although usually just for my statement that people have said 'we are all legal realists now' so often that it has become a cliché to call it a 'cliché').” LEGAL REALISM, http://msgre2.people.wm.edu/Legal\%20Realism.html [https://perma.cc/3TJN-5K5R] (providing commentary on Green's articles on legal realism).

2. Wilkie v. Auto-Owners Ins. Co., 664 N.W.2d 776 (Mich. 2003).

3. Rory v. Continental Ins. Co., 703 N.W.2d 23 (Mich. 2005).

4. Ward and Wilkie died as a result of the accident. Wilkie, 664 N.W.2d at 778.

5. Id. at 781 (emphasis added).

6. Id. 
Wilkie's estate and Frank received and split evenly $\$ 50,000$ from Ward's insurance policy and claimed that Auto-Owners' owed each of them an additional $\$ 75,000$ under Wilkie's underinsured motorist coverage. ${ }^{7}$ The Michigan Supreme Court rejected this argument, noting that the "total limit" of all bodily injury liability policies available to Ward was $\$ 50,000$, and that the policy unambiguously prohibited increasing Auto-Owners' liability simply because more than one person was injured by the underinsured motorist. ${ }^{8}$ As a consequence, AutoOwners' policy unambiguously required each injury claim to subtract the total limit of Ward's policy, not the amount actually received by each injured party. To do otherwise would effectively increase AutoOwners' liability because two claims were brought rather than one, thus contravening the number of injured persons limitation.

Wilkie is an outstanding case, from a teaching perspective, because it forces students to parse complex insurance-contract language that runs contrary to what we would expect in the absence of such limitations. Moreover, at least in my experience, law students as a population tend towards arithmophobia or at least toward a mental laziness that causes their eyes to glaze over whenever the judicial reasoning requires complex operations and word problems such as parsing text and determining whether the language better fits " $\$ 100,000$ - $\$ 50,000$ " or “ $\$ 100,000$ - $\$ 25,000$." Wilkie is a difficult case, but it pays off significantly in pedagogical dividends.

Even more than teaching careful reading, complex analysis, and an understanding that contract language is not necessarily ambiguous merely because it is complex, Wilkie is also instrumental in kicking off Michigan's sharp turn toward neo-formalist jurisprudence regarding contract interpretation. Specifically, the Court of Appeals in $W_{i l k i e^{9}}$ squarely addressed and rejected Michigan's use of the Legal Realist reasonable expectations doctrine:

This approach, where judges divine the parties' reasonable expectations and then rewrite the contract accordingly, is contrary to the bedrock principle of American contract law that parties are free to contract as they see fit, and the courts are to enforce the agreement as written absent some highly unusual circumstance, such as a contract in violation of law or public policy. ${ }^{10}$

Analyzing applications of the reasonable expectations doctrine, the Court concluded that the unambiguous text of the policy deter-

7. Because there were two injured parties who received a total of $\$ 50,000$ that they split evenly (\$25,000 each), Wilkie's estate and Frank reasoned that Wilkie's underinsured motorist policy provided for limits of $\$ 100,000$ per person, up to $\$ 300,000$ per occurrence. Id.

8. Wilkie, 664 N.W.2d at 781-82.

9. Wilkie v. Auto-Owners Ins. Co., 629 N.W.2d 86, 89-90 (Mich. 2001).

10. Wilkie, 664 N.W.2d at 782 . 
mined the scope of the insured's expectations, noting that "the rule of reasonable expectations clearly has no application when interpreting an unambiguous contract because a policyholder cannot be said to have reasonably expected something different from the clear language of the contract." ${ }^{11}$

This decision set the stage for the creation of a neo-formalist contract jurisprudence (and a rejection of legal realist doctrines previously used to rewrite unambiguous contracts). In Jackson v. State Farm Mutual Automobile Insurance Co. ${ }^{12}$ the Michigan Supreme Court again carefully parsed policy language to hold ${ }^{13}$ that an unambiguous condition precedent requiring thirty days' notice of claims was enforceable. Additionally, in Rory v. Continental Insurance Co. ${ }^{14}$ the Michigan Supreme Court likewise rejected a judge-made reasonableness limitation on notice of claims in the face of an unambiguous term requiring notice of a claim within one year of an accident. ${ }^{15}$ In the same term, Justice Young's opinion in City of Grosse Pointe Park v. Michigan Municipal Liability \& Property Pool, ${ }^{16}$ observed, with respect to parol evidence rule analysis, that courts must presume "contracting parties' intent is manifested in the actual language used

11. Id. at 787 .

12. Jackson v. State Farm Mut. Auto. Ins. Co., 698 N.W.2d 400 (Mich. 2005).

13. The court's holding in this case appears in a table decision in which the court considered the Appellee's (State Farm) Application for Leave to Appeal, vacated the court of appeals' judgment and reinstated the trial court's order of judgment "for the reasons stated in the Court of Appeals dissent." Id. That dissent-Jackson v. State Farm Mut. Auto. Ins. Co., 2004 WL 2239502, at *3-*6 (Mich. Ct. App. 2004) (Griffin, J.)-is what is described here as the opinion of the court. Some might also describe the court's action as a total judicial smack-down of the majority opinion of the Michigan Court of Appeals.

14. Rory v. Cont'l Ins. Co., 703 N.W.2d 23 (Mich. 2005).

15. See id. at 31 .

Accordingly, we hold that an unambiguous contractual provision providing for a shortened period of limitations is to be enforced as written unless the provision would violate law or public policy. A mere judicial assessment of 'reasonableness' is an invalid basis upon which to refuse to enforce contractual provisions. Only recognized traditional contract defenses may be used to avoid the enforcement of the contract provision. To the degree that [prior cases] abrogate unambiguous contractual terms on the basis of reasonableness determinations, they are overruled.

Id.

16. 702 N.W.2d 106 (Mich. 2005). Justice Young's opinion is one of two opinions by an evenly divided Court in this case. While all six justices (Justice Corrigan did not take part in the decision) held that the insurance contract at issue was unambiguous, the justices split regarding the degree of proof required to permit a court to review extrinsic evidence to determine whether the contract suffered from a latent ambiguity. The opinion by Justice Cavanaugh would have held that "the detection of a latent ambiguity unquestionably requires consideration of factors outside the policy itself. . . Therefore, extrinsic evidence is admissible to prove the existence of the ambiguity, and, if a latent ambiguity is proven to exist, extrinsic evidence may then be used as an aid in the construction of the contract." Id. at 115 (Cavanaugh, J.). 
in the contract ...."17 "The party alleging the existence of the latent ambiguity may rebut this presumption only by proving, through clear and convincing evidence, that such an ambiguity does indeed exist."18 Later cases have largely continued this court's neo-formalist approach to contract interpretation in the insurance context. ${ }^{19}$

The final reason for Wilkie's importance is that the sharp jurisprudential break-from relatively legal realist jurisprudence to a relatively neo-formalist jurisprudence - creates fertile ground for assessing the real-world benefits of the doctrines that are associated with each school. While it may be true that "we are all realists now," there is a sense in which legal realism may also have been accepted as a dominant jurisprudential paradigm more for ideological and readjustment reasons rather than for any measured improvements in the delivery of justice in contract cases. Compared to more formalist doctrines that prioritize the text of contracts, doctrines based in reasonableness necessarily increase the costs of resolution, whether that comes from additional experts to prove what is reasonable, additional discovery, increased difficulty in resolving cases through summary disposition, and so on. This variance raises the serious question of whether the cost of courts' getting in touch with legal realists' facts on the ground are worth the supposed benefits. Wilkie creates a clear field for undertaking comparative analyses to inform this debate.

17. Id. at 119 (Young, J.).

18. Id. at 124 .

19. See McDonald v. Farm Bureau Ins. Co., 747 N.W.2d 811, 818 (Mich. 2008) (refusing to judicially toll contractual notice period, holding that "the majority of this Court is of the view that we follow the law established by the lawgiver. That is, when a statute is at issue, the law is established by the Legislature, and we are compelled to follow it as written. Similarly, when a contract is at issue, the law we must follow is the unambiguous terms established by the parties to the contract.") (emphasis added); Defrain v. State Farm Mut. Auto. Ins. Co., 817 N.W.2d 504 (Mich. 2012) (affirming that Jackson v. State Farm Mutual Automotive Insurance Co., 698 N.W.2d 400 (Mich. 2005), constitutes binding precedent and rejecting public policy arguments against enforcement of contractual notice period). 
Understated Elegance: Wood v. Lucy, Lady Duff-Gordon

\section{SCOTT J. BURNHAM*}

Why is Wood v. Lucy, Lady Duff-Gordon ${ }^{1}$ the best case ever? It is an underdog story, written succinctly and elegantly. It was a gamechanger for contract law. It produces satisfying moments in the classroom, and it only adds to the pleasure that the colorful defendant was depicted in a hit movie. ${ }^{2}$

You know the facts - or do you? One of the pleasures of teaching the case is to see if students can home in on the most important fact-the language of the contract. Lucy gave Wood the exclusive right to use her name for endorsements, and in return he promised her "one-half of 'all profits and revenues' derived from any contracts he might make." After receiving a better offer, she sought to get out of the contract. Her lawyers went over it with their flinty eyes and concluded, "Aha! Wood may well have promised you half the profits from contracts he might make, but he didn't promise to make any contracts! Therefore, the contract is illusory-it lacks consideration!" No wonder lawyers are depicted in popular culture as crafty devils.

Wood had quite an uphill battle to defeat this claim. True, Lucy's motion to dismiss was denied in the trial court. ${ }^{4}$ But on appeal, Lucy secured reversal by a vote of $5-0 !^{5}$ The appellate division opinion is a remarkable example of legal formalism, but you cannot say it is logically erroneous. The fact is, you can search the contract high and low for a promise by Wood, but you will not find it.

In the court of appeals, however, the great Benjamin Cardozo found a promise and persuaded three of his colleagues that it was there in order to squeak out a 4-3 victory for Wood in the final game of the series. ${ }^{6}$ What Judge Cardozo found was "a promise to use reasonable efforts to bring profits and revenues into existence." Curiously, the dissenters remained silent and did not rant that this opinion is the end of civilization as we know it, or at least the end of contract law as we know it, as they did approximately three years later

* Curley Professor Emeritus, Gonzaga University School of Law.

1. Wood v. Lucy, Lady Duff-Gordon, 118 N.E. 214 (N.Y. 1917).

2. TITANIC (Paramount Pictures 1997).

3. Wood, 118 N.E. at 214.

4. Wood v. Lucy, Lady Duff-Gordon, 177 A.D. 624 (N.Y. App. Div. 1917).

5. Id.

6. No doubt this is another example of what Gilmore called Cardozo's delight in "weaving gossamer spider webs of consideration." GRANT GILMORE, THE DEATH OF CONTRACT 69 (2d ed. 1995).

7. Wood, 118 N.E. at 215. 
in reaction to Judge Cardozo's even more artful reasoning in Ja$c o b \&$ Youngs, Inc. v. Kent. ${ }^{8}$

One cannot entirely disagree with the dissenters, for Judge Cardozo himself admitted that the promise was missing, asserting that it could be supplied because of policy: "The law has outgrown its primitive stage of formalism when the precise word was the sovereign talisman, and every slip was fatal. It takes a broader view today." He concluded with the elegant explanation that "[a] promise may be lacking, and yet the whole writing may be "instinct with an obligation,' imperfectly expressed." 10

Who could supply that more perfectly expressed obligation? None other than Judge Cardozo! But our dissenting friends should be quick to protest, "Hey, wait a minute! Contracts are for the parties to make, not for the courts to make." Of course that is true, but Judge Cardozo reminds us that the parties did make an agreement, just not a complete one. How do we know how the parties wanted that agreement to be completed? The answer lies in the context; things don't happen in a vacuum. In this case, the context was a business setting where each party intended to use the other for their own material gain-which is exactly what our economist friends tell us contracting is all about. Given that the parties tried to make a contract, why should the court refuse to help the parties achieve that goal? Contract law thus becomes a facilitator rather than a regulator by filling in the omitted terms, clarifying the badly stated ones, and generally becoming a help rather than a hindrance. ${ }^{11}$ Thus was contract law brought kicking and screaming into the twentieth century.

How marvelous is the case as a pedagogical tool. Students work hard to find the issue - and are rewarded by the "aha! moment" of discovery. While the policy arguments are not quite as divisive as in other cases, discussion helps the formalists and the facilitators see each other's points of view. And procedurally, the case illustrates the art of motion practice. It slowly dawns on students that after the case has

8. Jacob \& Youngs, Inc. v. Kent, 129 N.E. 889 (N.Y. 1921). Curiously, two of the judges who sided with Judge Cardozo in Wood, McLaughlin and Andrews, switched to the other side in the equally divisive Kent (with McLaughlin writing the stinging dissent), while two of those who dissented in Lucy, Hiscock and Crane, sided with Judge Cardozo in Kent.

9. Wood, 118 N.E. at 214 .

10. Id.

11. No doubt this approach had a powerful influence on Karl Llewellyn, who initially drafted that most faciliatory of laws: Article 2 of the Uniform Commercial Code. We find an embodiment of the holding of Wood in UCC $§ 2-306(2)$ :

A lawful agreement by either the seller or the buyer for exclusive dealing in the kind of goods concerned imposes unless otherwise agreed an obligation by the seller to use best efforts to supply the goods and by the buyer to use best efforts to promote their sale. 
worked its way through the courts for years, all that has been decided is that if Wood can prove all that he alleges, he will have satisfied one element of his claim - that there was a contract. The rest-breach and, most significantly, damages-remains to be proven. But no doubt Wood is now in a position to get a nice settlement out of Lucy.

It has been suggested that some readers of the case might find that Judge Cardozo showed disdain for Lucy in his brief description of her: "The defendant styles herself 'a creator of fashions.' Her favor helps a sale."12 I am sure Judge Cardozo was no Marxist, but if this is criticism of Lucy, it may be directed at her transition from laborer to capitalist. Indeed, Lucy seems a one-woman history of the evolution of her craft, adapting it to the modern world just as Judge Cardozo had the law. She began by crafting bespoke dresses for her friends. Later, she produced each item in quantities sufficient for those who came to the store to buy them. She wrote newspaper columns to promote her products and opened a chain of stores. Next, as exemplified by the facts of the case, she marketed her name without designing the product. And finally - the reason she tried to get out of her contract with Wood-Sears Roebuck offered to put her name on massproduced goods available for home delivery. ${ }^{13}$

Lucy and Judge Cardozo thus have more in common than either could have imagined. The development of fashion marketing reflects, in many respects, the development of contracts-from the handcrafted documents fashioned by experts to today's mass-produced forms that anyone can download from the internet. And just as Lucy made fashion available to the masses, so did Judge Cardozo democratize contracts.

Finally, how many civil defendants are featured in a movie known throughout the world? The movie may not have given Lucy as much screen time as was given to the defendants in A Civil Action, but my favorite scene in Titanic is when Rose points out Lucy to Jack, snarkily commenting that "she designs naughty lingerie, among her many talents." ${ }^{14}$ As is often the case, history has the last laugh. While Lucy's name has little value as a trademark today, Benjamin Cardozo's name lives on in connection with a distinguished law school.

12. Wood, 118 N.E. at 214. See Mary Joe Frug, Re-reading Contracts: A Feminist Analysis of a Contracts Casebook, 34 AM. U. L. REV. 1065, 1084 n.66 (1985).

13. See MEREdith Etherington-Smith \& Jeremy Pilcher, The "IT" Girls: Lucy, LADY DUFF GORDON, THE COUTURIÈRE "LUCILE," AND ELINOR GLYN, ROMANTIC NOVELIST 197 (1986) (a biography of Lucy and her equally fascinating sister).

14. Titanic (Paramount Pictures 1997). Apparently, the lingerie legacy continues. See Misty White Sidell, The birth of the designer collaboration: Meet the couturier whose 1916 line for Sears sparked a modern fashion phenomenon, DALYMAIL.COM (Sept. 17, 2013, 5:53 PM), http://www.dailymail.co.uk/femail/article-2424054/Designer-collaboration-Lady-Lucile-DuffGordons-1916-line-Sears-sparked-modern-fashion-phenomenon.html. 
Why Pyeatte v. Pyeatte Might be the Best Teaching Tool in the Contracts Casebook

\section{Charles R. Calleros*}

Pyeatte v. Pyeatte, ${ }^{1}$ a 1983 decision of the Arizona Court of Appeals, combines engaging facts with layers of legal analysis, making it one of the best teaching tools in a contracts casebook.

\section{The Facts}

After their first year of marriage, H. Charles and Margrethe orally agreed that Margrethe would support H. Charles through law school, after which he would support Margrethe while she obtained her master's degree. ${ }^{2}$ Their agreement was not conditioned on their remaining married. ${ }^{3}$

After H. Charles obtained his law degree with Margrethe's support, but before Margrethe commenced her master's program, $\mathrm{H}$. Charles announced his desire for a divorce, which they obtained in 1979. They had little community property to divide, and Margrethe declined to seek an award of spousal maintenance. ${ }^{4}$

When $\mathrm{H}$. Charles failed to support Margrethe in pursuing her master's degree, Margrethe sued and obtained judgment in the trial court for $\$ 23,000$ on her contract claim. ${ }^{5}$ The court of appeals reversed, finding the contract insufficiently definite to enforce ${ }^{6}$ but it nonetheless remanded for calculation of restitution interest on Margrethe's claim for quasi-contract. ${ }^{7}$

\section{Preliminary Matters}

The term "quasi-contract" must be puzzling to students. The opinion begins helpfully by equating quasi-contract with a constructive or implied-in-law contract:

Contracts implied-in-law or quasi-contracts, also called constructive contracts, are inferred by the law as a matter of reason and justice from the acts and conduct of the parties and circumstances surrounding the transactions ... and are imposed for the purpose

\footnotetext{
* Professor of Law, Sandra Day College of Law at Arizona State University.

1. Pyeatte v. Pyeatte, 661 P.2d 196 (Ariz. Ct. App. 1983).

2. Id. at 199 .

3. Id.

4. Id.

5. Id.

6. Id. at 200-01.

7. Id. at 207-08.
} 
of bringing about justice without reference to the intentions of the parties.... ${ }^{8}$

This short passage invites students and faculty to discuss a few helpful matters. One is the precision in using "construction" to recognize an obligation based on policy when analyzing either contracts or legislation; ${ }^{9}$ this should take place only after the court has exhausted its search for joint or collective intent through a process of "interpretation." 10 Accordingly, a "constructive contract" is one that is constructed from legal policy, as contrasted with a conventional contract that implements the intentions of the parties. From this definition, it is another short leap for students to see "constructive contract" as synonymous with "implied-in-law" contract-one that is implied from legal policy rather than from facts reflecting contractual intent.

The Pyeatte opinion expands this discussion to clarify the distinction between a conventional contract (express or implied) and a quasi-contract:

An implied-in-fact contract is a true contract, differing from an express contract only insofar as it is proved by circumstantial evidence rather than by express written or oral terms. . . . In contrast, a quasi-contract is not a contract at all, but a duty imposed in equity upon a party to repay another to prevent his own unjust enrichment. The intention of the parties to bind themselves contractually in such a case is irrelevant. ${ }^{11}$

This clear and concise exposition in Pyeatte enables students to see that a "quasi-contract" owes nearly as much to tort theory as to contract. Like promissory estoppel, and unlike the doctrine of consideration, it implements equitable principles to prevent injustice. ${ }^{12}$ Students should warm up to this search for justice after their immer-

8. Id. at 202 (quoting John A. Artukovich \& Sons v. Reliance Truck Co., 614 P.2d 327,329 (Ariz. 1980)).

9. See, e.g., Penn Mut. Life Ins. Co. v. Oglesby, 695 A.2d 1146, 1149-50 (Del. 1997) (invoking the doctrine of contra proferentem to encourage the drafting party to avoid ambiguities and provide clear notice to the other party about contractual rights and obligations); see also Bell v. United States, 349 U.S. 81, 83-84 (1955) (applying the rule of lenity in construing ambiguous criminal statute); United States v. Otherson, 637 F.2d 1276, 1285 (9th Cir. 1980) (noting that a court should rely on a rule of construction only if the "statute's language, structure, purpose, and legislative history leave its meaning genuinely in doubt").

10. Smith v. Smith, 748 N.W.2d 258, 259 n. 1 (Mich. Ct. App. 2008), appeal denied, 769 N.W.2d 591 (Mich. 2008).

11. Pyeatte, 661 P.2d at 203.

12. Id. Compare Ricketts v. Scothorn, 77 N.W. 365, 367 (Neb. 1898) (applying early form of promissory estoppel to avoid the "grossly inequitable" result if a promise, after foreseeably inducing reliance, were unenforceable for lack of consideration), with Batsakis v. Demotsis, 226 S.W.2d 673 (Tex. Civ. App. 1949) (consideration doctrine was not concerned with the gross imbalance in a promise to exchange foreign currency worth $\$ 25$ in exchange for a promise to repay $\$ 2,000$ plus interest). 
sion in a cold and rather unforgiving bath of consideration and mutual assent. ${ }^{13}$

\section{H. Charles's Unjust Enrichment}

Ironically, the express agreement figured prominently in Margrethe's claim for quasi-contract. When she enriched $\mathrm{H}$. Charles by supporting him through law school, she was not donating her savings and the fruits of her labor; she believed that $\mathrm{H}$. Charles was contractually bound to reciprocate by supporting her while she completed her graduate study. The court of appeals reversed the trial court's enforcement of their express agreement, but the agreement nonetheless reflected Margrethe's non-donative intentions at the time of $\mathrm{H}$. Charles's enrichment. ${ }^{14}$

But just as Margrethe appeared to have cleared the hurdle for quasi-contractual relief, considerations of family law seemed to raise the bar. Marital partners constantly provide services that benefit the community, without expecting an accounting. ${ }^{15}$ Margrethe overcame the normal barriers to recovery inherent in the marital context only because of the special nature of the agreement between $\mathrm{H}$. Charles and Margrethe and the manner in which H. Charles converted Margrethe's services to his unilateral benefit. ${ }^{16}$

The bar was raised yet again by recognition that parties to a marriage dissolution normally can vindicate valid claims for restitution in their division of property. ${ }^{17}$ Margrethe's claim cleared that hurdle only because she and $H$. Charles had not accumulated sufficient property to allow for such an adjustment. ${ }^{18}$

In sum, the exceptional facts in Pyeatte helped Margrethe overcome the barriers to restitution erected in the context of marriage and dissolution of marriage. The court of appeals underscored the exceptional nature of the case by warning against reducing the marital relationship to the economic value of marital services. ${ }^{19}$

13. See, e.g., Morales v. Sun Constructors, Inc., 541 F.3d 218, 222 (3d Cir. 2008) (nonEnglish-speaking employee was bound by arbitration clause in English-language agreement provided to him, notwithstanding that a translator selected by the employer failed to translate the arbitration clause); Batsakis v. Demotsis, 226 S.W.2d 673 (Tex. Civ. App. 1949) (finding that even grossly imbalanced bargained-for exchange can satisfy the consideration requirement).

14. Pyeatte, 661 P.2d at 203; see also RESTATEMENT (THIRD) OF RESTITUTION AND UNJUST ENRICHMENT $§ 31$ (AM. LAW INST. 2011).

15. Pyeatte, 661 P.2d at 203.

16. Id. at $203,206-07$.

17. Id. at $203-07$.

18. Id. at 199, 204-07.

19. Id. at 207. 


\section{Ending with a Conundrum}

The court of appeals remanded for determination of Margrethe's restitution interest, ${ }^{20}$ adding the familiar maxim that Margrethe's expectation interest should form a ceiling. ${ }^{21}$ For example, if Margrethe had expected to earn a master's degree in two or three semesters at a local college, her expectation of support could be significantly less in value than the support $\mathrm{H}$. Charles received through three years of law school. Her expectation interest could form a relatively low ceiling on restitution interest.

Ironically, the court of appeals rejected enforcement of the express contract precisely because $\mathrm{H}$. Charles's promise was too indefinite to permit calculation of expectation interest. In the wake of this ruling, how could the trial court appropriately designate a ceiling? If expectation interest could be calculated to establish a ceiling on restitution, why not to enforce the promise?22 The opinion of the Court of Appeals does not discuss this conundrum, leaving readers with an entertaining and thought-provoking puzzle. ${ }^{23}$

\section{Conclusion}

Pyeatte v. Pyeatte, with judicious editing, is one of the best in my list of assigned cases. It is engaging and informative, and its layers of analysis provide students with ample intellectual stimulation. It blends family law issues with contract law and reveals a side of contract law that departs from the conventional bargained-for exchange.

20. Id. at 208 .

21. Id. at 207 .

22. Of course, if the promise were enforceable and the expectation interest sufficiently certain to calculate, then it would make perfect sense to set the expectation interest as a ceiling, and to hold the claimant to her bargain. See RESTATEMENT (THIRD) OF RESTITUTION AND UNJUST ENRICHMENT § 2(2) (AM. LAW INST. 2011) ("A valid contract defines the obligations of the parties as to matters within its scope, displacing to that extent any inquiry into unjust enrichment.").

23. See Pyeatte, 661 P.2d at 207. 
Kingston v. Preston (and Goodisson v. Nunn, sort of)

\section{LARRY T. GARVIN*}

Why Kingston v. Preston ${ }^{1}$ Because, more than any other judicial decision, Kingston v. Preston made effective the bilateral executory contract-a concept called by one scholar "the most beautiful notion that ever appeared in contract law."

It accomplished this by giving rise to constructive conditions of exchange, in particular the constructive condition concurrent. To appreciate the significance of this move requires a bit of history. In the earliest days of assumpsit, the courts conclusively presumed that mutual promises were dependent. But from the late seventeenth century until the time of Kingston, the courts abandoned this presumption and ultimately presumed that contractual promises were mutual and independent. ${ }^{3}$ Each party could therefore sue the other without proving, or even alleging, that it had itself performed or tendered performance. ${ }^{4}$

Independence wasn't illogical, given the assumptions of the time. If a future act is the consideration, then that act must first be performed. If a future promise is the consideration, then the existence of the promise will suffice; the promise is present, even if the performance is yet to come..$^{5}$ Not illogical, but not practical in a market economy. Much of the point of a bilateral executory contract is linking one promise to another. But it is also important that these links be severable; otherwise, one party must essentially give credit to the other by performing under its own contract, even if it does not receive the performance of the other and may have to sue for the promised benefit. It is true that a party subject to a breach might abandon its own performance, but by doing so it would itself be in breach. Moreover, until the nineteenth century set-off and counterclaims were not

* Lawrence D. Stanley Professor, Michael E. Moritz College of Law, The Ohio State University.

1. (1772) 99 Eng. Rep. 437 (cited in argument in Jones v. Barkley (1781) 99 Eng. Rep. 434, 437-38, 440); (1772) 98 Eng. Rep. 606, 606-08). The two reports differ substantially.

2. II Thomas ATKINS Street, The Foundations of LEGAL LiaBiLity 60 (1906).

3. See, e.g., Ughtred's Case, (1591) 77 Eng. Rep. 425, 426 (C.P.). See generally Clinton W. Francis, The Structure of Judicial Administration and the Development of Contract Law in Seventeenth-Century England, 83 COLUM. L. REV. 35, 102-16, 121-27 (1983).

4. See, e.g., Nichols v. Raynbred (1615) 80 Eng. Rep. 238, 238 (contract to sell a cow for fifty shillings; holding that the seller need not aver delivery in order to sue on promise to pay).

5. In the words of Professor Simpson, the courts of the time might have asked "Why should performance be averred; the plaintiff has satisfied the requirements in assumpsit by showing promise, consideration, and breach-what else is needed?" A.W. BRIAN SIMPSON, A HISTORY OF THE COMMON LAW OF CONTRACT 463 (1975). 
available in Anglo-American courts, requiring two separate actions if both parties were to seek satisfaction. ${ }^{6}$

But the presumption of independence was just that: only a presumption. Clear enough contractual language could overcome it and make the promises dependent. ${ }^{7}$ Whether particular language in fact did soon became the subject of a large and tangled jurisprudence. In the words of one early commentator:

So refined and subtle are the distinctions on which [the courts] have proceeded, that it is almost impossible to draw from them any reasons, as a guide to discover with certainty whether covenants are dependent or not. Some of the determinations have incurred the censure of outraging common sense; others of deciding contrary to the real meaning of the parties, and the true justice of the case. ${ }^{8}$

The result was frustrating but apparently intractable. In 1744, a leading commercial judge observed that, were it a question of first impression, he would allow a defendant to assert the plaintiff's nonperformance as a defense-"but this has been so often determined otherwise, that it is too late now to alter the law in this respect." But then came Lord Mansfield, who, "with more courage and less regard for precedent, in the case of Kingston v. Preston, disregarded the prior decisions, and enumerated certain principles which became the foundation for our modern conditions implied in law."10

As a reminder, Kingston arose from the plaintiff's promise to serve essentially as an apprentice in exchange for the defendant's agreement to sell him his business on credit after the apprenticeship ended. ${ }^{11}$ As part of the contract, the plaintiff agreed that he would provide security sufficient to satisfy the defendant. After the plaintiff performed the covenanted work, the defendant declined to sell the business. The plaintiff brought an action in debt, and the defendant pleaded that the plaintiff did not offer sufficient security. The case turned on whether the covenants were dependent or independent. If they were dependent, then the plaintiff's right to purchase the business would not arise until he provided or tendered sufficient security. If they were independent, then the plaintiff's failure to provide the

6. Francis, supra note 3, at 82-83. See generally William H. Loyd, The Development of Set-Off, 64 U. PA. L. REV. 541 (1916).

7. The leading case to this effect was Thorp v. Thorp (1701) 88 Eng. Rep. 1448.

8. Thomas Platt, A PRActical Treatise on the LAW of Covenants 71-72 (1829). Platt also referred to this doctrine as "quaint technicalities," consisting of "nice and obscure distinctions." Id. at 72,78 .

9. Thomas v. Cadwallader (1744) 125 Eng. Rep. 1286, 1289.

10. Clarence D. Ashley, The LaW of ConTracts $\S 68$, at 188 (1911).

11. Kingston v. Preston (1772) 99 Eng. Rep. 437, 437 (cited in argument in Jones $v$. Barkley (1781) 99 Eng. Rep. 434). 
security could give rise to a cross-action for breach but would not serve as a defense to the cause of action. The problem of credit was especially acute here, because the plaintiff was admitted to be worth nothing. Kingston was thus a good test case for those who favored dependent covenants.

Lord Mansfield began by laying out the three types of covenants; mutual and independent, conditional and dependent, and concurrent. Which might be present turned on "the evident sense and meaning of the parties." 12 Here "it would be the greatest injustice if the plaintiff should prevail," because it was "the essence of the agreement ... that the defendant should not trust to the personal security of the plaintiff, but, before he delivered up his stock and business, should have good security ... . The giving such security, therefore, must necessarily be a condition precedent." ${ }^{13}$

In Kingston the court abandoned the strained and convoluted attempts to find conditions in the language of the parties, choosing instead the more forthright decision to imply a term. As a corollary, Lord Mansfield brushed aside - without even a mention-the presumption of independence, which would normally have applied because of the lack of an express condition, and therefore the attendant credit risk. By doing so, he went far toward the modern treatment of mutual promises as bilateral, rather than as a brace of unilateral promises.

Revolutionary? That certainly has been the consensus. Judges of the time quickly accepted (a) the shift away from independent promises and (b) the use of implied conditions, generally citing to Kingston as, in the words of one, the "first strong authority" favoring dependence. ${ }^{14}$ The same goes for learned commentators. Here is Langdell: "[T]he whole doctrine of the implied dependency of mutual covenants and promises is a modern one. Indeed, not a trace of it

12. Id. at 438 .

13. Id. The report in Lofft is even more vigorous, bordering on incoherent:

It would be the most monstrous case in the world, if the argument on the side of [the plaintiff] was to prevail. It's of the very essence of the agreement, that the defendant will not trust the personal security of the plaintiff. A Court of Justice is to say, that by operation of law he shall, against his teeth. He is to let him into his house to squander every thing there, without any thing to rely on by what he has absolutely refused to trust.

Id. at 608. Note the special emphasis on credit and, even to a degree, moral hazard.

14. Glazebrook v. Woodrow (1799) 101 Eng. Rep. 1432, 1439; see also id. at 1441 (referring to "the rule first laid down in Kingston v. Preston"). This was true as well in the United States, where the approach in Kingston quickly took hold. See, e.g., Bank of Columbia v. Hagner, 26 U.S. (1 Pet.) 455, 464-65 (1828); Goodwin v. Lynn, 10 Fed. Cas. 624, 625 (Cir. Ct. Pa. 1827) (No. 5,553); Green v. Reynolds, 2 Johns. 207, 209 (N.Y. Sup. Ct. 1807); Bradford v. Gray, 11 Tenn. (3 Yer.) 463, 466 (1832). 
is to be found prior to the time of Lord Mansfield." ${ }_{15}$ And Williston: "[I]n spite of three centuries of opposing precedents, Lord Mansfield thirty years [after Thomas $v$. Cadwallader] decided that performance of one covenant might be dependent on prior performance of another, though there was no express condition." 16 And Holdsworth: "With the adoption of this changed attitude by the courts of law, the modern history of this branch of the law begins." 17

Really? First, there is reason to believe that Kingston reflected then-current practice, whatever the case law might have said. ${ }^{18}$ And, there were cases that presaged Kingston. In Turnor v. Goodwin, ${ }^{19}$ for example, Turnor, who had procured a judgment against a third party, agreed not to execute on the judgment if Goodwin would agree to pay the amount due upon Turnor's request. Turnor agreed as well to assign the judgment to Goodwin. Turnor sought payment; Goodwin pleaded that Turnor had not assigned the judgment; Turnor replied that he was ready to do so. A court of 1713 might have been expected to apply the presumption of independence and hold that Goodwin's argument was irrelevant. But not the court in Turnor. The court stated that there were difficulties with making either performance a condition precedent of the other. ${ }^{20}$ Its solution: "[T]his assignment shall neither precede nor wait, but shall accompany the payment, and both to be done at the same time." ${ }^{21}$ In other words, a constructive condition concurrent. ${ }^{22}$

Just one more little problem. Kingston did not itself rest on the existence of a constructive condition concurrent. Lord Mansfield found a constructive condition precedent, not a constructive condition concurrent. Not until the time of Lord Kenyon, Lord Mansfield's suc-

15. C.C. LANGDELl, A Summary OF THE LAW OF CONTRACTS 177 (2d ed. 1880).

16. II SAMUEL WILLISTON, THE LAW OF CONTRACTS $\$ 817$, at 1566-67 (1921).

17. VIII SiR WILLIAM HOLDSWORTH, A HiSTORY OF ENGLISH LAW 75 (2d ed. 1937). See also, e.g., EdWARD AVERY HARRIMAN, ElEMENTS OF THE LAW OF CONTRACT 153 (1896) ("The doctrine of implied dependency was introduced by Lord Mansfield in 1773."); Michael G. Bridge, Discharge for Breach of the Contract of Sale of Goods, 28 MCGILL L.J. 867, 87374 (1983) ("[T]t was not until Kingston v. Preston that this link between formation and performance can be said to have been decisively made. . . Lord Mansfield in Kingston v. Preston swept aside the language of formalism evident in the earlier cases and extended the inquiry to the implied intention of the parties."); Edwin W. Patterson, Constructive Conditions in Contracts, 42 CoLUM. L. REV. 903, 908 (1942) (“[N]early two centuries elapsed after the recognition that a promise is consideration for a promise before the general doctrine of mutual dependency of promises was established.").

18. See, e.g., TARIQ A. BALOCH, UNJUST ENRICHMENT AND CONTRACT 102-03 (2009).

19. (1713) 92 Eng. Rep. 796.

20. Id. at 796 .

21. Id. at 798. See also Merrit v. Rane (1721) 93 Eng. Rep. 633, 635, 1 Strange 458, 460 (following Turnor).

22. For more instances of the recognition of dependent promises, see William M. McGovern, Jr., Dependent Promises in the History of Leases and Other Contracts, 52 TUL. L. REV. 659 (1978). 
cessor, was the issue squarely raised. In Goodisson v. Nunn, ${ }^{23}$ Lord Kenyon found constructive conditions concurrent in a simple contract to sell real property, indeed observing that the case was "extremely clear, whether considered on principles of strict law or of common justice." 24

All of this raises two questions. If Kingston $v$. Preston was not the first decision to find bilateral executory covenants to be dependent, and if it was not the first to hold that an executory contract contains constructive conditions of exchange, then why is it great? And why do we not refer instead to Lord Kenyon's opinion in Goodisson v. Nunn, which actually did find a constructive condition concurrent?

First, it is of little moment that a few stray cases anticipated some aspects of Kingston. Every old volume of case reports inters its mute inglorious Hadley. ${ }^{25}$ And early cases, finding dependence in the language of a bilateral contract, do not undercut Lord Mansfield's accomplishment-leaving the world of strained interpretation and resorting instead to implied conditions. Nevertheless, the flat assertions of the commentators above want tempering. Perhaps Street will stand for others; after Turnor "it remained for Lord Mansfield subsequently to give shape and consistency to the law of the whole subject and to place it upon a firm and satisfactory basis." ${ }^{26}$

And perhaps Kingston is great in the same way that Allegheny College is great-not so much because of what it held as what it led to. Allegheny College rested on consideration rather than promissory estoppel. But before Judge Cardozo laid out his consideration analysis, he hinted that promissory estoppel might provide an alternative means of finding Mary Yates Johnston's promise enforceable. Similarly, Lord Mansfield didn't actually hold that the contract between Kingston and Preston contained constructive conditions concurrent. But he laid out the types of constructive conditions, sweeping aside the mass of old cases lamented by Chief Justice Willes in Thomas $v$. Cadwallader and made cases like Goodisson v. Nunn possible.

23. (1792) 100 Eng. Rep. 1288.

24. Id. at 1289. See George P. Costigan, JR., The Performance of Contracts: A SUMMARY OF CONDITIONS IN CONTRACTS AND IMPOSSIBILITY OF PERFORMANCE 34-35 n.67 (1911) (after referring to Kingston: "But Goodison v. Nunn . . . seems to have been the first case actually implying [constructive conditions concurrent].”). See also, e.g., Morton v. Lamb (1797) 101 Eng. Rep. 890, 893 (Kenyon, C.J.) (when both sides are to perform at the same time, "[s]peaking of conditions precedent and subsequent in other cases only lead[s] to confusion.”).

25. Hadley v. Baxendale (1854) 156 Eng. Rep. 145. See, e.g., McAlpin v. Lee, 12 Conn. $129,132-33$ (1837) (holding that there is no recovery for consequential damages unless the loss naturally resulted from the breach); Armstrong v. Percy, 5 Wend. 535, 538 (N.Y. Sup. Ct. 1830) (finding that damages are recoverable only if they naturally arise from breach or if specially proved).

26. II STREET, supra note 2, at 137-38; see also S.J. STOLJAR, A HISTORY OF CONTRACT AT COMMON LAW 157 n.45 (1975) (agreeing with Street). 
We might also contrast the authors of Kingston and Goodisson. Lord Mansfield was Lord Mansfield, while Lord Kenyon was, well, Lord Kenyon. Lord Mansfield was learned, eloquent, imaginative, convivial, and generous; Lord Kenyon was poorly educated, inarticulate, hidebound, irritable, and penurious. ${ }^{27}$ Lord Kenyon's opinions tended toward bluff ipse dixit rather than fine-spun analysis, and he almost invariably championed the traditional over the venturesome. ${ }^{28}$ He overturned a good many of Lord Mansfield's opinions, and often spoke slightingly of Lord Mansfield's more venturesome efforts. Even had Goodisson not followed in Kingston's wake, one would still expect Lord Mansfield's opinion to attract greater attention. ${ }^{29}$

In addition, Kingston, unlike Goodisson, is the source of a huge body of modern contract law. Consider the principal objection to dependency: that by preventing full performance, or by refusing to accept performance that varied even trivially from that promised, the promisee could forever refrain from performing its promise. This would shift the credit risk to the party performing first and, in modern terms, would subject it to the risk of opportunistic behavior by the other party. Lord Mansfield provided the modern answer to that problem six years later in Boone v. Eyre. ${ }^{30}$ There he held that where mutual covenants "go only to a part [of the consideration], where a

27. For a brilliantly corrosive exercise in damning with faint praise, see 4 JOHN CAMPBELL, THE LIVES OF THE CHIEF JUSTICES OF ENGLAND 1 (1881), which contains these epithets and many, many more. Even more balanced accounts tend to be sparing with praise. See, e.g., PUBLIC CHARACTERS OF 1799-1800, at 559-61 (1799); 1 WILLIAM C. TOWNSEND, THE LIFE OF LORD KENYON, in THE LIVES OF Twelve EMINENT Judges OF THE LAST AND OF THE PRESENT CENTURY 33 (1846); Douglas Hay, Kenyon, Lloyd, First Baron Kenyon, OXFORD DICTIONARY OF NAT'L BIOGRAPHY (2009), https://doi.org/10.1093/ref:odnb/15431 [https://perma.cc/E2M2-FHEE]; Lord Kenyon, 19 J. JURIS. 464, 475 (1875) ("We can pardon his want of brilliancy, but we are repelled by his intense narrowness.").

28. In the words of one scholar, he was "no reformer," and "very much the supreme legal technician rather than an innovator." Anthony H. Manchester, Kenyon, Lloyd (Lord Kenyon), in BIOGRAPHICAL DiCTIONARY OF THE COMMON LAW 294, 296 (A.W.B. Simpson ed., 1984).

29. One might then ask why Lord Kenyon, far from reversing Kingston v. Preston, extended it in Goodisson and several subsequent cases. To speculate, it may be, as Baloch has suggested, that Kingston was part of a more general trend toward commercial realism. BALOCH, supra note 18. Certainly, Lord Kenyon had no doubts-not that he ever did:

The old cases, cited by the plaintiffs counsel, have been accurately stated; but the
determinations in them outrage common sense. I admit the principle on which they
profess to go: but I think that the [j]udges misapplied that principle.... I am glad to
find that the old cases have been over-ruled; and that we are now warranted by
precedent as well as by principle to say that this action cannot be maintained.

Goodisson v. Nunn (1792) 100 Eng. Rep. 1288, 1289-90. It may also be worth noting that Lord Kenyon did not refer to Kingston v. Preston in his judgment. That was left for Justice Buller to hammer home. Id. at 1290. Perhaps not by coincidence; Lord Mansfield had wanted Justice Buller, rather than Lord Kenyon, to succeed him, and indeed delayed his retirement in hopes of persuading the political authorities to do just that. See NORMAN S. Poser, LoRD MANSFIELD: JUSTICE IN THE AGE OF REASON 386-88 (2013).

30. Boone v. Eyre (1777) 126 Eng. Rep. 160, 160. 
breach may be paid for in damages, there the defendant has a remedy on his covenant, and shall not plead it as a condition precedent." ${ }^{31}$ This idea - that part performance might prevent the promisee from asserting a constructive condition, thus relegating him to an action for breach-soon was explained as treating the condition as satisfied when a material part of the agreement had been performed. ${ }^{32}$ Behold the modern doctrine of material breach.

We might go a step further. As one scholar has observed:

[W] here one party repudiated his contractual obligations ... the other party had a defence and an excuse for non-performance. His defence was that the defaulting party had not complied with the [constructive] condition precedent to the innocent party's obligation to perform. And because the defaulting party could not enforce the contract, the innocent party could treat himself as excused from further performance. ${ }^{33}$

So the law of anticipatory repudiation rests on the constructive conditions that arose from Kingston. And consider the law of frustration. In the United States, it is generally treated as an offshoot of mistake. But in the United Kingdom, the frustration defense was rooted in an implied condition that a particular thing, or state of things, would continue to exist. ${ }^{34}$ And it is in Kingston v. Preston that we see the basis for the law of implied conditions..$^{35}$

But all this is to paint the lily. Constructive conditions, in particular the constructive conditions of exchange, are essential to the common law of bilateral contracts. Kingston v. Preston is the basis for the common law of constructive conditions. That is greatness enough, I think.

31. Id.

32. Glazebrook v. Woodrow (1799) 101 Eng. Rep. 1436, 1441. See generally BALOCH, supra note 16 , at 104-22.

33. Francis Dawson, Metaphors and Anticipatory Breach of Contract, 40 CAMBRIDGE L.J. 83,89 (1981).

34. See, e.g., Hirji Mulji v. Cheong Yue S.S. Co. [1926] 134 LT 737, 740 (P.C.); R. G. McElroy \& Glanville Williams, The Coronation Cases-I, 4 MOD. L. REV. 241, 242, 252-53 (1941),

35. On the connection between implied conditions and the law of impossibility and frustration, see 6 ARTHUR LINTON CORBIN, CORBIN ON CONTRACTS $\S \S 1320-1322$ (1962); John Henry Schlegel, Of Nuts, and Ships, and Sealing Wax, Suez, and Frustrating Things-The Doctrine of Impossibility of Performance, 23 RUTGERS L. REV. 419, 421-23 (1969); Cf. J. H. Baker, Contract: Construction of “Condition," 32 CAMBRIDGE L.J. 196, $197-$ 98 (1973). 
Combating Limits of the Case Method with Quake Construction, Inc. v. American Airlines, Inc.

\section{NADELLE GROSSMAN ${ }^{*}$}

In my view, a good contracts case contains a clear holding from the court, serves as a useful guide to future contracting parties, and supports important policies furthered by contract law. But a great contracts case is one that is also useful pedagogically; one that helps students understand and work with the law of contracts.

There are challenges, however, to effectively educating law students using cases taught through the case method-the chief pedagogical approach to first-year contracts classes. ${ }^{1}$ Importantly, as the Carnegie Report on Educating Lawyers identifies, the case method fails to capture the complexities of the people and circumstances in disputes. ${ }^{2}$ Instead, the excerpted appellate opinions included in textbooks typically present only the narrow facts relevant to the issue on appeal. $^{3}$

This limitation is especially troublesome for contracts classes for several reasons. ${ }^{4}$ First, the concise factual recitation included in the typical appellate opinion generally omits the parties' goals for entering the contract. This omission prevents readers from understanding

* Associate Professor of Law, Marquette University Law School.

1. See William M. Sullivan et al., Educating Lawyers: Preparation for the PROFESSION OF LAW 5 (2007) [hereinafter CARNEGIE REPORT] (noting that in comparison to other professional fields, legal pedagogy is remarkably uniform across variations in schools, and with the exception of a few schools, the first-year curriculum relies heavily on the case dialogue teaching method); Carol L. Chomsky, Casebooks and the Future of Contracts Pedagogy, 66 HASTINGS L.J. 879, 879 (2015) ("Contracts teachers have long relied on the casebooks they adopt to help them build and shape both the content and the pedagogy of their contracts classes.").

2. See CARNEGIE REPORT, supra note 1, at 6 (noting that "the task of connecting these conclusions with the rich complexity of actual [fact] situations . . . involv[ing] fulldimensional people" can be lost when using the case method).

3. Those opinions typically also present the facts as if they were undisputed. See Todd D. Rakoff \& Martha Minow, A Case for Another Case Method, 60 VAND. L. REV. 597, 601 (2007) (noting that "[a]ppellate opinions hide, rather than display, how 'facts' are constructed," and consequently, "do little to equip students to navigate overlapping and diverging witness accounts, gaps in forensic material, disputes over significance levels in statistical studies, or the influence of a narrative frame").

4. There are also concerns with this acontextual presentation of cases not specific to contract law. One concern is that it suggests that facts are fixed. In fact, facts are often disputed by the parties. One reason for the absence of "fixed" facts is because the parties' perceptions of facts are shaped by their cultures, values, prior exchanges with their contractual counterparties, and other factors that influence how they see the world. See Terence Dunworth \& Joel Rogers, Corporations in Court: Big Business Litigation in U.S. Federal Courts, 1971-1991, 21 LAW \& SOC. INQUIRY 497, 504-05 (1996) Moreover, the acontextual presentation of facts ignores the existence of pressures that influence a party's decision to litigate. For example, “[p]arties' actions and intentions may change over time as they communicate-with the other party] [or] with agents or lawyers." Id. 
what change in the contracting parties' relationship, or in the surrounding circumstances, motivates a party to avoid its contractual obligations. Thus, without context, a student perceives a dispute as emerging out of the availability of a legal defense instead of emerging out of a party's undermined business goals or out of a desire to pursue another opportunity. ${ }^{5}$

Moreover, many contract doctrines-such as promissory estoppel and unconscionability-factor in fairness. ${ }^{6}$ However, without facts as to the parties' relationship, conduct, and surrounding circumstances, a reader struggles to justify (and professors struggle to explain) the outcomes of these decisions.

In addition, contract disputes usually raise issues under multiple legal doctrines. That is because nearly all contract law doctrines converge to answer the pivotal question: whether a party's promise is enforceable. Repeatedly presenting appellate cases that raise a narrow issue on appeal prevents law students from understanding the interwoven nature of contract law, in turn impairing their mental map of this foundational area of law.

Finally, by omitting information about contracting parties and the complexities of their situation, the case method does not support instruction of professional skills, such as how to draft a contract that completely, unambiguously, and accurately reflects the terms of the bargain. Thus, law students must develop these fundamental professional skills in workshops or in practice and connect those skills to the legal doctrine studied years before in their 1L contracts class.

Fortunately, there are some appellate cases that largely overcome these case-method limitations. One such case is Quake Construction, Inc. v. American Airlines, Inc. ${ }^{7}$

5. See Robert E. Scott, Contract Design and the Shading Problem, 99 MARQ. L. REV. 1, 11-12 (2015) (noting that a party will enter into an agreement in good faith and then subsequently breach that same agreement for self-interest reasons; a behavior that may be defined as "opportunism"); E. Allan Farnsworth, Precontractual Liability and Preliminary Agreements: Fair Dealing and Failed Negotiations, 87 CoLUM. L. REV. 217, 282 (1987) (noting that while a party may break off an agreement due to unfair dealings, mistakes, or changed circumstances, "sometimes a party ... has simply exhausted its patience and concluded that the negotiations have no [future] chance of success").

6. See Randy E. Barnett, The Richness of Contract Theory, 97 MiCH. L. REV. 1413, 1419 (1999) ("Although based in part on promissory principles, modern contract law is also tempered both within and without its formal structure by principles, such as reliance and unjust enrichment, which focus on fairness and the interdependence of parties rather than on parties' actual agreements or promises.").

7. Quake Constr., Inc. v. Am. Airlines, Inc., 537 N.E.2d 863 (Ill. App. Ct. 1989), aff'd, 565 N.E.2d 990 (Ill. 1990). In addition to combating these limitations of the case method, the concurring opinion in Quake, which promotes a shift in the law toward an implied duty to negotiate in good faith as a middle-ground between contract and no contract, introduces an opportunity to discuss the policies served by contract law, as well as the process of contract law making. 
In this case, Quake bid on a project to expand the employee facilities and automotive maintenance shop in American Airlines, Inc. (AA)'s facilities at O'Hare International Airport. ${ }^{8}$ On April 18, 1985 , Jones Brothers Construction Corporation (Jones), AA's construction manager, sent Quake a "letter of intent" (LOI) in which Jones said it "elected to award the contract" to Quake, with construction to begin the week of April 22, 1985-four days after the date of the LOI. ${ }^{9}$ The LOI also indicated that Jones authorized the work set forth in the bid documents. ${ }^{10}$ The last line of the LOI included that Jones "reserve[d] the right to cancel this letter of intent if the parties [could not] agree on a fully executed subcontract agreement."11

The parties held a preconstruction meeting on April 25, 1985-the week during which construction was to begin. ${ }^{12}$ At the meeting, Jones presented Quake as the general contractor for the project. ${ }^{13}$ But immediately afterward, AA informed Quake that its involvement in the project was terminated. ${ }^{14}$

Quake then sued to enforce the LOI, arguing that the LOI was binding because of the language that indicated Jones "had elected to award the contract" to Quake, and that Jones had authorized the work. ${ }^{15}$ Moreover, the surrounding facts indicated an intent to be bound, as Quake's performance was scheduled to begin three days after it received the LOI, which, realistically, was not enough time for the parties to finalize a formal written contract. ${ }^{16}$

Jones and AA, on the other hand, maintained that the LOI's reservation of Jones' right to cancel if the parties did not agree on a fully executed contract clearly indicated Jones' and AA's intent to not be bound by the LOI. ${ }^{17}$

There are several ways in which this appellate case overcomes the weaknesses of the case method described above.

First, the court clearly explained why Jones entered the LOI on behalf of AA - to have AA's international facilities upgraded. ${ }^{18} \mathrm{Know}$ ing AA's goal for having Jones hire Quake allows readers to explore the reason why AA wanted to avoid being bound by the LOI: it no longer wanted to expand its operations at the international termi-
8. Id. at 864 .
9. Id. at $866-67$.
10. Id. at 867 .
11. Id.
12. Id. at 864 .
13. Id.
14. Id.
15. Id. at 866-67.
16. Id. at 864 .
17. Id. at 866 .
18. Id. at 864 . 
nal. ${ }^{19}$ In other words, the depth and clarity of the facts provides a useful platform through which to demonstrate how legal doctrines are tools for a party to avoid what they ultimately view as a bad deal.

Moreover, this case shows how multiple contract law doctrines can operate together and bear on the ultimate question of whether a binding obligation was created. Specifically, in addition to a brief discussion of rules of interpretation to determine the meaning of the termination clause, ${ }^{20}$ the court explained the concept of conditions precedent: for if entry into a formal written document was a condition precedent to Jones' intent to be bound, then it would not be bound until that time. ${ }^{21}$ The court also evaluated Quake's alternative theory of recovery of promissory estoppel, explaining how a recovery under promissory estoppel, like under bargain theory, turned on the parties' intent to be bound to the LOI. ${ }^{22}$ In this way, the Quake case shows how numerous, important contract law doctrines intersect at the root question of whether a promise is enforceable, helping students create a mental map of contract law and its concepts.

Finally, Quake is an effective tool to teach law students about professional skills, such as care in drafting. Had the draftsperson been clearer about what termination actually meant in the LOI, arguably the dispute could have been avoided. ${ }^{23}$ The language of the LOI presented in this case could allow students to even redraft the provision to more clearly reflect Jones' and AA's stated intent.

19. Douglas Frantz et al., A Hitch in O'Hare Expansion, CHICAGo TrIBUNE (September 11, 1985), http://articles.chicagotribune.com/1985-09-11/news/8503010563_1_internationalterminal-international-carriers-united-airlines [https://perma.cc/F4FR-UDEG] ("Plans for a new international terminal at O'Hare International Airport have been endangered by cost overruns in the airport expansion project... . United Airlines and American Airlines . . do not want the $\$ 70$ million international terminal built because they think it would be too costly and benefit their competition.").

20. Quake Constr., Inc., 537 N.E.2d at 866.

21. Id. at 867 .

22. Id. at 868 .

23. This case also lends itself to a dialogue about the need to achieve diversity goals in contracting. It could be used to raise this topic because the bid specifications required the general contractor to include minority business enterprise, women-owned business enterprise, and equal employment opportunity goals. Such requirements can stimulate a discussion of whether a moral actor would self-impose such diversity goals. See Harry G. Prince, Contract Law Present and Future: A Symposium to Honor Professor Charles L. Knapp on Fifty Years of Teaching Law, 66 HASTINGS L.J. 871, 877 (2015) ("Professor Maute's study reveals the impact of race and politics in understanding [Quake], including the interesting interplay between legendary 'Chicago style politics' and efforts to diversify the participation of contractors on major construction projects in the city.”). 


\section{Hadley v. Baxendale: A Bayesian Analysis of the Hadley Rule}

\section{F. E. GUERRA-PUJOL ${ }^{*}$}

In contrast to my colleague Kenney Hegland, ${ }^{1}$ I write to defend Hadley $v$. Baxendale. ${ }^{2}$ Although this classic case has often been extolled for reasons of optimal information disclosure, ${ }^{3}$ I shall praise the Hadley rule on Bayesian grounds. ${ }^{4}$ But before I explain why Hadley should be included in the canon of best contracts cases ever decided, let us take a moment to recite the facts of the case and restate the substance of its famous rule. ${ }^{5}$ Let us start with the parties: the plaintiffs were the millers - they owned and operated a grain mill while the defendants were common carriers - they transported goods across land and waterways. ${ }^{6}$ One day, when the millers' sole crankshaft broke apart, they hired the defendants' firm to ship their broken crankshaft to its original manufacturer for repair. ${ }^{7}$ The carrier, however, negligently mislaid the crankshaft and delayed its delivery, causing the millers to shut down for an extended period of time (five days). ${ }^{8}$

Hadley thus poses the following fundamental remedial question: because the carrier had promised to the millers timely delivery of the crankshaft, should not the carrier be liable for the full extent of the millers' losses during their extended shutdown? The Hadley rule says "no" and is usually stated in terms of "reasonable foreseeability." In brief, a breaching party is legally liable only for economic losses that were reasonably foreseeable at the time the parties entered into their

* F. E. Guerra-Pujol teaches business law at the University of Central Florida. Thanks to Val Ricks and George Geis for their substantive comments on previous drafts of this paper and to Shannon Morris for her editiorial help.

1. See discussion infra Hegland on Hadley p. 992.

2. (1854) 156 Eng. Rep. 145; 9 Ex. 341.

3. See, e.g., Lucian Ayre Bebchuk \& Steven Shavell, Information and the Scope of Liability for Breach of Contract: The Rule of Hadley v. Baxendale, 7 J. L. ECON. \& ORG. 284 (1991); RICHARD A. POSNER, ECONOMIC ANALYSIS OF LAW 127-28 (6th ed. 2003).

4. Specifically, I shall argue in accordance with standard Bayesian decision theory that the liability rule established in Hadley is the rule that ex ante maximizes the sum of one's expected utility when one has an equal probability of being a promisor or a promisee. See, e.g., John W. Pratt, Howard Raiffa \& Robert Schlaifer, The Foundations of Decision Under Uncertainty: An Elementary Exposition, 59 J. AM. STAT. ASS'N. 353 (1964).

5. As an aside, many contract law scholars consider Hadley to be one of the most, if not the most, famous contracts case ever decided. See, e.g., Daniel P. O'Gorman, When Lightning Strikes: Hadley v. Baxendale's Probability Standard Applied to Long-Shot Contracts, 47 LOY. U. CHI. L. J. 859, 865, 865 n.25 (2016).

6. Hadley v. Baxendale (1854) 156 Eng. Rep. 145, 146.

7. Id.

8. Id. at 147 .

9. See, e.g., Lon L. Fuller \& William R. Perdue, Jr., The Reliance Interest in Contract Damages, 46 YALE L.J. 52, 85 (1936). 
contract. ${ }^{10}$ As a result, however the concept of foreseeability is defined, ${ }^{11}$ the overall effect of the Hadley rule is to limit contract damages instead of expanding them. ${ }^{12}$

I shall now proceed to argue, using standard Bayesian decision theory, why the liability rule established in Hadley is the rule that ex ante maximizes the sum of one's expected utility when one has an equal probability of being a promisor or a promisee. To see why, let us leave behind the material world of broken crankshafts and idle grain mills and infiltrate the abstract theoretical world of ethics and Bayesian decisionmaking. Specifically, if self-interested and rational actors were to choose a remedial breach of contract rule from behind a veil of ignorance, what type of contract remedy or rule would such imaginary envoys agree to ex ante; that is, in the original position? ${ }^{13}$ Although the idea of an "original position" is usually associated with John Rawls's classic work, A Theory of Justice ${ }^{14}$ this concept was first developed by the Hungarian economist John Harsanyi. ${ }^{15}$ Unlike Rawls, however, who famously argued that persons in the original position would follow a maximin strategy, ${ }^{16}$

10. Id. at 152 (or in the immortal words of Baron Alderson, who announced the decision in Hadley: "Where two parties have made a contract, which one of them has broken, the damages which the other party ought to receive in respect of such breach of contract should be such as may fairly and reasonably be considered either arising naturally, i.e. according to the usual course of things, from such breach of contract itself . ...").

11. Some contract law scholars have claimed that "reasonable foreseeability" is a logically circular test. See, e.g., Fuller \& Perdue, supra note 9, at 85.

12. To see why, consider two possible alternatives to the Hadley rule. On one extreme, we can envision a pro-victim remedial rule in which breaching promisors are always liable for all losses flowing from their breaches of contract, no matter how remote or unforeseeable such losses might be ("total liability"). On the other extreme, we can picture a probreacher rule in which promisors are never liable for any losses resulting from their breaches ("no liability").

13. I acknowledge that this conception of the original position, like Einstein's "relativity train" in the domain of physics, is physically impossible. Cf. Bruno Latour, A Relativistic Account of Einstein's Relativity, 18 SOC. STUD. SCI. 3, 7 (figure 2) (1988) (visualizing Einstein's "relativity train"). Nevertheless, just because a state of affairs is unrealistic or far-fetched (such as Rawls's original position or Einstein's train travelling at the speed of light), a thought experiment, however fanciful or contrived, can still be useful by helping us clarify our thinking or by bringing hidden assumptions to the surface. Cf. JOHN RAWLS, JUSTICE AS FAIRNESS: A RESTATEMENT 83 (2001) (describing the original position as a "thought experiment").

14. JOHN RAWLS, A THEORY OF JUSTICE (1971).

15. John C. Harsanyi, Cardinal Utility in Welfare Economics and in the Theory of Risk-Taking, 61 J. POL. ECON. 434 (1953). In his 1953 paper, Harsanyi refers to the notion of "impersonality" to describe a situation in which persons have complete uncertainty about their actual or true identities.

16. In plain words, the maximin criterion directs us to play it as safe as possible by choosing the alternative whose worst outcome leaves us better off than the worst outcome of all other alternatives. The aim of this strategy is to "maximize the minimum" regret or loss to well-being. To follow this strategy, Rawls says you should choose as if your enemy were to assign your social position in whatever kind of society you end up in. See Samuel Freeman, 
Harsanyi claimed that each person in the original position would maximize the sum of his or her expected utility. ${ }^{17}$

But how does one maximize expected utility under the conditions of absolute and total uncertainty that occur in the original position? Harsanyi developed a simple Bayesian or "equiprobability [model]" of decisionmaking in the original position. ${ }^{18}$ In brief, when there is no reason to assign a greater likelihood to one alternative over another, then an equal probability should be assigned to each potential outcome. ${ }^{19}$ After all, "if you have no more premonition of the likelihood of one option rather than another, they are for all you know equally likely to occur." ${ }^{20}$ By way of example, let's say that you are in the original position, so you do not know whether you will be assigned the role of shipper or grain miller, or more generally, of promisor or promisee. Your decision problem boils down to the question of what liability rule should you choose in this ex ante situation: (a) no liability, (b) the Hadley rule, or (c) total liability? To make this decision problem tractable, I will assume that potential promisors and potential promisees are Bayesian, ${ }^{21}$ and I will also make the following additional simplifying assumptions:

- TOTAL LIABILITY: You will be awarded $\$ 100,000$ for your losses in the event of breach if you are the miller (promisee), and you will have to pay out $\$ 100,000$ in the event of breach if you are the shipper (promisor);

- HADLEY RULE: You will receive $x$ for your losses in the event of breach if you are the promisee, and you will have to pay out $x$ in the event of breach if you are the promisor, where $x$ is small, that is where $0<x<\$ 100,000 / 2$;

- NO LIABILITY: You will be awarded $\$ 0$ for your losses in the event of breach if you are the promisee, and you will have to pay out $\$ 0$ in the event of breach if you are the promisor.

Now, if you knew ahead of time that you would assume the role of promisor once the veil of ignorance is lifted, you would prefer a rule of no liability; likewise, if you knew you would assume the role of promisee, you would prefer a rule of total liability. The problem, however, is that in the original position you cannot know what role

Original Position, STANFORD ENCYCLOPEDIA OF PHILOSOPHY (Winter 2016 \& Edward N. Zalta eds., 2016), https://plato.stanford.edu/archives/win2016/entries/original-position/.

17. See Harsanyi, supra note 15 , at 435 .

18. See id.; see also John C. Harsanyi, Can the Maximin Principle Serve as a Basis for Morality?: A Critique of John Rawls's Theory, 69 AM. POL. SCI. REV. 594, 598-99 (1975).

19. See generally ROBERT SCHLAIFER, PROBABILITY AND STATISTICS FOR BUSINESS DECISIONS (1959).

20. Freeman, supra note 16 .

21. See generally John C. Harsanyi, Cardinal Welfare, Individualistic Ethics, and Interpersonal Comparisons of Utility, 63 J. POL. ECON. 309 (1955). 
you will be assigned. So, which of the three liability rules should you choose? One way of solving this decision problem is to compare the worst-case and best-case scenarios under the different rules. For example, consider the two extremes: if you were a promisee, the best and worst possible outcomes are $+\$ 100,000$ (full recovery under the total liability rule) and $\$ 0$ (no recovery under the no liability rule), depending on which liability rule were selected in the original position. Likewise, if you were a promisor, the best and worst possible outcomes are $\$ 0$ (no liability) and $-\$ 100,000$ (total liability), depending on which liability rule were chosen in the original position.

Because there is an equal probability you will be assigned either the role of promisor or promisee in the original position (that is, pp'ee $=0.5$ and pp'or $=0.5$ ), the expected value of the best outcome for you in the role of promisor is $+\$ 50,000$ and the expected value of the worst outcome for you in the role of promisee is $-\$ 50,000$. Given this setup, we can now reframe our legal liability decision problem in Bayesian decision theory terms as follows: What if you had to choose between (i) a lottery ticket that had a 0.5 probability of rewarding you $\$ 50,000$ and a 0.5 probability of penalizing you $\$ 50,000$, and (ii) paying a definite amount of cash $x$. That is, how much would you be willing to pay to avoid this lottery ticket scenario? Even though the expected value of the lottery ticket described above (that is, a lottery ticket with an even probability of high losses and high gains) is 0 , my claim is that most people would be willing to pay some small sum to avoid being awarded such a lottery ticket. If my claim is correct, the reasonable foreseeability rule in Hadley makes the most sense ex ante. 


\section{Jacob \& Youngs, Inc. v. Kent}

\section{JEFFREY L. HARRISON*}

You can't always get what you want

But if you try sometime

You'll find

You get what you need.

-M. Jagger \& K. Richards ${ }^{1}$

Other cases present a genuine opportunity for choice-not a choice between two decisions, one of which may be said to be almost certainly right and the other almost certainly wrong, but a choice so nicely balanced that when once it is announced, a new right and a new wrong will emerge in the announcement.

-Benjamin N. Cardozo ${ }^{2}$

Generations of law students have studied Judge Cardozo's opinion in Jacob \& Youngs, Inc. v. Kent. ${ }^{3}$ The facts are simple. Kent contracted to have Jacob \& Youngs, Inc. build a dwelling. The contract specified that Reading pipe be used throughout. ${ }^{4}$ It was discovered that at least some of the pipe was not manufactured by Reading. ${ }^{5}$ Upon learning this, Kent refused to pay the balance due on the contract, reasoning that his obligation to perform was dependent on full performance by Jacob \& Youngs. ${ }^{6}$ Jacob \& Youngs attempted to present evidence that the actual pipe used was identical to Reading except for the name stamped into the metal every few feet, but the evidence was excluded and the trial court found for Kent. ${ }^{7}$

The appellate division reversed and, by a 4-3 decision, was affirmed by the court of appeals with Judge Cardozo writing the majority opinion. ${ }^{8}$ Judge Cardozo applied the doctrine of substantial performance. ${ }^{9}$ In effect, Kent could not suspend his performance once Jacob \& Youngs had substantially performed. Kent, though, was entitled to damages as measured by the difference in value of the dwelling if it had been completed as promised and its value as found as opposed to being measured by the cost of repair. ${ }^{10}$ Both the reasoning

* Huber C. Hurst Eminent Scholar Chair, College of Law, University of Florida.

1. The Rolling Stones, You Can’t Always Get What You Want (Decca 1969).

2. Benjamin N. Cardozo, The Growth of The LaW 58 (Yale Univ. Press 1924).

3. 129 N.E. 889 (N.Y. 1921).

4. Id. at 890 .

5. Id.

6. Id.

7. Id.

8. Jacob and Youngs, Inc. v. Kent, 129 N.E. 889 (N.Y. 1921).

9. Id. at 892 .

10. The alternative measure of damages - cost of repair-would have been tantamount to finding against Jacob and Youngs. 
and language of Judge Cardozo contribute to the case being a classic. Together they assist in his effort to avoid the "demon of formalism"11 and convince the reader that there is but one "right" answer.

\section{The Language}

The description of the facts of Jacob \& Youngs recited above is an accurate one. That does not mean, however, that it is the same story relayed by Judge Cardozo. Instead his version of the facts creates a context that feeds into his reasoning to make the outcome of the case seem inevitable. His version goes much more like this: A wealthy man contracted to have a million-dollar summer house built. ${ }^{12}$ He hired a builder and specified a type of pipe that was stamped with the name of its manufacturer every few feet. For the most part, the brand would not be visible. When he received the pipe, though it was the same quality of pipe, it had different branding than he contracted for, but there was no sign the builder had attempted to overcharge or substitute a lower priced pipe. The owner had no complaints about the pipe, and it seemed to function perfectly. Nearly a year after moving into his mansion, he discovered that the pipe was another brand and seized upon the opportunity to not make the remaining payment of $\$ 40,000 .^{13}$ The pipe was already part of the house, so Kent would be enriched at Jacob \& Young's expense unless required to pay the balance.

Of course, Judge Cardozo did not explicitly state it this way, but he, perhaps by design, introduced the opinion by providing a context, noting the wealth of Kent, noting the fact that there was a long delay before there were any complaints, noting that the amount remaining due was a pittance compared to the total price, and noting that the lower court decision resulted in a forfeiture by Jacob \& Youngs. Before any legal reasoning is presented the reader is left with the impression that the case involves opportunistic advantage-taking by the well-to-do. ${ }^{14}$

\section{The Reasoning}

Having told a story in which there could be only one fair answer, the challenge was then to string together a containable theory for

11. Benjamin N. Cardozo, The Nature of the Judicial Process 66 (Yale Univ. Press 1921).

12. Actually, the summer home cost $\$ 77,000$, but the reader of the opinion in 1921 would respond to that as a reader today would respond to nearly a million-dollar summer home. Allowing for inflation, a dollar in 1921 was the same as nearly $\$ 12.50$ in 2017 .

13. The actual amount withheld in 1921 dollars was $\$ 3,483$. Jacob and Youngs, Inc., 129 N.E. at 889. CPI Inflation CAlCUlator, BUREAU OF LABOR STATISTICS, https://www.bls.gov/data/inflation_calculator.htm [https://perma.cc/92KH-R6UX].

14. The same pattern is found in Wood v. Lucy, Lady Duff-Gorden. See Jeffrey L. Harrison, Teaching Contracts from a Socioeconomic Perspective, 44 ST. LoUIS U. L.J. 1233, 1239-40 (2000). 
why Jacob \& Youngs should recover even though they neglected to do what they promised to do. ${ }^{15}$ In other words, how to overcome the default position that one party's duty to perform was contingent on the performance of the other party to the contract. ${ }^{16}$ For this challenge, Judge Cardozo relied on a well-established doctrine of substantial performance. ${ }^{17}$ According to Judge Cardozo, the choice was between "symmetry and logic in the development of legal rules" and "practical adaptation to the attainment of a just result." ${ }^{18}$ In applying the doctrine, according to Judge Cardozo, "[w]e must weigh the purpose to be served, the desire to be gratified, the excuse for deviation . . . ${ }^{19}$ the cruelty of enforced adherence." ${ }^{\prime 20}$ In short, substance and balance were to be favored over a formulaic approach. ${ }^{21}$

Having decided that the doctrine of substantial performance should apply, Judge Cardozo was only halfway there. Kent was entitled to damages. Although Kent could not, in effect, avoid the contract, two very different measures of damages were available. One was the diminution in the value of the structure; the other was the cost to have the nonconforming pipe removed and replaced with Reading pipe. The measure of damages he applied was critical; awarding the cost of repair even in the context of substantial performance would have been a victory for Kent. Judge Cardozo conceded that the normal measure of damages was the cost of repair, "unless the cost of completion is grossly and unfairly out of proportion to the good to be attained." ${ }_{22}$ Here, Judge Cardozo likened the case to one in which granite from Vermont was required in the construction of a house which was actually built with granite of the same quality quarried in New Hampshire. In this example as in the case at hand, "the omission may not affect the value of the building for use or oth-

15. It is important to note that although Kent's obligation to perform would not be extinguished, a damages remedy was still available.

16. The dissent quoted at length from a case that indicated that the obligation to perform by one party was contingent on performance of the other party. Jacob \& Youngs, Inc., 129 N.E. at 893 (McLaughlin, J., dissenting) (quoting Smith v. Brady, 17 N.Y. 173, 186 (1858)).

17. The doctrine had been around since the late 1700's. See 2 E. ALLAN FARNSWORTH, FARNSWORTH ON CONTRACTS 488 (3d ed. 2004). Moreover, there was ample New York authority for the holding. See Spence v. Ham, 57 N.E. 412 (N.Y. 1900).

18. Jacob \& Youngs, Inc., 129 N.E. at 891.

19. According to Judge Cardozo, "[t]he transgressor whose default is unintentional and trivial may hope for mercy." Id.

20. Id.

21. Although the dissent quoted from a case that suggested a form-over-substance approach, most of the disagreement was based on the degree of fault by Jacob \& Youngs, Inc. Id. at 893 (McLaughlin, J., dissenting). The dissent argued that the application of the doctrine of substantial performance "depends in no small degree on the good faith of the contractor." Id. at 892.

22. Id. at 891 (majority opinion). 
erwise, except so slightly as to be hardly appreciable." ${ }^{23}$ The key to this second step was to once again place substance over form. The standard rule would have been to permit the cost of repair. Judge Cardozo, however, looked at the use to be made of the house and the financial impact on the two parties if the cost of repair was awarded. ${ }^{24}$ That would have been a windfall for Kent and unjust forfeiture for Jacob \& Youngs.

In the end, Kent did not get what he wanted; he got what he rightfully expected.

23. Id. (quoting Handy v. Bliss, 90 N.E. 864 (Mass. 1910) (emphasis added)).

24. Id. 


\section{Contracts' Enforcement and the Social Contract}

\section{HILA KEREN*}

Under the Social Contract Theory, individuals exchange some of their freedoms in return for the ability to live peacefully together, relieved as much as possible from harms caused by the aggression of other self-interested people. The sovereign, in turn, is entrusted with powers to organize society accordingly and to take care of its continuous existence. ${ }^{1}$ This explains why organized societies dedicate significant public resources to creating and maintaining many social institutions, including costly legal systems that, among other things, enforce private contracts. Such enforcement services support individual efforts to peacefully achieve joint goals by utilizing contracts and discourage people from resorting to acts of violent selfhelp if and when a breach occurs. On this view, when a given legal system enforces contracts it "performs" the social contract and, by this very act of performance, it simultaneously fosters the social contract's continuous existence as more people learn to rely on public solutions to private problems. Accordingly, when a consumer fails to pay his phone bill, a seller neglects to deliver a good to a buyer, or a partner breaches her duty of loyalty to the partnership (to give just a few examples), the legal system has a duty to support such contracts by enforcing them.

But what should a legal system do about "bad" contractscontracts produced by exploitation of known vulnerabilities or that include predatory terms? Should the legal system continue to award enforcement services or should it refuse the task? Notably, the dilemma arises directly from the social contract itself. While, in general, state enforcement indeed accords with the logic of the social contract, this may not be the case when the contracts themselves involve an excessive pursuit of self-interest and harm to others. In these cases, the celebrated "freedom of contract" that is guaranteed to private actors may have been overused to the point of risking the core idea of the social contract: keeping human communities together. The question then becomes-how should the law respond if it is to follow its role under the social contract?

The famous decision in Williams v. Walker-Thomas Company ${ }^{2}$ emulates this important dilemma. It does so not in the abstract, but in the very concrete setting of a distressed neighborhood in urban

* Professor of Law, Southwestern Law School.

1. See, e.g., Thomas R. POPE, Social Contract Theory IN American JURISPRUDENCE 3 (2013).

2. See Williams v. Walker-Thomas Furniture Co., 350 F.2d 445 (D.C. Cir. 1965). 
Washington D.C., ${ }^{3}$ and in a situation where a big retailer preyed upon the evident destitution of its clients. ${ }^{4}$ In general, the presiding judges in Williams could choose between three possible responses to a party's request for enforcement services. First, a court could order enforcement regardless of the predatory nature of the contract and without perceiving any difficulty with doing so. Second, it could acknowledge the predatory nature of the contract but nevertheless award enforcement, albeit reluctantly, due to a stronger commitment to rendering enforcement services. Or third, it could refuse enforcement because of the predatory nature of the contract.

Judge Danaher, who wrote the dissent for the federal D.C. Circuit Court of Appeals, took the first route. Referring to Ms. Williams, a poor, single-mother of seven, as "a relief client," Judge Danaher explained that she deserved no special empathy just because she stood to lose everything she had bought from Walker-Thomas over 4 years. ${ }^{5}$ Rather, reasoned the dissent, Ms. Williams "[knew] precisely where she stood." 6 Similarly, Judge Danaher clarified that the big corporation that manipulated Ms. Williams into signing rapacious terms deserves no condemnation as it took a "long chance" on selling to risky clients and thus designed terms that would "commensurate with the risk." The District of Columbia Court of Appeals chose the second route, clearly condemning the abuse of contracts, ${ }^{9}$ stating that it is the role of the state "to protect the public from such exploitive contracts." ${ }^{10}$ However, this appellate court saw itself as too powerless to express its disapproval of Walker-Thomas's actions and its empathy towards Ms. Williams by a refusal to enforce the predatory contract. Instead, the court insisted that such rejection of the contract could only come from the legislature.

With respect to legislative deference, Judge Wright, who wrote the majority opinion for the federal D.C. Circuit Court of Appeals, offered a much more empowered approach. To him, courts are not only authorized under the common law doctrine of unconscionability to refuse enforcement of predatory contracts without awaiting a legislative move, but are also under a duty to exercise their power to that

3. Anne Fleming, The Rise and Fall of Unconscionability as the "Law of the Poor," 102 GEO. L.J. 1383, 1391 (2014) (describing how Williams's "neighbors were almost all African-American and over a quarter also lived in poverty").

4. Id. at 1407 ("Walker-Thomas Furniture's methods were common among retailers to the poor.").

5. Williams, 350 F.2d at 450 (Danaher, J., dissenting).

6. Id.

7. Id.

8. Id.

9. Id. at 448 ("We cannot condemn too strongly appellee's conduct.").

10. Id. 
effect. ${ }^{11}$ In Judge Wright's words: "the court should consider whether the terms of the contract are so unfair that enforcement should be withheld." ${ }^{2}$ Consequently, the majority rejected the first two possible judicial responses and instead set up the modern unconscionability principle $^{13}$ that not only permits courts to withhold enforceability but also requires them to do so when "gross inequality of bargaining power"14 was used to produce contractual terms that are "so extreme as to appear unconscionable according to the mores ... . of the time and place." 15

Even though the case itself ended in a remand, it remains immensely important to our understanding of the role that law could and should play in responding to predatory contracts. ${ }^{16}$ What is at stake here, I argue, is the ability of law to impact the moral judgments of private actors. Nonlegal research demonstrates that people are inclined to do what they think is morally appropriate and to refrain from doing what they think is immoral..$^{17}$ Furthermore, people's "thinking" about morality is highly influenced by what they are led to feel by the many social cues that shape human emotions. ${ }^{18}$ Lawwith its mighty expressive power-is one of the most influential social cues that impact moral emotions and moral decisionmaking processes. ${ }^{19}$ For that reason, when the dissenting opinion blames the vic-

11. Hobson v. Hansen, 269 F. Supp. 401, 517 (D.D.C. 1967) (Judge Wright explained that when no legislative solution exists, "the judiciary must bear a hand and accept its responsibility to assist in the solution") (emphasis added).

12. Williams, 350 F.2d at 450 (emphasis added).

13. I use the term "principle" rather than "doctrine" to adopt Professor Melvin Eisenberg's important argument that the unconscionability idea is broader than what arises from blackletter law and is a fundamental principle of modern contract law. See MELVIN A. EISENBERG, BASIC PRINCIPLES OF CONTRACT LAW 1 (forthcoming 2019); see also Aditi Bagchi, Distributive Injustice and Private Law, 60 HASTINGS L.J. 105, 136 (2008) ("While unconscionability is a narrow doctrine in the common law, its underlying principles are of wider significance ....").

14. Williams, $350 \mathrm{~F} .2 \mathrm{~d}$ at 449 .

15. Id. at 450 (citing 1 CORBIN ON CONTRACTS $\S 128$ (1963)).

16. Generally, Williams v. Walker-Thomas and the modern unconscionability principle that was also codified under section 2-302 of the Uniform Commercial Code induced a heated scholarly debate. For critical examples see, Arthur Allen Leff, Unconscionability and the Code-The Emperor's New Clause, 115 U. PA. L. REV. 485 (1967) and Richard A. Epstein, Unconscionability: A Critical Reappraisal, 18 J.L. \& ECON. 293, 307, 315 (1975). For supportive works see, ROBIN L. WEST, The Anti-Empathic Turn, in PASSIONS AND EMotions 243, 245 (James E. Fleming ed., 2013); Duncan Kennedy, Distributive and Paternalist Motives in Contract and Tort Law, with Special Reference to Compulsory Terms and Unequal Bargaining Power, 41 MD. L. REV. 563, 634 (1982); Seana Valentine Shiffrin, Paternalism, Unconscionability Doctrine, and Accommodation, 29 PHIL. \& PUB. AFF. 205 (2000).

17. See, e.g., Paul Rozin, Freedom, Choice and Public Well-Being: Some Psychological Perspectives, 51 SOC. SCI. \& MOD. SOC'Y 237, 243 (2014).

18. See Jesse J. PRinz, The Emotional Construction of Morals 13 (2007).

19. See, e.g., Robert Cooter, Expressive Law and Economics, 27 J. LEGAL STUD. 585, 607-08 (1998); Richard H. McAdams, A Focal Point Theory of Expressive Law, 86 VA. L. 
tim (Ms. Williams) and rationalizes the behavior of the predator (Walker-Thomas) it stands to interrupt the operation of essential mechanisms of empathy and guilt, which throughout evolution operated to keep humans together. ${ }^{20}$

The brilliance of Judge Wright's decision comes from doing the opposite. He first frames the issue — contra the dissent ${ }^{21}$ —as a question of "mores," thereby creating an environment conducive to moral responses. ${ }^{22} \mathrm{He}$ then clarifies the moral norms, insisting that certain business behaviors, such as the use of a "rather obscure provision" 23 accompanied by "deceptive sales practices," can be inappropriate. ${ }^{24}$ This is an important step because when courts define some contractual practices as transgressions they enable future parties to anticipate that adopting such methods may induce unpleasant feelings of guilt and thus better to be avoided..$^{25}$ The decision further portrays Ms. Williams with empathy, a portrayal which is lacking from the dissent's opinion, and highlights her care for her children and the fact that she had responsibly managed to pay her debts for yearsboth against the odds rendered by her $\$ 218$ monthly income. Such induced empathy is crucial for the ability of everyone exposed to the decision $^{26}$ to grasp the magnitude of the harm caused by predatory contracts and to anticipate guilt for causing such harm. ${ }^{27}$ Overall, the Williams decision sends a clear legal message that helps all of uswithin and outside the law-feel the difference between right and wrong and avoid the latter. ${ }^{28}$ One can only hope that the more courts highlight the wrongfulness of predatory contracts, the more market actors will avoid imposing them and instead learn to adhere to fairness norms. But even if such hope cannot fully materialize, there is much comfort in knowing, following this decision, that our legal system is not helpless. Instead, it is ready to perform its most important

REV. 1649, 1729 (2000); Cass R. Sunstein, On the Expressive Function of Law, 144 U. PA. L. REV. 2021, 2022 (1996).

20. See generally Hila Keren, Guilt-Free Markets? Unconscionability, Conscience, and Emotions, 2016 BYU. L. REV. 427 (2016).

21. Judge Danaher, by contrast, framed the issue as interference in the "great latitude" of private actors "in making their own contracts." See Williams v. Walker-Thomas Furniture Co., 350 F.2d 445, 450 (D.C. Cir. 1965) (Danaher, J., dissenting).

22. Keren, supra note 20, 485-86, 494 (discussing how courts can create an environment that invites moral responses).

23. Williams, $350 \mathrm{~F} .2 \mathrm{~d}$ at 447.

24. Id. at 449 .

25. Keren, supra note 20, 486-89, 494.

26. Immediate readers, but also people who learn about it from other sources such as their legal counsel or the media.

27. Keren, supra note 20, 489-91, 494.

28. At minimum, the decision "drew attention to abuses in the low-income marketplace and helped bring about the passage of retail installment sales [legislation]." See Fleming, supra note 3 , at 1391. 
duty under the social contract theory: help our moral emotions function and keep us together despite the risks to our joint existence presented by unleashed greed. 
Everywhere a Cluck-Cluck: Frigaliment Importing Co. v. B.N.S. Int'l Sales Corp."

\section{Michael P. MALLOY ${ }^{\dagger}$}

\section{Introduction}

Whenever I teach a contracts course and reach the subject of contract interpretation, I am tempted to place Frigaliment Importing Co. v. B.N.S. International Sales Corp. ${ }^{1}$ on the desk, wind it up like one of those little plastic chicks you get during the holidays, and just let it run. The case would whirr and cluck-cluck through a range of issues, imparting knowledge and understanding to my students in a methodical, clear, and effective manner. Of how many cases (or class discussions) can one honestly make such a claim? The opinion by Circuit Judge Henry J. Friendly ${ }^{2}$ is well written, incredibly thorough, witty, and probably one of the most helpful guides to the use of extrinsic sources imaginable. These qualities earn the case my vote as "best contracts case."

\section{Case Summary}

For those only casually acquainted with edible birds, Frigaliment begins its analysis of the dispute between the parties with a startling question:

The issue is, what is chicken? Plaintiff says 'chicken'[3] means a young chicken, suitable for broiling and frying. Defendant says 'chicken' means any bird of that genus that meets contract specifications on weight and quality, including what it calls 'stewing

* Copyright (C) 2017 Michael P. Malloy.

$\dagger$ Distinguished Professor \& Scholar, University of the Pacific McGeorge School of Law. J.D., University of Pennsylvania (1976); Ph.D., Georgetown University (1983).

1. 190 F. Supp. 116 (S.D.N.Y. 1960).

2. Shortly before this case, Judge Friendly left private practice and was appointed to the Second Circuit. He volunteered, given his limited past trial court experience, to sit as a district court judge in the Frigaliment case. DAVID M. DORSEN, HENRY FRIENDLY: GREATEST JUDGE OF HIS ERA 60, 81, 315 (2012). Is it possible that great judges make for great cases?

3. Here, and consistently throughout the opinion, Judge Friendly uses single quotation marks. I do not know why, but I would like to think that he realized that the opinion was worthy of quotation-in double quotation marks-with his own internal quotation marks already preadjusted to singles. Commentators almost uniformly miss this usage and will use double quotation marks when repeating this passage in an indented quotation. See, e.g., Aaron D. Goldstein, The Public Meaning Rule: Reconciling Meaning, Intent, and Contract Interpretation, 53 SANTA ClaRA L. REV. 73, 110 (2013) (misplacing Friendly's single quotation marks with doubles in direct, indented quotation). 
chicken' and plaintiff pejoratively terms 'fowl.' Dictionaries give both meanings, as well as some others not relevant here. ${ }^{4}$

In Frigaliment, the purchaser of fresh, frozen "chicken" brought an action against the seller for breach of warranty. The purchaser said that it had wanted chickens suitable for broiling and frying, and that was what the contract required. The district court reviewed the text of the contract and applied a variety of extrinsic sources to determine what the term "chicken" meant. The court held that the purchaser had failed to sustain its burden of proving that the word "chicken," as used in the contract, referred only to broilers and fryers and did not include stewing chickens.

In reaching this result, Frigaliment considers, in succession, a variety of interpretive sources. First, of course, there is the language of the contract itself. "Since the word 'chicken' standing alone is ambiguous, I turn first to see whether the contract itself offers any aid to its interpretation." ${ }^{5}$ Second, Judge Friendly considers trade usage and other sources of extrinsic evidence. Is it possible "that there was a definite trade usage that 'chicken' meant 'young chicken' "? ${ }^{6} \mathrm{We}$ would need to know more about common practices in the trade. ${ }^{7}$ Third, if the transaction occurred within an identifiable regulatory context, it is possible "that the contract incorporated [the Department of Agriculture's] regulations by reference," ${ }^{\circ}$ which might help explain the meaning and effect of the term. Fourth, the structure and pricing of the relevant market might suggest what the term "chicken" would mean in the context of their contract." Finally, the conduct of the parties during the operation of the contract-what the UCC would call the course of performance ${ }^{10}$ - might reveal, by inference from their behavior, what the parties thought the term meant in the contract that they were carrying out. ${ }^{11}$ Reviewing the results of each of these sources of contract interpretation, Judge Friendly concludes that the plaintiff had failed to carry its burden to demonstrate "that 'chicken' was used in the narrower rather than in the broader sense." 12

4. Frigaliment, 190 F. Supp. at 117.

5. Id. at 118 .

6. Id. at 119 .

7. Cf. $i d$. at 119-29 (discussing evidence from which relevant trade usage might be established terms).

8. Id. at 120 .

9. Id.

10. See U.C.C. § 1-303(a) (AM. LAW INST. \& UNIF. LAW COMM"N 2001) (defining "course of performance" to mean "a sequence of conduct between the parties to a particular transaction" under specified circumstances involving "repeated occasions for performance").

11. Frigaliment, 190 F. Supp. at 120-121.

12. Id. at 121 . 


\section{Conclusion}

The heart of the decision is the identification and analysis of pertinent sources of extrinsic evidence on the meaning of the contract term in contention. One must remember that this case arose before enactment of the UCC. Currently, what sources might we look to ${ }^{13}$ The UCC gives us a compact set of interpretive rules, none of which are inconsistent with Frigaliment. ${ }^{14}$ However, post-UCC cases continue to recognize that extrinsic sources that aid in interpretation are broader than those identified in section 1-303 of the UCC, ${ }^{15}$ and they continue to cite Frigaliment and similar cases as pertinent authority. Certainly in a commercial case like Frigaliment, part of the defining context would be the market structure for products with particular commercial and consumer applications, and that is still likely to be so in contemporary cases. ${ }^{16}$ Frigaliment remains a case cited with authority $^{17}$ and affection ${ }^{18}$ today.

13. See, e.g., RESTATEMENT (SECOND) OF CONTRACTS $§ 202$ (AM. LAW INST. 1981) (providing interpretive rules).

14. See U.C.C. § 1-303 (AM. LAW INST. \& UNIF. LAW. ComM’N 2017) (defining course of performance, course of dealing, and usage of trade, thus setting their parameters); id. §2202 (allowing for the use of these sources to "explain \ or supplement \" written contract terms).

15. Courts and commentators have sometimes been criticized for departing from UCC terminology in this regard. See, e.g., David G. Epstein, Adam L. Tate, \& William Yaris, Fifty: Shades of Grey-Uncertainty About Extrinsic Evidence and Parol Evidence After All These UCC Years, 45 ARIZ. ST. L.J. 925, 926-27 (2013) ("Too often, the reported opinions in post-UCC cases that involve a dispute over interpreting a term in or adding terms to a written contract for the sale of goods do not use the language of the UCC. Instead, attorneys and judges use (and misuse) the terms 'extrinsic evidence,' 'parol evidence,' and the 'parol evidence rule,' rather than the language of Article 2."). However, I fail to see how such flexibility in terminology has led to misapplication of the applicable legal principles or that - for example-Frigaliment would have reached a materially different result if it had been a UCC case. In any event, one cannot give much weight to anyone who alludes to $\mathrm{E}$. L. James's 2011 erotic romance novel in the title of a scholarly article, or, for that matter, in a footnote in an otherwise refreshing analysis of Frigaliment.

16. See, e.g., ProCD, Inc. v. Zeidenberg, 86 F.3d 1447, 1450 (7th Cir. 1996) (applying UCC provisions and looking to market structure and pricing in analyzing the contract at issue). But cf. Malloy on ProCD p. 999 (arguing that ProCD is the worst contracts case, on other grounds).

17. See, e.g., Rossi v. N.Y. City Dept. of Parks and Recreation, 8 N.Y.S.3d 25, 33 (N.Y. App. Div. 2015) (citing Frigaliment, considering the definition of "goods").

18. See, e.g., Royal Am. Mgmt, Inc. v. WCA Waste Corp., 154 F. Supp. 3d 1278, 1280 (N.D. Fla. 2016) (citing Frigaliment, considering "a more difficult question: did the chicken or the egg come first?"). 
ProCD, Inc. v. Zeidenberg: How an Opinion that Some Believe Deserves an " $F$ " as a Law-School Exam Answer was one of the Greatest Contracts Opinions Ever Written

\section{DANIEL P. O'GORMAN*}

Few contracts cases in recent decades have evoked as much controversy as ProCD, Inc. v. Zeidenberg, ${ }^{1}$ in which Judge Frank H. Easterbrook of the United States Court of Appeals for the Seventh Circuit adopted the rolling-contract formation theory. ${ }^{2}$ Under this theory, if an offeree has reason to believe that an offer to sell goods includes hidden terms that will not be disclosed until some point after payment (such as the terms being in a box with the goods), acceptance of the offer does not occur until after the buyer has the opportunity to review those terms, provided that the buyer is given the option to return the goods. ${ }^{3}$

This theory, while sounding favorable to consumers, ${ }^{4}$ was in fact a way to help sellers bind consumers to a seller's hidden terms. Without the theory, the hidden terms would not be part of the deal because they were not disclosed prior to acceptance and would thus be a proposal by the seller to modify the contract that would need separate assent from the buyer. By rolling back the time of acceptance to after the buyer has access to the additional terms, the buyer is considered to have manifested assent to them if she does not reject the offer by returning the goods.

The opinion tackled what has since become known as the "Gateway problem," named after Judge Easterbrook's subsequent opinion applying the theory-Hill v. Gateway 2000 , Inc. ${ }^{6}$ The Gateway problem arises from the fact that it is often difficult for sellers to disclose, at the time the buyer pays for the goods, all of the desired terms of

* Associate Professor of Law, Barry University, Dwayne O. Andreas School of Law.

1. 86 F.3d 1447 (7th Cir. 1996); see also Oren Bar-Gill et al., Searching for the Common Law: The Quantitative Approach of the Restatement of Consumer Contracts, 84 U. CHI. L. REV. 7, 18 (2017) ("Few contract cases have generated as much controversy ....”).

2. See John E. Murray, Jr., The Dubious Status of the Rolling Contract Formation Theory, 50 DUQ. L. REV. 35, 35 (2012) (referring to the theory as the "rolling contract formation theory").

3. ProCD, Inc., 86 F.3d at 1450-53; see also Andrew Vogeler, Note, Rolling Contract Formation and the U.C.C.'s Approach to Emerging Commercial Practices, 30 J.L. \& CoM. 243,248 (2012) (explaining when the theory applies).

4. See Murray, supra note 2, at 71-72 ("By providing the buyer with the ability to read and digest these terms at the buyer's leisure with the right of objection and the return of the purchase price, the rolling theory suggests a consumer protection purpose ....").

5. Jean Braucher, Delayed Disclosure in Consumer E-Commerce as an Unfair Trade Practice, 46 WAYNE L. REV. 1805, 1819 (2000).

6. 105 F.3d 1147 (7th Cir. 1997). 
the deal. ${ }^{7}$ Consider, for example, buying packaged software from a retail store or ordering a computer by telephone. The rollingcontract formation theory enables terms that were undisclosed at the time of purchase to become part of the deal. It also gives the buyer the ability to avoid the deal if the buyer, after having access to the terms, finds them objectionable. The theory provides a sensible solution to the problem.

The solution, however, which has been described as "a radical change in contract formation theory," "was met with hostility from most of the academy. ${ }^{9}$ Why such outrage? Much of the criticism focused on the belief that Judge Easterbrook's theory ignores and misapplies certain provisions of Article 2 of the Uniform Commercial Code (UCC) and twists formation doctrine to reach a result in the name of efficiency, thus putting law-and-economics adherence above blackletter contract doctrine. ${ }^{10}$ Professor Stewart Macaulay even wrote that Judge Easterbrook's Gateway opinion received an "F" as a law-school exam answer. ${ }^{11}$ Those who argued that Judge Easterbrook's rolling-contract formation theory was difficult to square with specific UCC provisions and traditional common law notions of contract formation made many good points. ${ }^{12}$ There were

7. Eric A. Posner, ProCD v. Zeidenberg and Cognitive Overload in Contractual Bargaining, 77 U. CHI. L. REV. 1181, 1181 (2010).

8. Murray, supra note 2, at 36 .

9. See Roger C. Bern, "Terms Later" Contracting: Bad Economics, Bad Morals, and a Bad Idea for a Uniform Law, Judge Easterbrook Notwithstanding, 12 J.L. \& POL'Y 641, $643 \&$ n.5 (2004) (noting that the opinion has been widely criticized and listing the articles that criticize it).

10. See, e.g., Murray, supra note 2; Bern, supra note 9, at 644-87; Braucher, supra note 5, at 1819-24; Robert A. Hillman, Rolling Contracts, 71 FoRDHAM L. REV. 743, 752-55 (2002).

11. Mark S. Scarberry, The Gateway Thread-AALS Contracts Listserv, 16 TouRo L. REV. 1147, 1148 (2000) (statement by Stewart Macaulay).

12. For example, Judge Easterbrook incorrectly stated that section 2-207 only applies if there are two forms. Hillman, supra note 10, at 753. He also ignored section 2-206(1)(b), which provides that "an order . . . to buy goods for prompt or current shipment shall be construed as inviting acceptance either by a prompt promise to ship or by the prompt or current shipment . . ." Murray, supra note 2, at 47-48; Hillman, supra note 10, at 753-54. Further, section 2-206(1) provides that a specific method of acceptance must be indicated unambiguously. Hillman, supra note 10 , at 754 . He also ignored the possibility that the transaction was a sale on approval under section 2-326. The Gateway Thread, supra note 11, at 1179 (statement of Mark S. Scarberry). Judge Easterbrook's subsequent application of the theory in Gateway also assumed that the seller of a computer over the telephone was the offeror (something necessary for the theory to apply), yet typically the buyer is the offeror in that situation. Murray, supra note 2, at 50. These arguments can, however, be countered: Section 2-207 does not apply if the acceptance matches the offer. Section 2-206(1)(b) would not apply if the buyer is not the offeror, or if the buyer had reason to know that acceptance would not occur upon a promise to ship or shipment; a required method of acceptance can be indicated unambiguously by the circumstances; "sale on approval" typically refers to a situation in which the buyer tests the goods; and if a caller has reason to know that there are hidden terms the caller has reason to know that the seller is not ac- 
also good arguments that his practical solution to the problem was not the best solution. ${ }^{13}$

So why then is an opinion that is susceptible to so many valid criticisms one of the greatest contracts opinions ever written? Because not only did Judge Easterbrook identify a legal problem and seek to solve it, he did so in an opinion that-despite its flaws-is a masterpiece of legal reasoning; an opinion in which he justified his solution both doctrinally and functionally.

Judge Easterbrook understood that any solution to the hiddenterms problem had to be worked out within the confines of Article 2 of the UCC. ${ }^{14}$ Accordingly, a portion of his opinion is devoted to explaining how the rolling-contract formation theory is in fact simply an application of UCC rules, including the provisions indicating that agreement can be shown in any manner and that the offeror can specify a specific method of acceptance. ${ }^{15}$ Although he has been criticized for ignoring and misapplying certain UCC rules, ${ }^{16}$ Judge Easterbrook surely understood that the UCC should not be construed in an overly formalistic fashion that would stifle the solution to new problems in contract law. ${ }^{17}$ After all, the UCC was designed, in part, to "modernize the law governing commercial transactions" and "to permit the continued expansion of commercial practices through custom, usage, and agreement of the parties." 18 It is curious that so many law professors who decry formalism took umbrage at Judge Easterbrook's lack of it.

Judge Easterbrook also explained why the rolling-contract formation theory was good policy, arguing that his solution reduced transaction costs in contract formation-a benefit to both parties. ${ }^{19}$ There was no hiding the ball here-Judge Easterbrook laid it all out, explaining, in his professorial style, why the theory was beneficial for contracting. As noted, there have been good arguments that the rolling-contract formation theory is not the best solution to the problem

cepting the caller's offer by promising to ship or shipping the goods, in which case the seller is the offeror.

13. See Murray, supra note 2, at 76-77.

14. See ProCD, Inc. v Zeidenberg, 86 F.3d 1447, 1452 (7th Cir. 1996).

15. Id. at $1452-53$.

16. See Murray, supra note 2 .

17. See, e.g., Richard A. Epstein, ProCD v. Zeidenberg: Do Doctrine and Function Mix?, in CONTRACT STORIES 94, 104 (Douglas Baird, ed. 2007) (“[Judge Easterbrook's] functional view of the law of contract is that it allows bargains by which both parties are able to improve their economic position. It therefore seems odd that any body of contract doctrine, either at common law or under the UCC, should adopt a version of the contract that does not appear to satisfy that condition of mutual gain.").

18. U.C.C. § 1-103(1)-(2) (AM. LAW INST. \& UNIF. LAW. COMM’N 2017).

19. ProCD, Inc., 86 F.3d at 1451-52. 
of hidden terms. ${ }^{20}$ But we should keep in mind that Judge Easterbrook is a judge, not a legislator; judges typically do not have the time, the input from experts, or the resources to always craft the perfect solution to a complicated legal problem in a single court opinion. If their proposed solution can be improved upon, the system provides for this through subsequent court opinions or statutory changes. And we should remember that a federal judge does not tell any state court what its rules of contract law are; he merely predicts what they are or would be. ${ }^{21}$ If Judge Easterbrook's new theory is flawed, it can be rejected or modified. Importantly, though, Judge Easterbrook's opinion started the conversation about solving a thorny problem. ${ }^{22}$

Perhaps ProCD would not be a good law-school exam answer. But good exam answers typically demonstrate an ability to properly apply existing law. In contrast, great court opinions do something different-they move the law forward to solve new legal problems, and in doing so they fully explain the policy reasons behind the proposed solution. Judge Easterbrook's ProCD opinion-flaws notwithstanding-did all of this and was thus one of the greatest contracts opinions ever written.

20. Murray, supra note 2, at 76-77.

21. See MindGames, Inc. v. W. Publ'g Co., Inc., 218 F.3d 652, 655-56 (7th Cir. 2000) ("[F]ederal court[s] must predict how the state's highest court would decide the case ....").

22. It is worth noting, however, that more than two decades later, Judge Easterbrook's theory has been adopted by many of the courts that have considered the issue. BarGill, supra note 1, at 18. But see Murray, supra note 2, at 36 ("Suggestions that subsequent cases have installed the rolling theory as the prevailing view are, at the least, premature.") (footnote omitted). 


\section{Of Milk, Markets, Populism and Promissory Estoppel: State Bank of Standish v. Curry}

\section{DEBORAH POST ${ }^{*}$}

As a law professor, I believe the best cases are those that provide sufficient detail so that students can understand (i) the lived experience or circumstances of the parties to the contract, (ii) the way in which the dispute represents or reflects broader social and political issues in our society, and (iii) a majority and dissent in which there is a clear exposition of the legal theories that led the judges to disagree about the proper resolution or outcome in the case. State Bank of Standish v. Curry does all three. ${ }^{1}$ That makes it one of the best cases not currently in the canon.

In a casebook, it is important to have cases that set out the law, cases that illustrate how the law has changed or evolved, and a representative sample of cases that demonstrate the ubiquity of contracts. It is also important to include cases from a wide variety of commercial and noncommercial settings. A case about the relationship between farmers and banks raises issues about the recurring credit crisis for farmers in the United States. ${ }^{2}$ Political and economic struggles, past and present, are implicated in contract disputes between farmers and banks. Given how important agriculture is in the United States-economically, politically, and culturally-cases like State Bank of Standish deserve more attention than they currently receive. ${ }^{3}$

Additionally, State Bank of Standish has what Clifford Geertz called "thick description." "The relationship between law and fact is

* Professor Emeritus, Touro College, Jacob D. Fuchsberg Law Center.

1. State Bank of Standish v. Curry, 500 N.W.2d 104 (Mich. 1993).

2. See David Shribman, Iowa's Story is America's, Boston GLoBE, Jan. 24, 2000, at A1, in KASTEly, Post, OTA \& ZALESNE, CONTRACTING LAW 521 (5th ed. 2015) (describing the fraught relationship between farmers and bankers from the time of the Cow Wars in Iowa in the 1930 s and the crisis in farming in the $1980 \mathrm{~s}$ and today).

3. Agriculture and farming production amounted to $\$ 136.7$ billion, or 1 percent, of the gross domestic product of the United States in 2015. Wide swathes of farmland can be found in virtually every state. Although the public has heard a great deal about "corporate farms," nonfamily farms accounted for only 11 percent of the agricultural production in 2015 . The "large scale" family farms compose 42 percent of total production on farms. Ag and Food Sectors and the Economy, U.S. DEP'T OF AGRIC., https://www.ers.usda.gov/data-products/agand-food-statistics-charting-the-essentials/ag-and-food-sectors-and-the-economy.aspx\#. WS7MLxIIluk.email [https://perma.cc/8F69-YCYP]. The cases in the canon that are commonly found in casebooks include the two farmers in Virginia who entered into a contract while they were both "high as Georgia pine," and the Southworth v. Oliver, 587 P.2d 994 (Or. 1978), which involves a dispute over land and grazing permits in Oregon.

4. Clifford Geertz, The InTERPretation of Cultures 6 (1973). Geertz explored the relationship between law and anthropology and the use of facts discussed in the Storrs Lectures he delivered in 1969. The lectures were published in CLIFFORD GEERTZ, LOCAL 
not incidental or ancillary to the project of teaching legal doctrine. Cases which provide more details about the parties and the transactions improve a student's understanding of the relevance and application of legal doctrines. "Thick description" in State Bank of Standish provides information about family farms, the dairy industry, the long-term relationships between farmers and the banks that finance their operations, and federal involvement or intervention in the "free market" for agricultural products. ${ }^{5}$

This was not a simple foreclosure that resulted in the debtor claiming that a promise had been made in order to extend or renew financing. ${ }^{6}$ In this case, the farmer had both an explicit statement that financing would be provided and an alternative course of action if the bank gave notice that it would not renew the loan. An offer from the federal government to buy his herd was on the table, and there was also a possibility that the Curry's could sell their registered herd in Canada. ${ }^{7}$ Interestingly, it is not the majority but the dissent that quoted the testimony of Robert Curry about the exchange he had with bank officers: "[A]re you with me or against me. I wanted to know, should I continue farming, or should I get out, and, basically the bottom line was, you've done a good job, you've made your payments, we're with you."

KNOWLEDGE, FURTHER ESSAYS IN INTERPRETIVE ANTHROPOLOGY 167-237 (1983). I would also cite John Noonan as a critic of "thin" opinions that dehumanize the litigants:

Apart from [f]amily [1]aw, no great attention is given to the impact of the rule upon the individual lives of the litigants. . . . To a very large degree, those interests are so many severed heads, detached from the persons who carried them. Such a way of study permits masks to be taken for persons.

JOHN NOONAN, PERSONS AND MASKS OF THE LAW 7 (1976).

5. The federal government attempted to stabilize milk prices in 1986 and offered a "dairy herd buy out." Standish, 500 N.W.2d at 105. The latest controversy over milk supply involves the U.S. government imposing tariffs on Canadian lumber imported to the United States in retaliation for Canadian tariffs on ultrafiltered U.S. milk exported to Canada from Wisconsin and Upstate New York for the production of cheese. See, e.g., Caitlin Dewey, President Trump's Sudden Preoccupation with Milk, Explained, CHICAGo TrIBUNE (April 25, 2017), http://www.chicagotribune.com/news/nationworld/ct-trump-canada-milksoftwood-tariff-20170425-story.html [https://perma.cc/S5XK-ATY9].

6. The majority painfully tries to distinguish this case from others where there had been only preliminary discussions of a loan, or general discussions of past renewals or reassurances regarding past performance because these would not "meet the promissory ideal." Standish, 500 N.W.2d at 107, n.3.

7. The federal government, concerned about overproduction-a problem that continues to plague farmers today-had offered to buy Curry's herd of dairy cattle and because his herd was registered, it could also have been sold in Canada. See also Kelsey Gee, America's Dairy Farmers Dump 43 Million Gallons of Excess Milk, WALL ST. J. (Oct. 12, 2016), https://www.wsj.com/articles/americas-dairy-farmers-dump-43-million-gallons-of-excessmilk-1476284353 (discussing the overproduction of milk).

8. Standish, 500 N.W.2d at 112. This might remind students of Embry v. McKittrick's "Go ahead, you're all right. Get your men out, and don't let that worry you." Embry v. Hagardine, McKittrick Dry Goods Co., 105 S.W. 777, 777 (1907). 
The majority opinion by Justice Patricia Boyle and the dissenting opinion by Judge Dorothy Comstock Riley do not disagree about the events that occurred as much as they disagree about the significance and the meaning that should be assigned to those facts. ${ }^{9}$ The doctrinal and ideological divide in the two opinions concerns the purpose and the reach of the doctrine of promissory estoppel, but also norms that should govern the conduct of those who do business with one another. ${ }^{10}$

The two sides square off in an ideological debate about the purpose and use of the doctrine of promissory estoppel. The majority acknowledges that there is an ongoing debate about the use of the doctrine,${ }^{11}$ but finds its justification in the need for trust in commercial relationships. ${ }^{12}$ It fills the gaps in the contractual relationship with evidence of a course of dealing between the parties. ${ }^{13}$ The dissent, on the other hand, defends the bank's action by pointing to facts that show the increase in debt over time and the less than fastidious record keeping of the Currys. ${ }^{14}$ Promissory estoppel is a doctrine that is explicit in requiring an examination of the facts to determine "what justice requires." ${ }^{5}$ Judge Riley believes this justice principle or doctrine has no place in "complex commercial transactions."16

A case like Standish offers an opportunity for a deeper exploration of an opposition set out in the case between the ideals of trust and

9. State Bank of Standish v. Curry, 500 N.W.2d 104 (Mich. 1993).

10. Or, as Corbin often referred to it, the "mores" that should govern the behavior of reasonable men and women. Corbin insisted that "a just and reasonable man will not insist on profiting on another's mistake." CORBIN ON CONTRACTS 609 (1960).

11. Standish, 500 N.W.2d at 108 .

12. The majority notes that "[p]romissory estoppel developed to protect the ability of individuals to trust promises in circumstances where trust is essential" but also notes that "[c]ourts are variably strict and flexible in determining whether a manifestation of intent may furnish a basis for promissory estoppel." Id. at 107-08.

13. The majority notes that "if there exists a method of determining the terms of the contract by examining the agreement itself or custom and usage" or if there has been a "previous course of dealing" that supplies "some objective method by which the missing terms could be supplied" the doctrine of promissory estoppel can be applied. Id. at 109-10.

14. The bank informed the Curry's that the "Tel Farm' statement" was a "record keeping system" that produced "income and expense records." There were omissions involving the "outstanding debt owed to the bank." Id. at 111-12 (Riley, J., dissenting).

15. Restatement (SECOND) OF Contracts $\$ 90$ (AM. LAW INST. 1981) (The promissor "should reasonably expect to induce action or forebearance on the part of the promissee" and the promise must "induce" either "action or forebearance" for the promise to then be "binding if injustice can be avoided only by enforcement of the promise." Id. $§ 90$ cmt. b ("[E]nforcement must be necessary to avoid injustice."). A discussion of the requirement of justice or the existence of an injustice takes students and faculty into a realm where there is no rule, as such, but an invitation to examine underlying values and moral sensibilities.

16. According to Judge Riley, promissory estoppel too liberally applied would "result in an unwitting and unintended undermining of the traditional rule requiring consideration for a contract. This is particularly true where the promise is the loan of money." Standish, 500 N.W.2d at 113 n.4. 
business necessity. The majority opinion can be read as relational ${ }^{17}$ or realist, ${ }^{18}$ but it also can be used to explore the persistence over time of an agrarian sensibility-a populist sentiment. ${ }^{19}$

The Agrarian and the Populist Movement ended 200 years ago, but the ideas and beliefs endure. ${ }^{20}$ Beliefs that become part of a national or regional identity have a way of reconstituting themselves in recurrent political struggles. And if the admiration of the "yeoman farmer" or the resentment towards banks or "big money" that existed in the nineteenth century persists, it may be found in the credence given to the testimony of a farmer and the rejection of the arguments of the bank that was about to take all the farmer owned, including his home.

17. Jay Fineman, Relational Contract Theory in Context, 94 Nw. U. L. REV. 737 (2000).

18. The use of gap fillers like course of dealing or custom and usage in a manner consistent with the Uniform Commercial Code Article 2 would be a "realist" approach. Karl Llewellyn, Realism about Realism, 44 HARV. L. REV. 1222 (1931); Brian Leiter, Legal Realisms, Old and New, 47 VAL. U. L. REV. 67 (2013).

19. My go to source on agrarian myths and populist sentiments is RICHARD HOFSTADTER, THE AGE OF REFORM, FROM BRYAN TO F.D.R (1955). Hofstader's history is not simply about the Populist party but about a "popular impulse that is endemic in American political culture." Id. at 4. It might also be interesting to discuss the considerable political power farmers have with respect to crop subsidies, government financing, or simply political sensitivity to the ideals of "values voters." A brief description of the advocacy for farmers can be found at About us, FARM AID https://www.farmaid.org/about-us/ [https://perma.cc/8RDX-3L5T].

20. For a summary description of the populist movements in the United States from the Farmers Revolt in the late 19th Century to the present day, see Steven M. Gillon, Why Populism in America is a Double-Edged Sword, HISTORY (Jan. 5, 2018), http://history.com/news/whypopulism-in-america-is-a-double-edged-sword [https://perma.cc/LL92-9XVJ]. There is a certain irony, we should all admit, in the way President Donald Trump, a New Yorker and real estate mogul, has embraced populism. His tweets on the subject of milk were particularly interesting. See, e.g., Brian Barth, Explainer: Trump's Milk War with Canada, MODERN FARMER (May 18, 2017), https://modernfarmer.com/2017/explainer-trumps-milk-war-canada/? [https:/perma.cc/ D974-9XE6]. 


\section{The Democratization of Contract Law: The Case of Mutual Promises}

\section{VAL RICKS*}

The common law has always enforced promises given in exchange, ${ }^{1}$ but in exchange for what? Very early on, standard responses were "property conveyed" owners could convey property, and the wealthy could wait to be bound until others performed. The law primarily served those with wealth. But five centuries ago, a common law court decided that a promise was enforceable when given for another promise. Anyone can make or exchange a promise. This decision severed contract law from acquired wealth. ${ }^{4}$ It based contract law on mutual trust. Because of this decision, any human being can trade enough to bind another. Contract could expand into all areas of human activity. Contract could become a human right. This was the best common law contracts case ever decided.

Unfortunately, we do not know which case it was, and the law took several decades to resolve the issue. Chief Justice John Fyneux of the King's Bench most likely brought the first mutual promise case in $1518,{ }^{5}$ but we do not know its outcome. ${ }^{6}$ Wagering cases (usually mutual promises) were brought in the $1530 \mathrm{~s}$, but again no decisions were recorded. ${ }^{7}$ These cases predated the development of the consideration doctrine (which occurred between 1539 and 1560). ${ }^{8}$

* Charles Weigel II Research Professor and Professor of Law, South Texas College of Law Houston.

1. See, e.g., A.W.B. Simpson, A History of the Common LaW of Contract: The RISE OF THE ACTION OF ASSUMPSIT 424-26 (1975); J. RASTELL, EXPOSITIONES TERMINORUM (1525), in J.H. BAKER \& S.F.C. MILSOM, SOURCES OF ENGLISH LEGAL History: PRIVATE LAW TO 1750, at 483 (1986); See also David J. Ibbetson, Consideration and the Theory of Contract in Sixteenth Century Common Law, in Towards A GENERAL LAW OF ConTRACT 68 (John Barton ed. 1990) (recounting the sixteenth-century history of assumpsit and noting that "[i]n substance this is identical to the quid pro quo of the action of debt, and . . . there was an organic connection [sic] between the two ideas.") (citation omitted).

2. See, e.g., RASTELL, supra note 1; Calthorpe's Case (1574) 73 Eng. Rep. 756, 759 (C.P.) (Dyer, J).

3. See Calthorpe's Case, 73 Eng. Rep. at 759.

4. Of course, it would have been possible prior to this for two people to encapsulate what we might (with considerable distortion) call mutual promises in two sealed conditional bonds. See SIMPSON, supra note 1, at 112-13. But that act, done well, required that both parties be able to read the documents or hire someone to do so. That was hardly a substitute for mutual, parol promises.

5. 2 THE REPORTS OF SIR JOHN SPELMAN 268 (J.H. Baker ed. 1978), in 94 THE PUBliCATIONS OF THE SELDEN SOCIETY (1977) (discussing Fyneux v. Clyfford (1518) KB 27/1026).

6. Id.

7. Id. at 286 n.5.

8. See J.H. Baker, Origins of the "Doctrine" of Consideration, 1535-1585, in ON THE LAWS AND CUSTOMS OF ENGLAND: ESSAYS IN HONOR OF SAMUEL E. THORNE 336-58 (Morris 
As the consideration doctrine was maturing, however, arguments about mutual promises appeared in two cases. In Lucy v. Walwyn, argued in 1561, ${ }^{9}$ Simon Walwyn, a friend of John Swyfte, promised Thomas Lucy to "do his utmost" to persuade Swyfte to sell to Lucy two parcels of real estate. ${ }^{10}$ Walwyn promised to do so in exchange for Lucy's promise of a gelding worth 100 shillings or cash in that amount, plus all expenses. ${ }^{11}$ Walwyn breached his promise by buying the properties for himself.

In another case, West $v$. Stowell, reported in $1577,{ }^{12}$ the parties bet on an archery match. John Stowell was shooting with Charles Howard. Thomas West, a bystander, bet Stowell £10 that Howard would win. Stowell took the bet but lost the match. ${ }^{13}$ Stowell refused to pay. ${ }^{14}$

The opinions in these cases record the arguments for and against mutual promises as consideration. In both cases, the defense lawyers argued that the plaintiff's promise was not enough to justify the lawsuit: (i) a promise is insufficient in reason and in law (there was no precedent), ${ }^{15}$ and (ii) the plaintiff, even if he had promised, had done no work-given nothing and given up nothing in exchange. ${ }^{16}$ In response, plaintiff's counsel and some of the judges pointed out that the plaintiff's promise had in fact induced the defendant's promise, and vice versa. ${ }^{17}$ If the promises induced each other, the parties themselves have admitted they were sufficient in trade.

And if the parties have admitted them sufficient in trade, that was all law and reason needed. The trade, as the parties had confessed it, could be enforced. Their bargain even suggested a bargain-focused

S. Arnold et al. eds., 1981); David J. Ibbetson, Assumpsit and Debt in the Early Sixteenth Century: The Origins of the Indebitatus Count, 41 CAMBRIDGE L.J. 142, 142 (1982).

9. As reported and translated in J.H BAKER \& S.F.C. MILSOM, SOURCES OF ENGLISH LEGAL HISTORY: PRIVATE LAW TO 1750, at 485 (1986) (from manuscript reports of Anthony Gell).

10. Id. at 485 .

11. Id.

12. Id. at 494-95. The report of West $v$. Stowell is also found at (1578) 74 Eng. Rep. 437. Both Baker \& Milsom's and the English Reports' versions are taken from Leonard's Reports at 2 Leon. 154. Baker \& Milsom report the arguments from 1577.

13. BAKER \& MILSOM, supra note 9, at 494-95.

14. Id. at 495 .

15. Id. at 486 (comparing other considerations which each were "wrong and against the law and reason").

16. Id. at 486-87 ("for the party who undertook ... was to have nothing before obtaining it, and so there was no quid pro quo"); id. at 495 ("Such a reciprocal promise betwixt the parties themselves at the match is sufficient, for there is consideration good enough to each: as, the preparing of the bows and arrows, the riding or coming to the place appointed to shoot, the labour [sic] in shooting, the travail in going up and down . . . . But for the betters by there is not any consideration, if the better doth not give aim.").

17. Id. at 487 (Onslow's refutation of the "time" argument); id. at 495 (Justice Mounson stated, "[H]ere this counter-promise is [a] reciprocal promise, and so a good consideration: for all the communication ought to be taken together."). 
remedy. In support, Justice Mounson noted that, because the plaintiff's promise was reciprocal, the defendant could sue just as the plaintiff could sue. ${ }^{18}$ While that rationale does not work in a wagering case (because only one party could win the bet), it is true in all others, as West recognized ${ }^{19}$ and many courts soon noted. ${ }^{20}$

Even early courts realized that, though the parties traded promises, what the parties really wanted was the counterparty's performance, so the courts made another argument: The law had always enforced a promise given in exchange for a performance. In that case, the party performing had to trust the party promising, and that trust resulted in an enforceable promise. But if both parties were willing to trust to each other's promises, who is the court to deny the validity of that trust, or to deny it on one side but not the other? In other words, if promise-induced trust was sufficient for the parties to make one promise enforceable, it should make another equally so. ${ }^{21}$

Lucy won his case, ${ }^{22}$ and a promise was later deemed consideration in a wagering case. ${ }^{23}$ (Wagers may remain unenforced on other public policy grounds.) ${ }^{24}$ Before long (from 1579 on), courts were stating this new general principle: A reciprocal or mutual promise was a good consideration. ${ }^{25}$ The law has never looked back.

18. Id. at 495 .

19. Id. The defendant's objection was that, in this mutual promise case, "the promise of the plaintiff to the defendant non parit actionem ... upon which the defendant could not have an action against the plaintiff." Id. (citation omitted). Justice Mounson's reply is that, if Stowell had won the bet, there would indeed be a reciprocal action. See $i d$. ("Wherefore, then, is there not here a reciprocal action?").

20. See Nicholas v. Raynbred (1615) 145 Eng. Rep. (Jenk.) 215 (“[M]utual assumpsits are a good consideration, and each of them has a remedy against the other."); Wichals v. Johns (1599), 78 Eng. Rep. 938 (K.B.) (“[T]here is a mutual promise . . . so that if the plaintiff doth not pay it . . . the defendant may have his action against him."); Anon (K.B. 1579), L.I. MS Misc. 488, at 61, reported in J.H. BAKER, THE LEGAL PROFESSION AND THE COMMON LAW 383 n.48 (1986) ("equall remedie").

21. See, e.g., Bettisworth v. Campion (1608) 80 Eng. Rep. 90 (K.B.) (“[C]onsideration on each part was the mutual promise [of] the one to the other."); see also II WILLIAM Fulbecke, A Parallele or Conference of the Civil LaW, The Canon LaW, AND the COMMON LAW OF THIS REALME OF ENGLAND 18 (1618) ("[O]ur Law requireth in all contractes a mutuall consideration, and one part of the contract challengeth and begetteth the other.").

22. BAKER \& MILSOM, supra note 9 , at 487.

23. E.g., Andrews v. Herne (1661) 83 Eng. Rep. 283; Walcot v. Tappin (1661) 83 Eng. Rep. 808.

24. See Blaxton v. Pye (1766) 95 Eng. Rep. 828 (extending statutes to forbid recovery); see also Weisbrod v. Fremont Hotel, Inc., 326 P.2d 1104, 1104 (Nev. 1958) (holding as common law, on policy grounds, that "an action does not lie for the collection of money won in gambling”), superceded by statute as recognized in Sigel v. McEvoy, 707 P.2d 1145, 1146 (Nev. 1985).

25. See cases listed at Ibbetston, supra note 1, at 85 n.104. 
What a marvelous development! Giving legal force to mutual promises democratized contract law. ${ }^{26}$ This development credits exchanging parties' own judgment of what their trust is worth. It encourages both mutual trust and trustworthy action. It empowers even the poorest individual to start with nothing and barter future work for real value. It allows courts to give force of law not just to a standardized set of property transfers but to the subjective intent of the parties that is expressed in the great variety of what they might promise to do. ${ }^{27}$ This decision was, with hindsight, the most important and the furthest leap forward in our contract law.

26. As actions on plebian mutual promises took root, the property-owning aristocracy became so bothered at being bound on their informal promises that Parliament passed the Statute of Frauds to cut back on their potential liability. See SIMPSON, supra note 1, at 599$605,609-12$.

27. Note that doctrines of assent did not exist in contract law until the early $1800 \mathrm{~s}$ and still play no necessary analytical role other than to pinpoint the moment that both promise and consideration exist. Val Ricks, Assent Is Not an Element of Contract Formation, 61 U. KAN. L. REV. 591 (2013) (proving the point with exhaustive arguments and good humor); see also OLIVER WENDELl HOLMES, THE COMMON LAW 305 (1880) ("The question when a contract is made arises for the most part with regard to bilateral contracts by letter," Holmes says in a brief introduction to his only discussion, two brief paragraphs long, of offer and acceptance, following a chapter-long lecture on promise and consideration). 
III. The Worst of Contracts CASES 


\section{Asmus v. Pacific Bell and the "Unilateral" Employment Contract: Building the House of Cards Higher}

\section{RACHEL ARNOW-RICHMAN ${ }^{*}$}

Of all the murky areas of contract law, employment law may be the worst. Courts struggle to apply static principles of assent and consideration to long-term, at-will, and inherently unequal relationships, making a mess of traditional doctrine. ${ }^{1}$ Nowhere is the task thornier (or the analysis poorer) than in handbook modification cases.

Asmus v. Pacific Bell involved Pacific Bell's discontinuance of a binding employment security policy that promised managers retraining and reassignment in the event of job elimination. ${ }^{2}$ The policy stated that it would remain in effect absent a material change affecting the company's business plan. ${ }^{3}$ After six years and several warnings, Pacific Bell replaced the policy with an incentivized lay-off program and enhanced benefit package for continuing employees. ${ }^{4}$ The plaintiff (employees) sued for breach of the original policy. ${ }^{5}$

Pacific Bell argued that, although no material change had occurred, it could unilaterally terminate the policy rather than negotiate a modification with covered employees. ${ }^{6}$ The California Supreme Court agreed, holding, on certified question, that an employer may unilaterally terminate a contractual personnel policy "as long as its action occurs after a reasonable time, and is subject to . . . implied limitations, including reasonable notice."

As a practical matter, this is not a bad result. The premise that employee handbooks can become contractual is a stretch. Courts talk of handbooks as "offers" that employees "accept" through continued employment, ${ }^{8}$ but there is neither an intent to be bound nor any

* Chauncey Wilson Memorial Research Professor \& Director, Workplace LawProgram, University of Denver, Sturm College of Law. Thanks to J.H. ("Rip") Verkerke for sharing his insights on handbook modification over several enjoyable conversations and to J. Kirk McGill for excellent research assistance on this contribution.

1. See generally Rachel Arnow-Richman, Foreword: The Role of Contract in the Modern Employment Relationship, 10 TEX. WESLEYAN L. REV. 1, 2-5 (2003) (describing these challenges and their idiosyncratic results).

2. Asmus v. Pacific Bell, 999 P.2d 71, 73 (Cal. 2000).

3. The policy included language that it would "be maintained so long as there is no change that will materially affect Pacific Bell's business plan achievement." Id.

4. Id. at $73-74$.

5. Id. at 74 .

6. Id. at $73-74$.

7. Id. at 81 .

8. See, e.g., Sanchez v. Life Care Ctrs. of Am., Inc., 855 P.2d 1256, 1258 (Wyo. 1993); Woolley v. Hoffman-La Roche, Inc., 491 A.2d 1257, 1265-68 (N.J. 1985), modified, 499 A.2d 515 (1985); Pine River St. Bank v. Mettille, 333 N.W.2d 622, 625-26 (Minn. 1983). 
awareness of an exchange. ${ }^{9}$ The leap is justified as a way of enforcing employees' reasonable expectations while policies are in effect, but, unsurprisingly, courts draw the line at foreclosing managerial discretion to prospectively change course. ${ }^{10} \mathrm{~A}$ rule that gives the employer that power, while biding employees time to adjust, does just that.

Rather than acknowledge this, however, Asmus sought to rationalize its conclusion doctrinally, butchering the law in the process. The "general rule governing . . . unilateral contracts[,]" it asserted, "is that [the promisor may] after a reasonable time . . . terminate or modify the contract ... with reasonable notice of the change[;] additional consideration is not required." 11

The layers of dysfunction in this statement are almost too deep to parse. Start with the court's basic misunderstanding of unilateral contracts. In a unilateral contract, the promisor offers consideration in exchange for a specific act, and the offeree can accept only by taking such action. ${ }^{12}$ By definition, such contracts cannot be terminated or modified, as they form and are performed simultaneously. ${ }^{13}$ If, as the court assumed, Pacific Bell's original policy was an "offer" for a unilateral contract and the employees "accepted" by forbearing to quit, then it was too late to terminate or modify: the employees performed by remaining on the job, and the employer was bound by its promise. ${ }^{14}$

A better way to look at it, more consistent with probable intent, is that Pacific Bell was seeking continuing employment, not a one-time

9. As explained by the Michigan Supreme Court in the seminal case recognizing the enforceability of employee handbooks:

[W]here an employer chooses to establish such [personnel] policies . . . t] he employer secures an orderly, cooperative[,] and loyal work force, and the employee the peace of mind associated with job security and the conviction that he will be treated fairly. No pre-employment negotiations need take place and the parties' minds need not meet on the subject. ... It is enough that the employer chooses, presumably in its own interest, to create an environment . . "instinct with an obligation."

Toussaint v. Blue Cross \& Blue Shield of Mich., 292 N.W.2d 880, 892 (Mich. 1980); see generally Stephen F. Befort, Employee Handbooks and the Legal Effect of Disclaimers, 13 INDUS. REL. L.J. 326, 343 (1993) (describing the "notion of a bargained-for exchange in [the handbook] setting" as a "convenient and understandable [fiction]").

10. See Bankey v. Storer Broad. Co., 443 N.W.2d 112, 120 (Mich. 1987) (asserting that although employees "expect that a discharge-for-cause policy will be uniformly applied while it is in effect . . . . The very definition of 'policy' negates a legitimate expectation of permanence").

11. Asmus, 999 P.2d at 81 .

12. 1-1 CORBIN ON CONTRACTS $§ 1.23$ (2017).

13. See id.

14. See Asmus, 999 P.2d at 89 (George, C.J., dissenting) (invoking preexisting legal duty principles to conclude that Pacific Bell could not alter its job security policy without obtaining employee assent and supplying new consideration). 
forbearance. ${ }^{15}$ A promisor who has a change of heart can theoretically revoke an offer for a unilateral contract prior to full performance because technically the offer has yet to be accepted. ${ }^{16}$ But if performance has begun, the law requires a promisor to hold the offer open, allowing a reasonable time for completion so as to avoid injustice to the promisee. ${ }^{17}$ This would mean that following the employees' forbearance, Pacific Bell had to maintain its policy for however long it would reasonably take to receive the full benefit of continued employment sought by its promise.

Ah, there's the catch. The "performance" in this so-called unilateral contract had no specified duration. Under employment at will, employees can stay for as long or as little as they like. Some have said that this makes employment relationships illusory, but the better understanding is that they are simply indefinite. ${ }^{18}$ Parties typically enter employment with the hope, if not the guarantee, of a longterm outcome. ${ }^{19}$ Along the way, they implicitly agree to be bound to reasonable, albeit fluctuating, terms, such as Pacific Bell's security policy. It is a quintessential relational contract. ${ }^{20}$

This insight brings down the curtain on the unilateral contract charade. Committing to a job is nothing like crossing a bridge or climbing a flagpole. ${ }^{21}$ Employment should instead be analyzed like

15. See Bankey, 443 N.W.2d at 116 (describing the latter characterization as "strikingly artificial" because "[f]ew employers and employees begin each day contemplating whether to renew or modify the employment contract in effect at the close of work on the previous day").

16. 1-3 CORBIN ON CONTRACTS $\$ 3.9$ (2017).

17. See RESTATEMENT (SECOND) OF CONTRACTS $§ 45$ (AM. LAW INST. 1979) (stating that under such circumstances "an option contract is created" with "[t]he offeror's duty of performance ... conditional on completion or tender of the invited performance.").

18. Contemporary contract law eschews any requirement of "mutuality of obligation," in the sense of equivalent commitments. RESTATEMENT (SECOND) OF CONTRACTS $\S$ 79 (AM. LAW INST. 1981). Moreover, the notion of illusoriness is inconsistent with courts' characterization of the employment relationship as unilateral. See 2-6 CORBIN ON CONTRACTS $\$ 6.2$ (2017) ("[W]here the employer . . . promise[s] job security through restrictions on the power to terminate ... the employee's services provide consideration for a unilateral contract. . . The employee is not bound, but the employer is bound. There is no mutuality of obligation, but there is consideration.").

19. Indeed, this is one of the factors that distinguishes employment from increasingly common independent contractor relationships that presume a short-term arrangement. See, e.g., Love v. JP Cullen \& Sons, Inc., 779 F.3d 697, 702 (7th Cir. 2015) (including length of commitment among factors determining existence of employer-employee relationship for statutory coverage purposes); RESTATEMENT (SECOND) OF AGENCY § 220 (1958) (same under common law agency principles).

20. See generally Marion Crain, Arm's-Length Intimacy: Employment as Relationship, 35 WASH. U. J.L. \& POL'Y 163 (2011); Robert C. Bird, Employment as a Relational Contract, 8 U. PA. J. LAB. \& EMP. L. 149 (2005); Paul J. Gudel, Essay, Relational Contract Theory and the Concept of Exchange, 46 BUFF. L. REV. 763 (1998).

21. See Rachel Arnow-Richman, Mainstreaming Employment Contract Law: The Common Law Case for Reasonable Notice of Termination, 66 FLA. L. REV. 1513, 1567 (2014) (exploring and rejecting this analogy to formulaic unilateral contract scenarios). 
other long-term bilateral contracts that are terminable at will. ${ }^{22}$ At a minimum, terms that purport to be contractual should be enforced as written. Pacific Bell's policy included an intended duration-it was to be maintained until there was a material financial change. ${ }^{23}$ The company conceded that this had not occurred. ${ }^{24}$ Ignoring the record and the phrasing of the certified question, the court inexplicably failed to hold Pacific Bell to its word, preferring to characterize the policy as one of indefinite duration. ${ }^{25}$

Had the policy actually been indefinite, the court might have been justified in making up its own modification rules. More accurately, the court would have had to imply reasonable termination language to fill the proverbial contractual gap. ${ }^{26}$ Ironically, indefinite bilateral commercial contracts are usually presumed terminable at will, subject to reasonable notice. ${ }^{27}$ In short, the result in Asmus would have been correct had both the facts and the analysis been different.

Fortunately, the practical fallout from Asmus is likely to be limited. Most handbook policies are indefinite; few employers are willing to box themselves in like Pacific Bell. This means that courts applying Asmus will generally reach the right result on the facts before them. Sadly though, they will also continue to abuse unilateral contract doctrine in the process, rehashing the court's tortured application.

To be fair, the California Supreme Court is hardly the first court to presume that employment is a unilateral contract. That is a long entrenched-though highly inapt-judicial approach. ${ }^{28}$ One cannot fault Asmus for the house of cards that is employment contract law. If only the court had not built it so high.

22. See id. at 1563-67 (justifying this re-characterization); Rachel Arnow-Richman, Modifying At-Will Employment Contracts, 57 B.C. L. REV 427, 479-80 (2016) (same).

23. Asmus v. Pacific Bell, 999 P.2d 71, 73 (Cal. 2000).

24. Id. at 74 .

25. Id. at 80 . The dissent would have decided the case based on the material alteration clause contained in the original policy. Id. at 84-89 (George, C.J., dissenting).

26. Contemporary contract law declines to void contracts for indefiniteness where there is intent to be bound and a basis for crafting a remedy. See RESTATEMENT (SECOND) OF CONTRACTS $\S 33(2)$ (AM. LAW. INST. 1981); U.C.C. § 2-204(3) (AM. LAW INST. \& UNIF. LAW COMM'N 2017). A vast literature exists as to how courts should supply the missing terms in such "incomplete" agreements. See 6-26 CORBIN ON CONTRACTS $§ 26.4$ (A) (summarizing key theories).

27. See U.C.C. § 2-309(3) (AM. LAW InST. \& UNIF. LAW COMM'N 2017); cf. ArnowRichman, Mainstreaming, supra note 21, at 1547-48 (asserting that reasonable notice is the proper "gap-filler" under common law consistent with the UCC).

28. See Mark Pettit, Jr., Modern Unilateral Contracts, 63 B.U. L. REV. 551 (1983) (tracing application of unilateral contract theory to employment relationships to early twentieth century decisions enforcing employer promises of pension benefits otherwise deemed gratuitous). 
What is the Sound of One Form Flapping?: Hill v. Gateway 2000, Inc. and the Deconstruction of Individual Autonomy

\section{DANIEL D. BARNHIZER*}

Hill v. Gateway 2000, Inc. ${ }^{1}$ is a fantastically awful decision. Legally, Judge Frank Easterbrook's analysis and reasoning ${ }^{2}$ either ignore or grossly mischaracterize the law in several respects. Practically, Hill (along with its partner-in-crime, ProCD v. Zeidenberg) ${ }^{3}$ led later courts to rewrite the law of sales, particularly with respect to consumer transactions. ${ }^{4}$ Pedagogically, this decision has been justifiably ridiculed as meriting an " $\mathrm{F}$ " if it were presented on a law school exam. ${ }^{5}$ Judicially, and from a Rule of Law perspective, this case demonstrates the ability of judicial ego and a desire to shape the law to the judge's own preferences to produce unintended consequences and incoherence in the law. On every level, Hill is a bad decision.

But is this enough to count Hill among the "worst ever"? One indication of the special power of Hill, and its companion ProCD, to take the title of "worst ever" is its ability to create common ground in any meeting of contracts scholars, regardless of jurisprudence or ideology. In my own experience at contract law conferences, for instance, there are often lively moments (reminiscent of many a post-presidentialelection Thanksgiving feast) when discussion threatens to break down over the realization that world views at the table are, in fact, quite heterogeneous. Tempers flare in the passive-aggressive manner of tenured academics. Faces redden; words are said. And the unten-

* Professor of Law, Bradley Stone Faculty Scholar, Michigan State University College of Law. Thanks to Research Assistant Nina Lucido and Research Librarian Allison Eicher for their assistance in preparing this essay.

1. 105 F.3d 1147 (7th Cir. 1997) (Easterbrook, J.).

2. Id. While Judge Easterbrook deserves particular condemnation for authoring Hill, it should never be forgotten that the panel-including Judge Walter Cummings and Judge Harlington Wood, Jr.-also joined this opinion and merit some culpability.

3. 86 F.3d 1447 (7th Cir. 1996) (Easterbrook, J.).

4. See Oren Bar-Gill, Omri Ben-Shahar \& Florencia Marotta-Wurgler, Searching for the Common Law: The Quantitative Approach of the Restatement of Consumer Contracts, 84 U. CHI. L. REV. 7, 18-25 (2017) (empirical analysis of the dominance of the shrinkwrap enforcement approach propounded by ProCD and Hill).

5. See Roger C. Bern, "Terms Later" Contracting: Bad Economics, Bad Morals, and a Bad Idea for a Uniform Law, Judge Easterbrook Notwithstanding, 12 J.L. \& POL'Y 641, 643 (2004) (citing Listserv Comment by Professor Stewart Macaulay, University of Wisconsin School of Law, Common Sense and Contracts Symposium: The Gateway Thread - AALS Contracts Listserv, 16 TouRo L. REV. 1147, 1148 (2000) (opining that Easterbrook's analysis in ProCD and Hill "gets an 'F" as a law exam")). Notably, one of my essay questions on previous contracts and sales \& leases exams quotes from the portion of ProCD quoted in Hill and directs students to explain the flaws in Judge Easterbrook's reasoning in light of the text of section 2-207 of the UCC and the official comments. I consider this to be an easy question for my students, and their ability to catalog Judge Easterbrook's errors in 20 minutes or less tends to confirm that opinion. 
ured and/or new scholars look on in horror, perhaps fearing that in any moment someone will suggest pistols at dawn behind the Starbucks. And then a still, small voice pipes up, "Yes, but what about Hill v. Gateway?" Relief crashes the table in the same way as "How 'bout dem Bears?" turns Trump and Clinton voters with drawn silverware back into guffawing family. Regardless where one stands in the continuum of contracts jurisprudence, Hill gives everyone something to hate. ${ }^{6}$ And, at least for academics, ${ }^{7}$ we are united in our love of hating Hill.

The facts of Hill are fairly basic: the Hills saw an advertisement for a Gateway computer claiming certain specifications for $\$ 4,009 .^{8}$ They then phoned Gateway to order the advertised computer and paid for the computer over the phone by credit card. ${ }^{9}$ Gateway shipped the computer, placing inside the box additional terms that included both an arbitration clause and a claim that the Hills would be deemed to have accepted the additional terms unless they returned the computer within 30 days. $^{10}$ The computer did not conform to the advertised specifications, and the Hills sued for breach of contract, fraud, federal Racketeer Influenced and Corrupt Organizations Act violations, and Magnuson-Moss Warranty Act violations. ${ }^{11}$ The trial court permitted most of the Hills' claims to proceed as a class action. ${ }^{12}$

On appeal, the Seventh Circuit panel reversed the district court, with Judge Easterbrook opining that the contract did not form until the Hills failed to reject the nonconforming computer within 30 days. ${ }^{13}$ Thus, according to Judge Easterbrook, the trailing arbitration clause was both part of the contract and enforceable. Although it is impossible to detail all of Judge Easterbrook's errors of law in this short essay, ${ }^{14}$ one howler stands out in particular. Most egregiously,

6. See David A. Hoffman, From Promise to Form: How Contracting Online Changes Consumers, 91 NYU L. REV. 1595, 1603 (2016) ("Indeed, Hill may be the most criticized contracts case of the last twenty-five years.").

7. Courts, on the other hand, have unfortunately ignored scholarly preferences for coherence and sound legal analysis and reasoning, and, with few exceptions, the majority of courts addressing shrinkwrap and money-now-terms-later contract formations have embraced Hill and ProCD. See Bar-Gill et al., supra note 4, at 21-22 ("In the past eleven years, courts have embraced shrinkwrap contracting in all twenty-four cases in which they have had to address the issue.").

8. Hill v. Gateway 2000, Inc., No. 96C4086, 1996 WL 650631, at *1 (N.D. Ill. 1996). Gateway only charged the Hills $\$ 3,689$, reflecting later price reductions by Gateway. Id.

9. Id.; see also Hill v. Gateway 2000, Inc., 105 F.3d 1147, 1148 (7th Cir. 1997).

10. Id. at 1148 .

11. Hill, 1996 WL 650631 , at *1.

12. Id. at $* 7$.

13. Hill, 105 F.3d at 1150 .

14. Many others have also catalogued those errors. In my opinion, Roger Bern's analysis is one of the best and most complete analyses. See Bern, supra note 7, at 688-753. Other excellent and trenchant critiques include Robert A. Hillman, Rolling Contracts, 71 FORDHAM L. REV. 743, 752-55 (2002) (critiquing errors in Hill with respect to sections 2- 
in determining that the contract between the Hills and Gateway did not form until after the Hills failed to return the computer for 30 days, Judge Easterbrook summarily rejected the argument that the trailing terms in the computer box were controlled by section 2-207 of the Uniform Commercial Code (UCC). Citing ProCD, Judge Easterbrook performs a "Wizard of $\mathrm{Oz}$ " sleight of hand as he demands we not look behind the curtain:

Plaintiffs tell us that ProCD came out as it did only because Zeidenberg was a "merchant" and the terms inside ProCD's box were not excluded by the "unless" clause [of Uniform Commercial Code $\S 2-207(2)]$. This argument pays scant attention to the opinion in ProCD, which concluded that, when there is only one form, "sec. 2-207 is irrelevant." The question in ProCD was not whether terms were added to a contract after its formation, but how and when the contract was formed. ${ }^{15}$

To anyone - including first-year law students-with passing familiarity with section 2-207, both these statements are patently absurd. With respect to the first statement-that section 2-207 is irrelevant where there is only one form - section 2-207(1) expressly contemplates not merely situations involving the typical "battle of the forms," but also communications (including forms) that follow oral agreements by the parties. ${ }^{16}$ As the Official Comment notes, section 2-207:

206 and 2-207 of the UCC); Jean Braucher, Delayed Disclosure in Consumer E-Commerce as an Unfair and Deceptive Practice, 46 WAYNE L. REV. 1805, 1819-27 (critiquing Hill analysis of section 2-207 of the UCC and Magnuson-Moss Warranty Act); William H. Lawrence, Rolling Contracts Rolling Over Contract Law, 41 SAN DIEGo L. REV. 1099, 1101-04 (2004); Deborah W. Post, Dismantling Democracy: Common Sense and the Contract Jurisprudence of Frank Easterbrook, 16 TOURO L. REV. 1205, 1214-31 (2000) (critiquing Judge Easterbrook's characterization of consumer expectations and the mores of the marketplace in

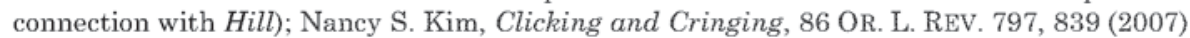
(critiquing Judge Easterbrook's holding in ProCD that "turned [U.C.C. §204(1)] on its head so that the parties' conduct no longer established the existence of the agreement"); Franklin G. Snyder, Commercial Calamities: Clouds of Mystery: Dispelling the Realist Rhetoric of the Uniform Commercial Code, 68 OHIO ST. L.J. 11, 31 (2007) (critiquing the Seventh Circuit's habitually loose interpretation of section 2-207 of the UCC as seen in Hill); Danielle Kie Hart, Contract Formation and the Entrenchment of Power, 41 LOY. U. CHI. L.J. 175, 209-14 (2009) (criticizing Judge Easterbrook's test put forth in Hill and ProCD, which was used to determine whether a contract was formed, as essentially eliminating a plaintiffs ability to bring claims that relied on expanded policing doctrines); Wayne R. Barnes, Toward a Fairer Model of Consumer Assent to Standard Form Contracts: In Defense of Restatement Subsection 211(3), 82 WASH. L. REV. 227, 272 (2007) (arguing that courts should not enforce standard form contracts beyond what a consumer would expect, which is contrary to Judge Easterbrook's holdings). Cf. W. David Slawson, Contractual Discretionary Power: A Law to Prevent Deceptive Contracting by Standard Form, MiCH. ST. L. REV. 853, 881 (2006) (describing the arbitration clause in the contract between the Hills and Gateway as an invalid exercise of Gateway's contractual discretionary power, thus making it unenforceable).

15. Hill v. Gateway 2000, Inc., 105 F.3d 1147, 1150 (7th Cir. 1997) (citing ProCD, 86 F.3d at 1452) (emphasis added) (citation omitted).

16. U.C.C. $\$ 2-207$ provides: 
[I] s intended to deal with two typical situations. The one is the written confirmation, where an agreement has been reached either orally or by informal correspondence between the parties and is followed by one or both of the parties sending formal memoranda embodying the terms so far as agreed upon and adding terms not discussed." ${ }^{17}$

As to the second statement-section 2-207 deals both with contract formation and how to treat the additional or different terms that arise. ${ }^{18}$ This is not complex legal analysis; ${ }^{19}$ it is basic reading skills, and Judge Easterbrook runs through it like a tornado in a trailer park.

The true awfulness of Hill lies not in the errors, but in Judge Easterbrook's hubristic celebration of pet policies as triumphant over the actual law. Lenora Lewdon perfectly captured the dilemma this creates for teachers of contract law when confronted by students asking whether "common sense" informs contract law and the enforceability of promises. ${ }^{20}$ The better answer, Lewdon suggests, is another question: "whose common sense is this?"21 Judge Easterbrook forces us to teach our students a harsh lesson, and one that we wish we could shove off as an aberration. Hill is good law in many jurisdictions because, in my opinion, business-friendly courts can use it to justify a streamlined rule that in practical terms affects only the method, rather than the substance, of the terms businesses can im-

(1) A definite and seasonable expression of acceptance or a written confirmation which is sent within a reasonable time operates as an acceptance even though it states terms additional to or different from those offered or agreed upon, unless acceptance is expressly made conditional on assent to the additional or different terms.

(2) The additional terms are to be construed as proposals for addition to the contract. Between merchants such terms become part of the contract unless ....

17. U.C.C. \$ 2-207, cmt. 1 (AM. LAW INST. \& UNIF. LAW COMM’N 2017) (emphasis added).

18. U.C.C. § 2-207(1), (2) (AM. LAW INST. \& UNIF. LAW COMM’N 2017).

19. To the extent that unraveling contract formation issues in the context of a seller's attempt to introduce new terms by sending them with the goods only after the parties agreed on the transaction, Judge Easterbrook still has no valid excuse. This fact situation had been addressed explicitly in cases such as Step-Saver Data Systems, Inc. v. WYSE Technology, 939 F.2d 91 (3d Cir. 1991), which examined carefully each of the relevant UCC provisions on contract formation (including section 2-207). In ProCD, Judge Easterbrook brushes off Step-Saver by asserting, albeit incorrectly, that ProCD involved consumers rather than merchants (without noting that nonmerchants receive greater protection under section 2-207(2) of the UCC than do merchants), and that Step-Saver was a battle of the forms case while ProCD involved only one form. See ProCD, Inc. v. Zeidenberg, 86 F.3d 1147, 1148 (7th Cir. 1997). Judge Easterbrook's mischaracterization of precedent and section 2-207 is the judicial equivalent of the playground ploy of placing one's fingers in one's ears and chanting "Nyah, nyah, nyah, I can't hear you."

20. Lenora Ledwon, Common Sense, Contracts, and Law and Literature: Why Lawyer Should Read Henry James, 16 Touro L. REV. 1065, 1066-67 (2000).

21. Id. 
pose on their customers. ${ }^{22}$ But that only makes our job more difficult in attempting to teach our students respect for law, respect for the work of the courts, and respect for the Rule of Law. These principles fall victim to Judge Easterbrook's willingness to ignore the law in favor of his preferred policy outcome.

22. I have to emphasize here that, unlike many, I quite like business-friendly courts. On the other hand, I like even more the Rule of Law, coherent doctrine, and the ability to present a narrative that judges at least try to follow the law. 


\section{Webb v. McGowin: The Perils of "Result-oriented" Jurisprudence}

\section{SCOTT J. BURNHAM*}

No case better exemplifies "result-oriented" jurisprudence than Webb v. McGowin. ${ }^{1}$ Everyone wants Webb to win. You want him to win. I want him to win. We can even hear the deceased promisor screaming from the grave, "Give the poor bastard the money!" And of course the judges want him to win. The only problem is that to get him to win, the court has to torture poor contract law beyond recognition. ${ }^{2}$

Because the case arose on a motion to dismiss, the court takes the facts from Webb's brief-but it is hard to swallow them whole. ${ }^{3}$ According to this version of reality, Webb, an employee of McGowin's logging business, was in a loft when he inadvertently threw a 75pound block of wood directly in the path of the unwary McGowin. Without hesitation, Webb flung his own body at the block, thus diverting it from McGowin, but injured himself in the process. ${ }^{4}$ The grateful McGowin promised to pay Webb $\$ 15$ every two weeks until he (Webb) died, and the payments were in fact made until McGowin died. Subsequently, the dirty executors refused to continue to pay, and Webb sued. ${ }^{5}$

This case is difficult pedagogically because law students seem to swallow the analysis whole, apparently nodding amiably as they read

* Professor Emeritus, Gonzaga University School of Law.

1. 168 So. 196 (Ala. Ct. App. 1935), cert. denied, 168 So. 199 (Ala. 1936).

2. I realize I am assuming here that torture is bad, an assertion with which some of my colleagues may not agree. See Torture Memos, WIKIPEDIA, https://en.wikipedia.org/wiki/ Torture_Memos [https://perma.cc/W4MD-F8EK].

3. For background of the case, including a more credible account of what happened, see Richard DANZIG \& GEOFFrey R. WATson, THE CAPABILITy PRoblem in Contract LAW: FURTHER READINGS ON WELL-KNOWN CASES 149-82 (2d ed. 2004).

4. I pose alternate facts-which seem more consistent with the court's reasoningfor my students to consider:

Webb (up in the loft, shouting): Yo, McGowin!

McGowin (on the ground, looking around, befuddled): Huh?

Webb: It's me, Webb, up in the loft.

McGowin: Ah, there you are. Hey, Webb, is that a big block of wood I see headed directly toward my person?

Webb: Yes, it is. But I tell you what. If you give me $\$ 10$ every week until I die, I will interpose my own body between you and the block, thus diverting it and saving your life, at considerable risk to my own.

McGowin (ever the negotiator): Make it $\$ 15$ every two weeks.

Webb: Deal! (scene ends as he jumps).

5. Webb, 168 So. at 197 . 
it. What the students fail to grasp is that almost every word of this opinion is wrong as it proceeds with unassailable logic from its faulty premise to its foregone conclusion. ${ }^{6}$ Let's break it down:

"Receiving this benefit, McGowin became morally bound to compensate [Webb] for the services rendered." True-but a moral obligation is not a legal obligation.

"Had McGowin been accidentally poisoned and a physician, without his knowledge or request, had administered an antidote, thus saving his life, a subsequent promise by McGowin to pay the physician would have been valid." 8 True-but it is the business of physicians to render services to people, even unconscious people, in the expectation of payment.

"Where the promisee cares for, improves, and preserves the property of the promisor, though done without his request, it is sufficient consideration for the promisor's subsequent agreement to pay for the service, because of the material benefit received." ${ }^{\prime 9}$ Not exactly - the person who cares for the property has a claim for restitution, and the subsequent agreement to pay is superfluous.

"It follows that if, as alleged in the complaint, [Webb] saved J. Greeley McGowin from death or grievous bodily harm, and McGowin subsequently agreed to pay him for the service rendered, it became a valid and enforceable contract." ${ }^{10}$ Completely wrong!

"It is well settled that a moral obligation is a sufficient consideration to support a subsequent promise to pay where the promisor has received a material benefit, although there was no original duty or liability resting on the promisor." 11 Wrong!

'McGowin's express promise to pay [Webb] for the services rendered was an affirmance or ratification of what [Webb] had done raising the presumption that the services had been rendered at McGowin's request." ${ }^{12}$ If so, the presumption can easily be rebutted. ${ }^{13}$

"The averments of the complaint show that in saving McGowin from death or grievous bodily harm, [Webb] was crippled for life. This was part of the consideration of the contract declared on. McGowin was benefited. [Webb] was injured. Benefit to the promisor or injury to the promisee is a sufficient legal consideration for

6. Mary McCarthy famously said of Lillian Hellman, "every word she writes is a lie, including 'and' and 'the.'” See Dick Cavett, Lillian, Mary, and Me, THE NEW YorkER (Dec. $16,2002)$. Wishing to avoid the libel suit that arose from that utterance, note that I inserted the cowardly "almost" in my critique.

7. Webb, 168 So. at 197.

8. Id.

9. Id.

10. Id. at 198 .

11. Id.

12. Id.

13. Cf. the alternate facts, supra note 4 . 
the promisor's agreement to pay." ${ }^{14}$ True-if the benefit or detriment is bargained for. Here, it was not.

When one person rescues another at his or her own peril, it is appropriate that we honor the rescuer, but it is not appropriate for the hero to respond to this outpouring of gratitude by saying, "Thank you; here is my bill." ${ }_{15}$ I think the court in Webb would agree, but it was transfixed by the fact that the rescued party promised to pay, which brings the situation into the twilight zone we cleverly call "promissory restitution." But that fact doesn't make it a contract in the traditional sense of a bargain. We call a promise that is made after performance is rendered "past consideration," which is not consideration. And if there is a valid claim for restitution, the promise is superfluous, because without it the law will deem there to be an "implied-in-law contract," which is not a contract. So, we have neither contract nor restitution.

Nevertheless, it can be argued that the promise to pay does make a difference. The promise serves at least two functions in rescue cases in general, and perhaps a third in this case. First, it undermines the designation of the rescuer's action as a benefit that was conferred gratuitously, because we do not generally promise to pay for gifts. Second, it gives us a way to measure the value of something that otherwise would be difficult to measure. ${ }^{16}$ As with bargained-for consideration, if that is what McGowin thought the act was worth, who are we to question his judgment? ${ }^{17}$ Judge Posner argues that we do not want the law to impose liability on the rescuer for not rescuing, but might we not allow the rescued to freely agree to his or her own liability? ${ }^{18}$

Finally, Webb was injured on the job and may have been entitled to workers' compensation benefits. So, the court might have found elusive consideration when Webb gave up his workers' comp claim in exchange for McGowin's promise that the company would pay for the

14. Webb, 168 So. at 198 .

15. Judge Posner believes that liability would deprive the altruist of the benefit of public recognition. RICHARD A. POSNER, ECONOMIC ANALYSIS OF LAW § 6.9 (7th ed. 2007).

16. Cf. "What can you say about a twenty-five-year-old girl who died?" ERICH SEGAL, LOVE STORY 1 (Harper \& Row 1970).

17. I guess the answer is that we question it if we are an executor, for we do not want the beneficiaries of the estate to claim that we paid debts that were not just debts. Add the executors to our list of those who want Webb to win, or who are at least indifferent to the outcome as long as the court tells them what to do under the legal doctrine known as C.Y.A.

18. Posner, supra note 15. See also William M. Landes \& Richard A. Posner, Salvors, Finders, Good Samaritans, and Other Rescuers: An Economic Study of Law and Altruism, 7 J. LEGAL STUD. 83, 94-95 (1978) ("A legal rule entitling the rescuer to compensation in these situations would be inefficient because it would substitute a costly legal transaction for a costless altruistic exchange."). Or, as Judge Posner put it more succinctly, U^r $=\mathrm{g}\left(\mathrm{W}^{\wedge} \mathrm{r}\right.$ - $\mathrm{C}(\mathrm{y}))+\mathrm{h}\left(\mathrm{W}^{\wedge} \mathrm{v}-(1-\mathrm{p} \hat{\mathrm{r}}) \mathrm{L} 0\right) . I d$. at 94 . 
detriment Webb suffered. ${ }^{19}$ According to the Restatement (Second) of Contracts, the surrender of a claim, even an invalid claim, is consideration for a promise to pay as long as the surrendering party in good faith believes the claim to be valid. ${ }^{20}$

In any event, the result smells more like restitution than contract. Yet the rule has made its way into the Restatement (Second) of Contracts. ${ }^{21}$ In fact, thanks to the bootstrapping of Restatement section 1 , which tells us that a contract is a promise that the law enforces, ${ }^{22}$ since McGowin made a promise and the court enforced it, behold, there is a contract after all! Who says there is no philosopher's stone, magically turning dross into gold?

I sympathize with the problem a court may encounter if it wanted to find for a party but cannot articulate a legal justification. Like the student befuddled by an exam question, the majority in this case throws a barrage of verbiage against the wall in the hope that something sticks. I prefer the honesty of Judge Samford's concurrence, ${ }^{23}$ which says in effect, "What the majority says may be wrong on the law, but it is right on the justice, and I would rather be Valjean than Javert."

19. Webb may have been confused about the entity that made the promise, and the court may have bought into his confusion. Richard Danzig makes clear that the company, not McGowin personally, had made the payments. See DANZIG, supra note 3, at 171-72.

20. RESTATEMENT (FIRST) OF CONTRACTS $§ 76(B)$ (AM. LAW.INST. 1932); RESTATEMENT (SECOND) OF CONTRACTS $§ 74$ (AM. LAW INST. 1982).

21. RESTATEMENT (SECOND) OF CONTRACTS $§ 86$ (AM. LAW INST. 1982).

22. Id. § 1 .

23. Webb, 168 So. at 199 (Samford, J., concurring).

The questions involved in this case are not free from doubt, and perhaps the strict letter of the rule, as stated by judges, though not always in accord, would bar a recovery by plaintiff, but following the principle announced by Chief Justice Marshall . . . where he says, "I do not think that law ought to be separated from justice, where it is at most doubtful," I concur in the conclusions reached by the court. 


\section{Kirksey v. Kirksey \\ ChaRLES CALLEROS* \& VAL RICKS ${ }^{\dagger}$}

Kirksey ${ }^{1}$ is a celebrated pedagogic tool precisely because it is a candidate for the worst decision in contract law. It is poor on its face and even worse in fuller factual context. ${ }^{2}$

\section{Flat On its Face}

Students initially sigh with relief when they see the modest length of Kirksey and discover its simple, plain English. The statement of facts was stipulated by the parties. ${ }^{3}$ The central piece of evidence is a letter from Isaac Kirksey, brother of recently deceased Henry Kirksey, to Henry's widow, Antillico. ${ }^{4}$ In response to the letter, Antillico moved her family and household sixty miles, settled into a comfortable house provided by Isaac, and cultivated a plot of land there. After two years, however, Isaac moved the family to an uncomfortable house in the woods and eventually asked them to leave entirely. ${ }^{5}$

It helps the class to assume that Isaac made a promise with definite terms: to provide a house suitable for raising a family in reasonable comfort, at least until Antillico's children reached adulthood. After partially performing, Isaac breached that promise, which led the jury to award $\$ 200$ in damages to Antillico.

The first-time reader pauses only at the Supreme Court's decision-three terse sentences written by a dissenting Justice. Justice Ormond confuses the reader by commencing with his own dissent, followed by the majority's ruling and disposition in a passage conspicuously lacking in reasoning:

The inclination of my mind, is, that the loss and inconvenience, which the plaintiff sustained in breaking up, and moving to the defendant's, a distance of sixty miles, is a sufficient consideration to support the promise, to furnish her with a house, and land to cultivate, until she could raise her family. My brothers, however think, that the promise on the part of the defendant, was a mere

* Alan A. Matheson Fellow in Law and Professor of Law at Arizona State University's Sandra Day O'Connor College of Law.

$\dagger$ Charles Weigel II Research Professor and Professor of Law at South Texas College of Law Houston.

1. Kirksey v. Kirksey, 8 Ala. 131 (1845).

2. One of us helped unearth a broader factual background. See William R. Casto \& Val D. Ricks, "Dear Sister Antillico ...": The Story of Kirksey v. Kirksey, 94 GEO. L.J. 321 (2006).

3. Kirksey, 8 Ala. at 131, 132 ("The question is presented in this Court, upon a case agreed, which shows the following facts.").

4. Id. Other records show she actually went by "Angelico" or "Gelico." See Casto \& Ricks, supra note 2 , at $328 \&$ n. 22 .

5. Kirksey, 8 Ala. at 131. 
gratuity, and that an action will not lie for its breach. The judgment of the Court below must therefore be reversed, pursuant to the agreement of the parties. ${ }^{6}$

The dearth of reasoning provides a clean slate that facilitates robust class discussion and debate, but it hardly satisfies an appellate court's institutional function of clarifying applicable legal principles. ${ }^{7}$ Moreover, Justice Ormond's statement does not clearly capture his disagreement with the majority. Presumably, the majority would not quibble about whether Antillico's moving her family could provide consideration for Isaac's promise in the right circumstances. But Ormond's reference to "mere gratuity" suggests a finding by the majority that Antillico's moving her household was not an inducement for Isaac's promise; her long and costly move was just a necessary condition to accepting a gift promised by Isaac.

What is the basis of Justice Ormond's disagreement? Is he anticipating a general theory of promissory estoppel by equating Antillico's reliance with consideration when necessary to avoid injustice? The cryptic opinion does not provide an answer, but the best critique of the majority's view is one that squarely confronts its finding of a "gratuity."

When students are assigned to represent either side of this dispute, Antillico's student "lawyers" have little trouble drawing inferences that support a conclusion of reciprocal inducement. No one doubts that the promised lodging induced Antillico to move her household. ${ }^{9}$ In return, Isaac's letter permits an inference that he sought assistance in making his land productive. ${ }^{10}$ Another passage reveals that he sought to meet with Antillico, perhaps to provide the support that society would expect of him; however, he was not free to travel to her location, ${ }^{11}$ so he hoped that Antillico would travel to his. More generally, his expressions of caring for the family ${ }^{12}$ suggest that he might have valued their company.

That other students can present counter-narratives ${ }^{13}$ proves only that the issue of reciprocal inducement turns on debatable infer-

6. Id. at 131-32.

7. See, e.g., Hon. Shirley M. Hufstedler, New Blocks for Old Pyramids: Reshaping the Judicial System, 44 S. CAL. L. REV. 901, 910 (1971).

8. Kirksey, 8 Ala. at 132 .

9. She did so within a month or two after receiving the letter from her brother-in-law. Id.

10. Id. ("I will let you have a place to raise your family, and I have more open land than I can tend.").

11. Id. ("I should like to come and see you, but cannot with convenience at present.").

12. Id. ("I know that your situation is one of grief, and difficulty. You had a bad chance before, but a great deal worse now. . . I f feel like I want you and the children to do well.").

13. For example, Isaac's statement that he had more land than he could tend, rather than implicitly requesting assistance in cultivating the land, might have been intended to reassure Antillico that her occupying the land would not be onerous to him. Id. 
ences. Resolving such a factual matter normally rests with the jury. ${ }^{14}$ Did the majority believe that the issue mainly required clarification of the legal principle of inducement ${ }^{15}$ rather than finding an ultimate fact through interpretation or inference? ${ }^{16}$ Alternatively, did the majority find and honor some agreement by the parties to permit de novo analysis of the facts on appeal $?^{17}$ If so, either of those would constitute an important and nonobvious premise to the majority's decision. The court should have explained.

In sum, it may be unsurprising that Kirksey did not presciently apply an early form of promissory estoppel to protect Antillico's interests. However, considering Antillico's substantial reliance and the injustice that resulted from the breach of her brother-in-law's promise, one could expect much more from the court's analysis of consideration. The facts supported a finding of reciprocal inducement; consequently, assuming proper instructions to the jury, the Alabama Supreme Court should have affirmed the jury verdict. At the least, the Court should have fully explained why it did not.

\section{Flatter in Context}

Fuller context confirms our suspicions: there was a bargain. Isaac was squatting on public lands, waiting for Congress to pass a law giving him a preference to buy those lands at a cheap price. ${ }^{18}$ His rights depended on his improving the land, ${ }^{19}$ though, and he had "more open land than [he] could tend." ${ }^{20} \mathrm{He}$ invited Antillico to hold his place. ${ }^{21}$ She could not allege this publicly, though, because the "preference act," when passed, denied rights to placeholders, ${ }^{22}$ and Antillico wanted the

14. See generally Comm'r v. Duberstein, 363 U.S. 278, 291 (1960) (citing United States v. U.S. Gypsum Co., 333 U.S. 364, 394 (1948)) (holding that federal rules restricting the appellate review of a trial judge's findings of fact apply to the judge's drawing inferences from documents).

15. See Baumgartner v. United States, 322 U.S. 665, 670-77 (1944) (a finding of fraud was not treated as a finding of fact subject to restricted appellate review because it was bound up with the complicated statutory standard of "allegiance" and subject to a special and uncertain standard of proof-so the finding necessarily implicated further refining of legal standards).

16. See Duberstein, 363 U.S. at 284-94 (1960) (noting that the question of whether the transfer of an automobile was gratuitous should be treated as a question of fact subject to restricted appellate review).

17. The last sentence- "pursuant to the agreement of the parties"-might hint at such an agreement; however, it would be remarkable for a state supreme court to alter its normal standards of appellate review on a simple stipulation of the parties. Kirksey, 8 Ala. at 132.

18. Casto \& Ricks, supra note 2, at 335-53.

19. Id. at 342 .

20. Kirksey, $8 \mathrm{Ala}$ at 132 (from Isaac's letter).

21. Casto \& Ricks, supra note 2, at 339-47.

22. Id. at 352 . 
land!23 The local jury, seeing through this, awarded her " $\$ 1.25$ per acre" multiplied by 160 acres, the amount of land allowed by the preference act, to give Antillico a total of $\$ 200$ in damages. ${ }^{24}$ The Alabama Supreme Court did not-or refused to-see this bargain.

The Alabama Supreme Court could have affirmed on reliance grounds. Alabama precedent supported this; ${ }^{25}$ Antillico had occupied the land for over two years. ${ }^{26}$ But reliance was not argued, ${ }^{27}$ and only Justice Ormond seems to have bought it.

Why did this dissenter write the opinion? The court probably assigned the case before argument and did not consider it important enough to reassign. ${ }^{28}$

So, the court deprived a jury of its role; ruled gratuitous what was not; and could have affirmed an award for the poor, ${ }^{29}$ dependent, illiterate $^{30}$ widow $^{31}$ and single mom $^{32}$ but instead ruled for the wealthy, ${ }^{33}$ slaveholding, ${ }^{34}$ litigious $^{35}$ local magistrate ${ }^{36}$ and landowner. ${ }^{37}$ The court never fully explained why it did this; the majority did not see the case as important enough to bother writing an opinion. Poor precedent, indeed! We hope our students see it as an example of what not to do.

23. Id. Of course, Antillico's true motives are unknown; this one is inferred.

24. Id. at 350 .

25. See id. at 368-70.

26. Isaac sent the letter in October 1840, and Antillico brought her children down within a month or two and lived there for a little over two years. Id. at 335, 347-48.

27. Id. at $362-65,370$.

28. Id. at 366 .

29. See id. at 329-30 (recounting Henry's debts at the time of his death, when he and Antillico lived on leased land on which they had held over).

30. See id. at $328 \& \mathrm{n} .25$.

31. On her status, see, e.g., id. at $326 \mathrm{nn} .13-14$.

32. Antillico brought as many as nine children with her when she moved. See id. at $335 \&$ n. 89 .

33. See id. at $332-33$.

34. Id. at $332 \& \mathrm{n} .64,334,371$.

35. See id. at 344 (Isaac appears in eight Alabama Supreme Court opinions from 1845-56).

36. See id. at 350 (Isaac had been a Justice of the Peace).

37. Id. at 331-33, 336-39. 


\section{Peevyhouse}

\section{RICHARD R. CARLSON*}

Peevyhouse v. Garland Coal \& Mining Co. ${ }^{1}$ is reviled in law schools across America. Oklahoma's legislature repudiated the case, ${ }^{2}$ and Oklahoma courts rarely cite it today in any contract case; ${ }^{3}$ nonetheless, Peevyouse remains stuck in the craw of legal academia. Half a century after the court's decision, law professors still use Peevyhouse to dramatize the hazards of strip mining and "economic waste."

Peevyhouse is widely hated for two reasons. First, it seems to authorize a breaching party's refusal to perform exactly what it promised to do for no reason other than an alleged lack of merit in the injured party's purpose in bargaining for a promise. Second, Peevyhouse seems to deny the merit of eccentric, aesthetic, or environmental goals lacking "market value." The blame for these faults does not lie entirely with the court; we should not let the parties or their attorneys off the hook. In the end, Peevyhouse best illustrates what Professors Richard Danzig and Geoffrey Watson called "capability problems": ruts in the road to justice causing a divergence between "the law" and outcome. ${ }^{4}$

The sad outcome in Peevyhouse was presaged by the parties' respective assumptions about the transaction. Obviously, Garland wanted the Peevyhouse land for strip mining, and the Peevyhouses expected to earn royalties. However, Garland retained discretion to decide how much coal would be mined. ${ }^{5}$ Garland paid a $\$ 2,000$ advance against royalties, but there was no guarantee the Peevyhouses would earn anything more. ${ }^{6}$ Garland's main purpose was not necessarily to mine

* Professor of Law, South Texas College of Law Houston.

1. 382 P.2d 109 (Okla. 1962), cert denied, 375 U.S. 906 (1963).

2. Open Cut Land Reclamation Act (OCLRA), now known as the Mining Land Reclamation. OKLA. STAT. ANN. TIT 45, §§ 721-729 (West 2017). The OCLRA's relation to Peevyhouse is discussed in Rock Island Improvement Co. v. Helmerich \& Payne, Inc., 698 F.2d 1075, 1077-78 (10th Cir. 1983). But see Schneberger v. Apache Corp., 890 P.2d 847 (Okla. 1994) (citing Peevyhouse in a water pollution case not subject to the OCLRA).

3. As of May 22, 2017, Westlaw shows that Peevyhouse is cited in 172 law review articles, but only 33 court cases. Many of the court cases cite Peevyhouse in connection with the rules of damages for a nuisance or tort, not breach of contract. Moreover, most of the recent decisions citing Peevyhouse are by courts outside Oklahoma, which suggests the possibility that professors do more harm than good by criticism drawing attention to Peevyhouse.

4. RichaRd DANZIG \& GEOFFrey R. WATson, THE CAPABILITY PROBLEM IN CONTRACT LAW 1-3 (2d ed. 2004). For an illuminating behind-the-scenes expose' of Peevyhouse, see Judith Maute, Peevyhouse v. Garland Coal \& Mining Co. Revisited: The Ballad of Wille and Lucille, 89 NW. U. L. REV. 1341 (1995). Professor Maute's article is the source of many of the facts stated in this article.

5. Id. at 1369 .

6. Id. at $1364,1369$. 
coal; he also wanted the land for the diversion of water from other lands it mined. ${ }^{7}$ If Garland chose to use the land only to divert water from other lands, the lease did not prohibit this decision. ${ }^{8}$

The parties' ideas about the value of the land were vague. Garland would eventually argue that the land was worth $\$ 3,600$ before its operations. ${ }^{9}$ However, in negotiations for the lease, Garland offered an advance of $\$ 3,000$ for expected property damage, ${ }^{10}$ and this amount plus advances against royalties exceeded the estimated value of the land. ${ }^{11}$ One might ask whether Garland should have bought the land instead of leasing it, ${ }^{12}$ but an owner bears the continuing burdens of ownership, including liability for environmental hazards. Moreover, the Peevyhouses had reason not to sell even for a price exceeding market value; the land in question connected other parcels and was indispensable for livestock to pass from one parcel to the next.

The Peevyhouses refused $\$ 3,000$ for anticipated property damage, demanding Garland's promise to repair the land after mining it. ${ }^{13}$ Their main goal was not necessarily aesthetic: the Peevyhouses wanted enough remediation to permit safe passage for livestock. ${ }^{14}$

The performance of the contract was a mess. Garland, acting within its discretion under the contract, mined only enough coal to cover the advance plus $\$ 500 .^{15}$ Garland used the land mainly to divert water from other properties, making its other operations more productive and other lessors richer at the expense of the Peevyhouses. ${ }^{16}$ Garland then refused to restore the Peevyhouse land, which he offered no reason for doing so. ${ }^{17}$ It admitted the

7. Id. at 1358 .

8. The Peevyhouses did not assert or seek to prove that Garland breached any implied duty of effort in mining coal or in using the property in a way inconsistent with mining coal. See id. at 1375 .

9. Estimates of the value of the land vary from $\$ 420$ to $\$ 3,600$, possibly because some estimates account for the recoverable coal and other estimates do not. Peevyhouse v. Garland Coal \& Mining Co., 382 P.2d 109, 118 (Okla. 1962).

10. Maute, supra note 4 , at 1358.

11. The final lease included an advance of $\$ 2,000$ against future royalties. $I d$. at 1365 . Moreover, Garland's profits from the coal mined from the property were at least $\$ 25,000$. Id. at 1367 .

12. Garland did purchase the land of at least one other property owner in the same vicinity. Id. at 1358-59.

13. Id. at 1358,1363 .

14. Id. at 1363,1376 .

15. Id. at $1366-67,1369$.

16. In the ensuing litigation, the Peevyhouses did not allege an implied duty of good faith in exercising discretion over mining operations in a way that defeated the Peevyhouses' expectation of royalties. For a discussion of a possible restitution claim, see Maute, supra note 4 , at $1442-43$.

17. Id. at 1369-70. 
breach. $^{18}$

Bad performance was followed by bad settlement negotiations. Initially, Mr. Peevyhouse demanded just $\$ 500$ for the cost of renting a bulldozer to level the ground himself. ${ }^{19}$ Remarkably, Garland rejected this proposal. ${ }^{20}$ Consequently, relations soured (if they were not quite sour already). The Peevyhouses likely soured first from the lack of expected royalties, and then Garland's inexplicable obstinance in refusing to complete the work and rejecting a very reasonable settlement offer just added to it. The Peevyhouses increased their demands as negotiations went on. Finally, Garland offered the same $\$ 3,000$ that the Peevyhouses had rejected for anticipated damages in the original lease negotiations. ${ }^{21}$ The Peevyhouses now contemplated accepting this sum, but Garland also insisted on a clause leaving the Peevyhouses liable to neighbors for runoff from the land. ${ }^{22}$ This demand was unacceptable to the Peevyhouses, and they sued.

For breach of a promise of services to improve property, damages might be (i) the cost of the amount of work it would take to complete or repair property, or (ii) the diminished value (the property value if the work were properly performed minus the property value as left by the breach). ${ }^{23}$ The cost of completion or repair is usually an injured party's best choice. ${ }^{24}$ It accomplishes what the promisee bargained for, it vindicates a promise of work not designed to yield an increase in market value, ${ }^{25}$ and it is easiest to prove. ${ }^{26}$

At trial, the damages issue proved disastrous for the Peevyhouses. They asked for the cost of completion, which their expert estimated at $\$ 29,000^{27}$ - a far cry from the $\$ 500$ they once demanded, and a bit

18. Peevyhouse v. Garland Coal \& Mining Co., 382 P.2d 109, 111 (Okla. 1962). The Peevyhouses did not allege any other theories of contract law.

19. Maute, supra note 4, at 1369-70. It is not clear why Garland initially rejected this offer to settle for $\$ 500$, nor is it clear whether the Peevyhouses appreciated the actual cost and effort required to repair the land to their satisfaction.

20. Id. at $1369-70$.

21. Id. at 1370 .

22. Id.

23. RESTATEMENT (SECOND) OF CONTRACTS: ALTERNATIVES TO LOSS IN VALUE OF PERFORMANCE $\S 348(2)$ (AM. LAW INST. 1981). The Restatement states that this rule only applies in "construction" cases, although it is not clear that this rule cannot be suitable in other cases involving services other than "construction."

24. Id. at cmt. c.

25. Buyers often purchase things that yield personal pleasure but have no objectively measurable gain in the value of their property, estate, or personhood.

26. Costs are proven by invoices of a substitute contractor if the promisee hired a substitute or by estimates of what the work would cost. In contrast, proof of diminished value often requires a battle of expert appraisers over complex market issues.

27. Maute, supra note 4, at 1345 n.5 (citing Peevyhouse v. Garland Coal \& Mining Co., 382 P.2d 109, 111 (Okla. 1962)). 
farther from Garland's estimate of $\$ 400 .{ }^{28}$ The Peevyhouses presented no evidence of diminished value. ${ }^{29}$ Their attorney's strategy was to deny absolutely the relevance of diminished value. ${ }^{30}$

Garland countered with the "economic waste" theory: If the cost of repairing or completing work is grossly disproportionate to diminished value, a court may award diminished value. ${ }^{31}$ Garland's evidence showed that completing the work would add $\$ 300$ in value to the land..$^{32}$ The Peevyhouses' attorney stuck to his guns; evidence of valuation was absolutely irrelevant. He offered no rebuttal of Garland's evidence of value. ${ }^{33}$

The jury awarded $\$ 5,000$ - which cannot be squared with any theory of the case. The Peevyhouses appealed and Garland crossappealed. A majority of the Oklahoma Supreme Court found that an estimated $\$ 29,000$ cost of completion was "grossly disproportionate" to the $\$ 300$ "economic benefit." ${ }_{44}$ The court revised the damages award to match the only evidence of value: $\$ 300$. Incidentally, $\$ 300$ is one-tenth what Garland offered before signing the lease and again in settlement negotiations. ${ }^{35}$

The court's errors began with its statement of the theory of "economic waste," where it left out important qualifications. First, the court implied that the theory required a comparison of exclusively "economic" benefits. ${ }^{36}$ However, a diminished value might be something other than "economic" in nature. In the words of the Restatement, diminished value includes a "probable loss in value to" the injured party." 37 The "probable" value to the injured party might be a matter of credible aesthetic or subjective tastes. The court did not

28. Maute, supra note 4, at 1379 n.151. It is not clear why these estimates were so divergent. Perhaps the divergence was because of uncertainty about what would constitute full repair of the land under the contract. There was also a difficult issue regarding the location of the property line, which evidently could have greatly affected the cost of completion. Id. at 1369-70, 1378-83.

29. Id. at 1378. Mr. Peevyhouse testified only that the property was "worthless" after the mining operations but would be "excellent pasture" if restored. Id. at 1376. He denied knowing the actual value of the land. Id.

30. Id. at 1378 .

31. See RESTATEMENT (SECOND) OF CONTRACTS $\S 348(2)$ (b) (AM. LAW INST. 1981).

32. Peevyouse v. Garland Coal \& Mining Co., 382 P.2d 109, 112, 114, 118-19 (Okla. 1962).

33. Id. at 118. He subsequently argued-erroneously-that offering rebuttal evidence of value would have waived his objection to the relevance of market value. Id. at 119.

34. Id. at 114. It was disproportionate only if one accepted the Peevyhouses' estimate of $\$ 29,000$ to complete the work; but, adopting Garland's estimate of $\$ 400$ would have done the Peevyhouses little good.

35. At one point, Garland had offered $\$ 3000$ to settle the matter. Maute, supra note 4, at $1369-70$.

36. Id. at 113 .

37. RESTATEMENT (SECOND) OF CONTRACTS $§ 348(2)$ (b), cmt c (AM. LAW INST. 1981). 
necessarily mean to reject this concept of value. It assumed, for lack of evidence to the contrary, that the parties' primary and mutual purpose was the "economical recovery" of coal. ${ }^{38}$ A court cannot account for noneconomic value if the promisee fails to prove the value.

Second, the court failed to recognize a difference between "repair" and "completion." Repair might involve destruction of otherwise good and substantial work and might increase a supplier's costs far above what it reasonably anticipated. In contrast, completion usually involves no more than the work bargained for. Economic waste theory applies better in the former situation than in the latter one. ${ }^{39}$

Most of all, Peevyhouse is an example of the long and winding road from law books to trial litigation in a world where normal people do not always think and act like lawyers, and normal lawyers do not always think and act like law professors. It also illustrates that the quality of a court's analysis, opinion, and conclusion is often severely limited by the record and arguments produced by lawyers.

38. Peevyhouse, 382 P.2d at 112 (emphasis added). The court ignored any aesthetic or environmental value of the property, and it is unclear whether it considered the value of providing a safe passage for livestock.

39. Restatement Section 348(2)(b) allows the possibility that costs of "completion" might still be subject to economic waste theory in the rare case when completion accomplishes nothing of value to the injured party. RESTATEMENT (SECOND) OF CONTRACTS $\S 348$ (2)(b) (AM. LAW INST. 1981). See, e.g., Bowes v. Saks \& Co., 397 F.2d 113, 113 (7th Cir. 1968) (holding that a landlord could not recover the cost of remedial work that was promised by tenants, where the landlord had sold the property to the new owner that did not want the work, and nonperformance of the work did not cause any reduction in value or other loss to landlord). 
Scapegoats and the Common Law: Pinnel's Case, Cumber v. Wane, and the Legal Duty Rule

\section{LARRY T. GARVIN*}

We all are familiar with the legal duty rule: A modification to a contract requires consideration in order to be binding. ${ }^{1} \mathrm{We}$ all know the branch of the rule that applies this rule to agreements to discharge a liquidated claim for less than its full amount. ${ }^{2}$ And we all know how objectionable this rule has become and how vigorously the courts have striven to avoid it. So it is natural that the classic case that gave rise to it-Pinnel's Case ${ }^{3}$ — should take its place here.

Very few contracts doctrines - very few legal doctrines, periodhave provoked judges and commentators to such virulent attacks as has the legal duty rule. It is tempting to string together block quotes from the most perfervid of these and call it quits. Two examples will have to do. Consider these judicial philippics:

The history of judicial decisions upon the subject has shown a constant effort to escape from its absurdity and injustice. . . .

$\cdots$

... [T] here is nothing of principle left in the rule itself. . .

$\cdots$

... It may seem to some persons, not having a great veneration for those institutions of antiquity, for which no reason can be given, that a rule so effectually undermined, and having neither rhyme nor reason to support it, ought to be at once overruled and the whole matter placed upon the footing of reason and common sense. $^{4}$

[The judge's] purpose in prolonging this opinion is to show the bench and bar of Texas how utterly unreasonable and unjust to contracting parties the rule is become, and how like a fetich the courts of this country have bowed down and worshiped around the old dictum out of idolatrous reverence for precedents, and because it smells old and musty, though it has long enough retarded the progressive young genius of American Commerce, and in fact it never should have been born. ... [T] $]$ he writer hopes that, when our supreme court gets even

* Lawrence D. Stanley Professor of Law, Michael E. Moritz College of Law, The Ohio State University. Many thanks to Val Ricks for his generosity and forbearance.

1. RESTATEMENT (SECOND) OF CONTRACTS $\$ 89$ (AM. LAW INST. 1981).

2. What Treitel refers to as "decreasing pacts." SIR GUENTER Treitel, SOME LANDMARKS OF TWENTIETH CENTURY CONTRACT LAW 12, 23 (2002).

3. [1602] 77 Eng. Rep. 237; 5 Co. Rep. 117 a.

4. Harper v. Graham, 20 Ohio 106, 115, 117 (1851). 
as good an opportunity as this, it will bury its skeleton so deep that no lawyer will ever scent it out . ..."

In the optimistic words of the English Law Revision Committee, the legal duty rule "has been shattered by argument and ridicule from the judicial bench." ${ }^{\prime \prime}$ In some courts, no doubt; but in most, the legal duty rule has survived judicial assault. A few recent cases that have applied the rule appear in the margin. ${ }^{7}$ So the legal duty rule is not merely an obnoxious legal relic; it is an obnoxious modern doctrine, and a significant one at that. ${ }^{8}$

Why the legal duty rule is dreadful requires little discussion. ${ }^{9}$ Better to be paid today than to have the right to pursue a claim tomorrow, especially when one's claim may be extinguished in bankruptcy or whittled down by legal fees. Much of the same reasoning applies in another common context: agreements to lower the rent in commercial leases because the tenant is in precarious financial condition. Again, better to collect a lower rent than to have the theoretical right to a higher rent and also have an empty storefront that depresses nearby rents. To be sure, this type of modification is capable of abuse-but economic duress and breach of the duty of good faith are grounds for invalidating coerced modifications. ${ }^{10}$

Pinnel's Case is all but uniformly considered the origin of the legal duty rule. Certainly its age-it dates to 1602 - and its provenancethe opinion was written by Lord Coke-have often been given as reasons to retain the rule. ${ }^{11}$ In particular, the House of Lords decision in Foakes $v$. Beer, the leading case in the United Kingdom on that point, rests heavily on Pinnel's Case. ${ }^{12}$ Lord Blackburn's meticulous opinion declares that the legal duty rule, as stated in Pinnel's Case, was not

5. Shelton v. Jackson, 49 S.W. 415, 419 (Tex. App. 1899).

6. English LaW REVISION COMMitTeE, SiXTH INTERIM REPORT (THE STATUTE OF FRAUDS AND THE DOCTRINE OF CONSIDERATION) 1937, [Cmd.] 5449, at 20, reprinted in The Statute of Frauds and the Doctrine of Consideration, 15 CAN. B. REV. 545, 603 (1937).

7. See, e.g., Morrall v. CitiMortgage, Inc., No. CV 114-086, 2015 WL 800173, at *6 (S.D. Ga. Feb. 25, 2015); CitiMortgage, Inc. v. Crawford, 934 F. Supp. 2d 942, 948-49 (S.D. Ohio 2013); Willamette Mgmt. Assocs., Inc. v. Palczynski, 38 A.3d 1212, 1222-23 (Conn. App. Ct. 2012); Yoches v. City of Dearborn, 904 N.W.2d 887, 897 (Mich. Ct. App. 2017).

8. Though the judge who called the legal duty rule "one of the most important subjects in the whole domain of human relations" may have overstated the point slightly. Hettrick Mfg. Co. v. Barish, 199 N.Y.S. 755, 768 (App. Term 1923) (Mullan, J., dissenting).

9. Representative discussions include SIR JACK BEATSON ET AL., ANSON'S LAW OF CONTRACT 118-19 (30th ed. 2016); 1A ARTHUR LINTON CORBIN, CORBIN ON CONTRACTS $§ 172$, at 107-08 (1963); Friedrich Kessler, Einige Betrachtungen zur Lehre von der Consideration, in 1 FESTSCHRIFT FÜR ERNST RABEL 251, 263-66 (Hans Dölle et al. eds., 1954).

10. Specifically on duress, good faith, and the like, see Varouj A. Aivazian, Michael J. Trebilcock, \& Michael Penny, The Law of Contract Modifications: The Uncertain Quest for a Bench Mark of Enforceability, 22 OSGOODE HALL L.J. 173 (1984).

11. See, e.g., Cunningham v. Irwin, 148 N.W. 786, 787 (Mich. 1914); Jaffray v. Davis, 26 N.E. 351, 352 (N.Y. 1891); Pierce, Butler \& Co. v. Jones \& Son, 8 S.C. 273, 279 (1876).

12. Foakes v. Beer [1884] 9 App. Cas. (HL) 605 (appeal taken from Eng.). 
just dictum-it was a mistake. ${ }^{13}$ Ultimately, though, Lord Blackburn affirmed because, in the views of his colleagues, "longcontinued action on this dictum [was such] as to render it improper in this House to reconsider the question." ${ }^{14}$ The Lord Chancellor was similarly critical, ${ }^{15}$ but he held that the legal duty rule, as set forth in Pinnel's Case:

$[\mathrm{H}]$ as always, since the sixteenth century, been accepted as law. If so, I cannot think that your Lordships would do right if you were now to reverse, as erroneous, a judgment of the Court of Appeal proceeding upon a doctrine which has been accepted as part of the law of England for 280 years. ${ }^{16}$

The other Lords sitting in Foakes $v$. Beer were similarly unenthusiastic about the legal duty rule as such, but they did not think themselves in a position to overturn it. ${ }^{17}$ But for Pinnel's Case, then, Foakes $v$. Beer might well have come out the other way.

So why not put Pinnel's Case into this rogues' gallery? For four reasons, really. First, the so-called "Rule in Pinnel's Case" was not a rule at all; it was dictum. Second, the case did not concern assumpsit-at all. Third, Lord Coke's explanation for this dictum should have made clear that it ought not be carried over into assumpsit. And fourth, contemporary case law was often inconsistent with the "Rule in Pinnel's Case," suggesting that courts of Lord Coke's time did not see Pinnel's Case as courts did a century or more after.

13. In Lord Blackburn's words:

What principally weighs with me in thinking that Lord Coke made a mistake of fact is my conviction that all men of business, whether merchants or tradesmen, do every day recognise and act on the ground that prompt payment of a part of their demand may be more beneficial to them than it would be to insist on their rights and enforce payment of the whole. Even where the debtor is perfectly solvent, and sure to pay at last, this often is so. Where the credit of the debtor is doubtful it must be more so.

Id. at 622 .

14. Id. Note, however, that this issue had never actually come before the House of Lords.

15. In his words,

It might be, and indeed I think it would be, an improvement in our law, if a release or acquittance of the whole debt on payment of any sum which the creditor might be content to receive by way of accord and satisfaction, though less than the whole, were held to be generally binding, though not under seal.

Id. at 613 .

16. Id. at 612 .

17. Lord Watson thought it unnecessary to reach that question (and was in any event unwilling to disturb that doctrine). Id. at 623-24. Lord FitzGerald was much in line with the Lord Chancellor's view: "[T]t would have been wiser and better if the resolution in Pinnel's Case had never been come to .... [But] [w]e find the law to have been accepted as stated for a great length of time, and I apprehend that it is not now within our province to overturn it." Id. at 630 . 
First, the actual holding of Pinnel's Case. As its first sentence states, this was an action of debt-that is, an action on a written and sealed bond. Under the rules of the day, an action on such a bond could not be countered with a defense of performance, for that would allow the bond to be negated by parol..$^{18}$ "Accord and satisfaction" was a defense against an action for debt based on an informal contract because it was permissible to vary an informal contract with something similarly informal. But if performance of the bond was not a defense, then a fortiori performance of a substitute for the bond could not be a defense. Very often, however, the bond itself was framed as a penalty bond with conditional defeasance-for example, if A borrowed $£ 100$ from B with payment due on March 1, the bond might state that A must pay $£ 200$ to B unless he pays $£ 100$ to B by March 1. Then it was possible for the debtor to plead substituted performance of the condition of defeasance. Such a plea would work, however, only if the condition could still be met. After that date, the condition subsequent would have failed, and the penal bond would be in effect - and, as noted, bonds could not be varied by parol evidence.

So what was Pinnel's error? According to Lord Coke, "he did not plead that he had paid the [lesser sum] in . . . full satisfaction (as by the law he ought) but pleaded the payment of part generally; and that the plaintiff . . . accepted it in full satisfaction." ${ }^{19}$ It was not sufficient for the debtor to invite the court to infer payment in full satisfaction; the debtor had to plead it. The actual holding of Pinnel's Case thus had nothing to do with consideration or assumpsit; it turned on a nice point of pleading in debt, and nothing more. All the folderol about horses, hawks, and robes was dictum. ${ }^{20}$

Furthermore, Pinnel's Case itself makes clear why it should be limited to the action for debt. Coke's opinion sets forth three exceptions in its dictum about the impossibility of satisfying a debt with a smaller amount. Each can be read as a means of showing the parties' intent to accept payment in full satisfaction, notwithstanding the debtor's failure to plead satisfaction properly. ${ }^{21}$ Take the first excep-

18. The historical background in this paragraph is drawn from A.W. BRIAN SIMPSON, A History OF THE COMMON LAW OF CONTRACT 101-15 (1975).

19. Pinnel's Case [1602] 77 Eng. Rep. 237, 238; 5 Co. Rep. 117 a, 117 b (footnotes omitted).

20. A point made by many, including Lord Blackburn in Foakes v. Beer, 9 App. Cas. (HL) at 605, 616-17. See, e.g., Sigler v. Sigler, 158 P. 864, 866 (Kan. 1916); C.S. Brackett Co. v. Lofgren, 167 N.W. 274, 275 (Minn. 1918); Frye v. Hubbell, 68 A. 325, 329 (N.H. 1907). Nor was the dictum obvious to the judges of that time-Lord Coke very much included. As James Barr Ames found in his classic article, cases as far back as 1455 held quite the contrary, though there was something of a swing toward what became the "Rule in Pinnel's Case" by the middle of the sixteenth century. James Barr Ames, Two Theories of Consideration, 12 HARV. L. REV. 515, 521-22 (1899).

21. I am indebted to Val Ricks for this point. 
tion: the gift of a "horse, hawk, or robe" in satisfaction of the debt. Coke's rationale was that,

[I]t shall be intended ${ }^{22}$ that a horse, hawk, or robe, \&c. might be more beneficial to the plaintiff than the money, in respect of some circumstances, or otherwise the plaintiff would not have accepted of it in satisfaction. ${ }^{23}$

Coke states here that the proof of the benefit for the creditor is that the creditor chose to accept the debtor's offer in satisfaction. Why else would the creditor accept something different? The same goes for the next exception, based on timing. Full satisfaction cannot be made with less than the full payment or after the stated day, but:

$[\mathrm{T}]$ he payment and acceptance of parcel before the ... day in satisfaction of the whole, would be a good satisfaction in regard of circumstance of time; for peradventure parcel of it before the day would be more beneficial to him than the whole at the day, and the value of the satisfaction is not material. ${ }^{24}$

Again, the creditor's acceptance of the lesser payment at an earlier time permits the court to infer that the creditor accepted in full satisfaction of the debt. The final exception is location:

[S]o if I am bound in 20l. to pay you 10l. at Westminster . . . and you request me to pay you 5l. at the day at York, and you will accept it in full satisfaction of the whole 10l. it is a good satisfaction for the whole: for the expences to pay it at York, is sufficient satisfaction. ${ }^{25}$

Once again, the variant tender is evidence of full payment.

Coke's dictum thus is better read as a catalog of methods of overcoming defective pleadings in an action for debt than it is a rule of substantive contract law. As such, there is no reason to import this discussion of proof into a new cause of action, the action in assumpsit. At the very least, there is no obvious reason why assumpsit should have mirrored debt.

Coke himself distinguished sharply between satisfaction of a debt and an action upon a simple contract. In 1616 he ruled:

[I]f a man be bound to another by a bill in 1000l. and he pays unto him 500l. in discharge of this bill, the which he accepts of accordingly, and doth upon this assume and promise to deliver up unto him his said bill of 1000l. this 500l. is no satisfaction of the 10001 . but yet this is good and sufficient to make a good promise, and up-

22. The word intended should be read to mean understood or interpreted, which were the definitions then current in law. Intend, OXFORD ENGLISH DICTIONARY, http://www.oed.com/ view/Entry/97442?rskey=YOVk76\&result=2\#eid [https://perma.cc/MVX2-4E24].

23. Pinnel's Case, 77 Eng. Rep. at 237; 5 Co. Rep. 117 a.

24. 77 Eng. Rep. at 237-38; 5 Co. Rep. 117 a.

25. 77 Eng. Rep. at 238 ; 5 Co. Rep. 117 a-117 b. 
on a good consideration, because he has paid mony,(s) five hundred pound, and he hath no remedy for this again. ${ }^{26}$

And there was authority to this effect even before Pinnel's Case. In Reynolds $v$. Pinhowe ${ }^{27}$ the court upheld as supported by consideration the payment of four pounds in discharge of a debt of five pounds, "for it is a benefit unto him to have it without suit or charge." 28

So if Pinnel's Case did not require that modifications be supported by consideration to be actionable in contract or assumpsit, what case did? Not a decision by the great Coke, and not a decision dating to the early seventeenth century; rather, it was Cumber $v$. Wane, ${ }^{29}$ a 1718 decision by the decidedly less eminent Sir John Pratt. ${ }^{30}$ This was a case sounding in indebitatus assumpsit in which the plaintiff sought $£ 15$ and the defendant pleaded that he gave the plaintiff a promissory note for $£ 5$ in satisfaction, which the plaintiff took accordingly. ${ }^{31}$ For a unanimous court, Chief Justice Pratt held that it was not sufficient that the plaintiff agreed to accept the defendant's satisfaction, but that "it must appear to the Court to be a reasonable satisfaction." 32 Then came the holding in the form of a rhetorical question: "If 5l. be (as is admitted) no satisfaction for $15 \mathrm{l}$. why is a simple contract to pay 5l. a satisfaction for another simple contract of three times the value?"33

It is odd to see a holding put in the form of a question, at least outside of the game show Jeopardy. But the question itself is faulty. Chief Justice Pratt seems to equate the action in indebitatus assumpsit with the action in debt when he states his major premise. This is not irrational; indebitatus assumpsit is close enough to debt that one might reasonably treat proof of satisfaction and proof of consideration alike. As Brian Simpson has pointed out, however, accord and satisfaction as a defense to assumpsit pertains only to unliquidat-

26. Bagge v. Slade [1616] 81 Eng. Rep. 137, 137; 3 Bulst. 162, 162.

27. Reynolds v. Pinhowe [1595] 78 Eng. Rep. 669; Cro. Eliz. 429.

28. Ames collects much more authority to this effect. See Ames, supra note 19, at 523-24.

29. Cumber v. Wane [1718] 93 Eng. Rep. 613; 1 Strange 426.

30. Referred to by the waspish Lord Campbell as "a dull lawyer, of decent character" and "not very eminent for his talents or public services"-though, in fairness, Holdsworth called Chief Justice Pratt "an able lawyer, and a strong, dignified, and impartial judge." 3 LORD CAMPBELL, THE LIVES OF THE CHIEF JUSTICES OF ENGLAND 67, 75 (1881); see generally 12 SiR WILLIAM HOLDSWORTH, A HISTORY OF ENGLISH LAW 433 (1938).

31. 93 Eng. Rep. at $613-14 ; 1$ Strange at 426.

32. 93 Eng. Rep. at $614 ; 1$ Strange at 427.

33. Id.; see also, e.g., Fitch v. Sutton [1804] 102 Eng. Rep. 1058, 1058; 5 East. 231, 232 (following Cumber $v$. Wane for an actual payment in satisfaction; stating that "the decision in Cumber $v$. Wane is directly supported by the authority of Pinnell's case . . which never appears to have been questioned"). Chief Justice Pratt's opinion in Cumber v. Wane did not actually cite to Pinnel's Case, though Pinnel's Case did arise in argument. 93 Eng. Rep. at 614; 1 Strange at 426. 
ed damages, not to liquidated debts. ${ }^{34}$ Chief Justice Pratt then asks how a simple contract for a lesser amount can serve as satisfaction of a simple contract for a greater amount. Asked at that level of generality, the answer seems obvious, at least if you grant his major premise. But that level of generality does not suffice. It assumes that an action for breach of contract and an action for nonpayment of a promissory note are equally valuable. That is not true now, and it was not true then. To take one instance, the statute of limitations for breach of the terms of the promissory note would start upon that breach; the statute of limitations for breach of the original contract would start upon that breach, by definition earlier. And note Chief Justice Pratt's statement that the satisfaction must not only be assented to but must also must be reasonable. The law of consideration was still somewhat unsettled in 1718, but ancient authority demands that courts not look for the adequacy of consideration but merely for its presence..$^{35}$

Ironically, the specific point in Cumber $v$. Wane-whether a note for a lesser amount could serve as satisfaction of a claim for a larger amount-was severely criticized, perhaps even overruled, by the middle of the nineteenth century, ${ }^{36}$ and the specific point about promissory notes was generally rejected in the United States. ${ }^{37}$ But, as Lord Blackburn observed, Cumber $v$. Wane was the first British decision after Pinnel's Case that asked whether payment of a lesser amount could be consideration for discharge of a larger liquidated debt. ${ }^{38}$ United States courts more often cite to Pinnel's Case, but they often pair it with Cumber $v$. Wane or cite to Cumber alone. ${ }^{39}$ Its substance has been buried, but it rules us still from its grave.

34. SIMPSON, supra note 18 , at 473.

35. See, e.g., Sir John Baker, Origins of the "Doctrine" of Consideration 1535-1585, in 3 SiR John BaKer, Collected PAPERS ON ENGlish Legal History 1176, 1183 (2013) ("The courts do not seem ever to have been troubled about economic disparity between consideration and promise....").

36. In Sibree v. Tripp, Chief Baron Pollock disagreed with Chief Justice Pratt's opinion and asked whether Cumber $v$. Wane had already been overruled. Sibree v. Tripp [1846] 153 Eng. Rep. 745, 749; 15 M. \& W. 22, 31. See also Goddard v. O’Brien [1882] 9 Q.B. 37, 39 (Grove, J.) ("[T] hat doctrine has been much qualified, and I am not sure that it has not been overruled.") (see also Huddleston, B., to the same effect). Foakes v. Beer was still more dismissive. See 9 App. Cas. (HL) 605, 628 (Lord FitzGerald, referring to "the infinitesimal remains of Cumber v. Wane").

37. See, e.g., Am. Seeding Mach. Co. v. Baker, 104 N.E. 524, 525 (Ind. Ct. App. 1914); Bartlett v. Woodworth-Mason Co., 41 A. 264, 265 (N.H. 1898); Draper v. Hitt, 43 Vt. 439, 441 (Vt. 1868). Accord and satisfaction by check is dealt with nowadays in U.C.C. $\S 3-311$.

38. Foakes v. Beer [1884] 9 App. Cas. (HL) 605, 619.

39. See, e.g., Chi., Minneapolis \& St. Paul Ry. Co. v. Clark, 178 U.S. 353, 364-65 (1900) (Cumber); Fichter v. Milk Wagon Drivers' Union, 46 N.E.2d 921, 924 (Ill. 1943) (both); Wm. Lindeke Land Co. v. Kalman, 252 N.W. 650, 655 (Minn. 1934) (Cumber); Jaffray v. Davis, 26 N.E. 351, 352-53 (N.Y. 1891) (both).

Nineteenth-century commentators usually associated the legal duty rule with Cumber v. Wane, directing toward it the obloquy that now descends upon Pinnel's Case. See Michael Lobban, Foakes v. Beer (1884), in LANDMARK CASES IN THE LAW OF CONTRACT 223, 228 
In short, Pinnel's Case has had horrible press for the last few centuries. Of itself, it was not important, and the ascent of assumpsit and then contract should have reduced it to triviality. The problem was how later courts used it, starting with the genuinely lousy decision in Cumber $v$. Wane. From this decision arose both the tangled exceptions to the legal duty rule and the many incomplete and uneven legislative interventions to mitigate its more ghastly effects. ${ }^{40}$ And, as others have observed, the legal duty rule "is, on the whole, that adjunct of the doctrine of consideration which has done most to give it a bad reputation." 41 Common as it is to deride consideration, there are some-not least among them this symposium's organizer-who have made cogent and serious arguments for its proper use. ${ }^{42}$ A doctrine as prominent and as revolting as the legal duty rule casts doubt on those who by inference would continue its existence.

The United Kingdom may soon break free of Cumber $v$. Wane and the like. The United Kingdom's Supreme Court has granted review in MWB Business Exchange v. Rock Advertising, ${ }^{43}$ in which the court of appeal essentially gutted the legal duty rule by adverting to "practical benefit." Should that court affirm, Foakes $v$. Beer and its predecessors will all but disappear in the United Kingdom; but in the United States, we are likely to retain it as our post-colonial damnosa horeditas. ${ }^{44}$

(Charles Mitchell \& Paul Mitchell eds., 2008). For one notable instance, see Cumber $v$. Wane, in I JOHN WILLIAM SMITH, A SELECTION OF LEADING CASES ON VARIOUS BRANCHES OF THE LAW 245, 253 (James Shaw Willes \& Sir Henry Singer Keating eds., 4th ed. 1856) ("[T]ts doctrine is founded upon vicious reasoning and false views of the office of a court of law....").

40. Most notably U.C.C. 2-209(1) (AM. LAW INST. \& UNIF. LAW COMM'N 2002) (eliminating the legal duty rule for sales of goods). On exceptions to the legal duty rule, see, e.g., Joseph Gold, The Present Status of the Rule in Pinnel's Case, 30 KY. L.J. 72, 73-74 (1941); Corneill A. Stephens, Abandoning the Pre-Existing Duty Rule: Eliminating the Unnecessary, 8 Hous. BuS. \& TAX L.J. 355 (2008); Kevin M. Teeven, Consensual Path to Abolition of Preexisting Duty Rule, 34 VAL. U. L. REV. 43 (1999).

41. Edwin W. Patterson, An Apology for Consideration, 58 CoLuM. L. REV. 929, 936 (1958).

42. See, e.g., Val D. Ricks, The Sophisticated Doctrine of Consideration, 9 GEO. MASON L. REV. 99 (2000); Val D. Ricks, In Defense of Mutuality of Obligation: Why "Both Should Be Bound, or Neither," 78 NEB. L. REV. 491 (1999); Val Ricks, Consideration and the Formation Defenses, 62 U. KAN. L. REV. 315 (2013); see also, e.g., Lon L. Fuller, Consideration and Form, 41 Colum. L. REV. 799 (1941); Harold C. Havighurst, Consideration, Ethics and Administration, 42 Colum. L. REV. 1 (1942); Karl N. Llewellyn, What Price Contract?-An Essay in Perspective, 40 YALE L.J. 704, 741-44 (1931); Patterson, supra note 41.

43. [2016] EWCA Civ. 553 [42].

44. While this anthology was in proof, the United Kingdom Supreme Court reversed the Court of Appeal, but on grounds that allowed it to avoid the consideration issue. Rock Advert. Ltd. v. MWB Bus. Exch. Centres Ltd., [2018] UKSC 24. The lead opinion in the case recognized that dealing with the consideration question was likely to involve a re-examination of the decision in Foakes $v$ Beer. It is probably ripe for re-examination. But if it is to be overruled or its effect substantially modified, it should be before an enlarged panel of the court and in a case where the decision would be more than obiter dictum. [2018] UKSC 24, at 18 (Sumption, L.J.). So Foakes lives on, though perhaps not for long. 
Mitchill v. Lath and Masterson v. Sine

\section{MARK P. GERGEN*}

Many contracts casebooks pair Mitchill v. Lath ${ }^{1}$ and Masterson v. Sine $^{2}$ to cover the parol evidence rule. ${ }^{3}$ There is much to be said for this pairing. These cases adopt the two leading, competing approaches to applying this rule. Mitchill $v$. Lath takes Samuel Williston's textualist approach; Masterson v. Sine takes Arthur Linton Corbin's contextualist approach. Forty years and a sea change in U.S. common law (from the traditional common law method to a progressive approach unfettered from precedent by legal realism) and in U.S. contract law (from classical contract law to modern contract law) separate the two cases. The courts that decided the cases were among the most influential state supreme courts in U.S. history: the New York Court of Appeals during the Judge Benjamin Cardozo era and the California Supreme Court during the Justice Roger Traynor era. As an added benefit, Masterson was decided the same year as Pacific Gas \& Electric Co. v. G.W. Thomas Drayage \& Rigging Co., ${ }^{4}$ which rejected a textualist approach to contract interpretation and adopted a contextualist approach.

So what is my argument that these cases should be counted among the worst contracts cases? Stated gently, each case places its chosen approach to the parol evidence rule in a bad light. Put in harsher terms, each court goes out of its way to apply its chosen approach to reach a result that was not required by the chosen approach and that is unjust in one case and wasteful in the other. I expect that in both cases the court proceeded this way to demonstrate its commitment to its chosen approach.

The principal disagreement between Williston and Corbin, regarding the parol evidence rule, was whether the court should consider the strength of the evidence of the alleged parol agreement in deciding

* Robert and Joann Burch D.P. Professor of Tax Law and Policy, Associate Dean for Faculty Development and Research, University of California Berkeley School of Law.

1. 160 N.E. 646 (1928).

2. 436 P.2d 561 (1968).

3. See Lon L. Fuller, Melvin A. Eisenberg, \& Mark P. Gergen, Basic CONTRACT LAW (9th ed. 2013); IAN AYERS \& RICHARD E. SPEIDEL, STUdIES IN CONTRACT LAW (7th ed. 2008): STEWART MACAUley ET AL., 2 CONTRACTS LAW IN ACTION (3d ed. 1993); ROBERT E. SCOTT \& JODY S. KRAUSS, CONTRACT LAW AND Theory (4th ed. 2017). John P. DAwson ET AL., ConTraCts: CASES AND CoMment (9th ed. 2008) has Mitchill in full (with photographs) and Masterson as a note case. Friedrich Kessler, Anthony T. Kronman \& Grant Gilmore, Contracts: Cases AND MATERIALS (3d ed. 1986) is the same without photographs. E.A. FARNSWORTH, ET AL., CONTRACTS: CASES AND MATERIALs (7th ed. 2008) has Masterson in full and Mitchill as a note case.

4. 442 P.2d 641 (Cal. 1968). 
whether the parol agreement can be proven as part of the contract. ${ }^{5}$ Williston argued that a court should not consider the strength of the evidence of the parol agreement in making this decision; Corbin argued that a court should consider the strength of such evidence. ${ }^{6}$

In Mitchill, the alleged parol agreement was a promise by the seller, who owned a country farm home, to the purchaser of such home, who purchased the home to use as a summer residence, to remove an unsightly icehouse that the seller had built and maintained on adjacent property that was owned by a third party. When the seller failed to remove the icehouse, the buyer brought an action in equity and sought an order to compel the seller to keep his promise. ${ }^{7}$ The trial court found that the seller had made the alleged promise and that the buyer relied on this promise when purchasing the home. The trial court ordered the seller to remove the icehouse. ${ }^{8}$

The New York Court of Appeals reversed in a five-two decision. Judge Andrews wrote the opinion for the majority. He adopted the Williston approach, under which the court makes "an inspection of the written contract, read in the light of surrounding circumstances," and holds the parol agreement to be discharged unless the court finds the parol agreement to "be one that parties would not ordinarily be expected to embody in the writing." Under this approach, an alleged parol agreement cannot be proven if the court thinks that in 51/100 cases people would include the agreement in the written contractconsidering only the character of the parol agreement, the text of the written contract, and the surrounding circumstances.

Judge Andrews acknowledged that the result was unfair to Catherine Mitchill, the purchaser, who had "spent considerable sums in improving the property for use as a summer residence." ${ }^{10} \mathrm{He}$ continued: "The defendants have not fulfilled their promise as to the icehouse, and do not intend to do so. We are not dealing, however, with their moral delinquencies." 11 Later he explained: "We have believed that the purpose behind the rule was a wise one, not easily to be abandoned. Notwithstanding injustice here and there, on the whole it works for good." ${ }^{2}$ The injustice to Mitchill in this case was outweighed by the benefits yielded by the rule in other cases and transactions.

5. John D. Calamari \& Joseph M. Perillo, A Plea for a Uniform Parol Evidence Rule and Principles of Contract Interpretation, 42 IND. L.J. 333 (1967).
6. Id. at 337-39.
7. Mitchill, 160 N.E. at 646 (synopsis).
8. Id. at 646,648 .
9. Id. at 647 .
10. Id. at 646 .
11. Id.
12. Id. at 647 . 
To be clear, my criticism of the case is directed neither at Judge Andrews' decision to adopt the Williston approach to applying the parol evidence rule nor at Judge Andrews' statement of the purpose of the rule. I will come back to these points. My criticism of Judge Andrews' decision involves the factual premise that people in the position of the parties would "ordinarily" put the agreement to move the icehouse in the contract for the purchase and sale of the house and farm. This is debatable. The standard contract for the purchase and sale of real property addresses the condition of the property that is being conveyed at length through warranties and conditions. Putting to the side cases in which property is sold as part of a larger development or project, a seller of property will undertake no obligations involving conditions on other land that is not being conveyed. Thus, there is no obvious or preordained place to put the agreement concerning the icehouse in the standard contract. The draftsman would not be expected to ask if there was such an agreement, and people in the position of the purchaser and seller in Mitchill might reasonably choose not to raise the issue with the draftsman and request that the agreement be included in the written contract. If the parties had raised the issue with the draftsman, then they would have had to work out the details, such as the time by when the icehouse had to be moved, to where the icehouse would be moved, and in what condition the seller was to leave the site of the icehouse.

Judge Andrews does not justify his factual premise. This is his entire argument on this key point:

[A]n inspection of this contract shows a full and complete agreement, setting forth in detail the obligations of each party. On reading it, one would conclude that the reciprocal obligations of the parties were fully detailed. Nor would his opinion alter if he knew the surrounding circumstances. The presence of the icehouse, even the knowledge that Mrs. Mitchill thought it objectionable, would not lead to the belief that a separate agreement existed with regard to it. ${ }^{13}$

The first two sentences would be unobjectionable if the promise concerned the condition of the real estate that was being conveyed. Looking at the contract, one could conclude that it "set forth in detail the obligations of each party" with respect to the real estate being conveyed. But, again, this agreement concerned the condition of other property. The fourth sentence is a brazen misstatement of the relevant question. Judge Andrews argued that one would not predict (or rather, think it more likely than not) that there was a side agreement to move the icehouse, if all one knew was that the icehouse existed and that Mitchill thought it objectionable. While this is correct, it is 
not the relevant question. The relevant question is whether one would predict (or think it more likely than not) that a side agreement to move the icehouse would be included in the contract-if a side agreement existed. These are very different questions. The question stated by Judge Andrews might be pertinent if Mitchill had argued there was a tacit agreement to move the icehouse.

This is why I say that Judge Andrews went out of his way to reach a result that is unfair. He could easily have applied the Williston approach and decided the case in Mitchill's favor. Your guess is as good as mine as to why Judge Andrews decided the case the way he did. I suspect he chose to sacrifice Mitchill on the altar of the parol evidence rule to send a message to lower courts and to contract draftsmen that the New York Court of Appeals took the parol evidence rule seriously.

In Masterson $v$. Sine, the alleged parol agreement was a restriction on an option retained by Dallas and Rebecca Masterson to repurchase a ranch they sold to Medora and Lu Sine for the consideration paid by the Sines "plus their depreciation value of any improvements" added by the Sines to the property. ${ }^{14}$ Medora Sine was Dallas's sister. Dallas had been declared bankrupt, and his trustee brought the action to obtain a declaratory judgment that he had the power to exercise the option. ${ }^{15}$ The Sine's principal argument was that the option was unenforceable because its terms were too uncertain. ${ }^{16}$ The Sine's also alleged that there was a parol agreement that the option was personal to Dallas and Rebecca to keep the property in the family. ${ }^{17}$ The trial court held that the parol evidence rule precluded admission of the evidence of the alleged parol agreement. ${ }^{18}$ Because it was a bench trial, we can infer that the trial court refused to consider the evidence, which was a proffer of testimony by Dallas.

The California Supreme Court reversed and directed the trial court to consider Dallas's testimony in a five-two decision. ${ }^{19}$ Justice Traynor wrote the opinion for the majority. He adopted the Corbin approach under which the trial court considers the strength of the evidence of the parol agreement in applying the rule. ${ }^{20}$ Under this

14. Id. at 562 .

15. Rebecca Masterson joined the bankruptcy trustee in the action. Masterson v. Sine, 436 P.2d 561, 562 (Cal. 1968). Apparently, this was to ensure that the Mastersons retained half of the value of the option if the trustee prevailed. Id.

16. The Supreme Court of California 1967-1968: Contracts, 56 CAL. L. REV. 1671, 1672 n.3 (1968).

17. Id. at 562 .

18. Id.

19. Id. at 567 .

20. Justice Traynor overturned a line of California cases that applied an approach to extrinsic evidence that was even more restrictive than the Williston approach, under which a court excludes the alleged parol agreement "if the written instrument on its face appears 
approach, the key issue is the credibility of Dallas's allegation that there was a parol agreement. My criticisms of Justice Traynor's opinion are that he never acknowledges this point, and he fails to address the strength of the evidence that contradicts the existence of an explicit agreement between the Mastersons and the Sines that the option was personal to the Mastersons.

Some of this evidence is circumstantial. It was in the interest of the Mastersons and the Sines to establish that the option was personal to the Mastersons because this would prevent the bankruptcy trustee from capturing half of the increase in the value of the ranch between 1958 and 1968 for the benefit of Dallas's creditors. Once Dallas's debts were discharged in bankruptcy, he and Rebecca could exercise the option and capture the entire increase in value for themselves. The only evidence offered of the alleged parol agreement was Dallas's testimony. The absence of corroborating testimony from Rebecca Masterson and the Sines regarding an explicit agreement is suspicious.

More direct evidence that contradicts the existence of an explicit agreement is found in Justice Burke's dissenting opinion: an admission by Dallas in his testimony that the "wording in the option was obtained" from "[his] attorney," who asked for and was given "little time to compose it" after Dallas told him of his discussion with the Sines. ${ }^{21}$ We can be fairly confident that, had Dallas informed his attorney that the option was intended to be personal to the Mastersons, his attorney would have added words to this effect in the option, such as "this option is nonassignable." 22 The likely inference is that Dallas never explicitly discussed the matter with Rebecca, the Sines, or his attorney.

Justice Traynor never acknowledges the relevance of these facts to the key issue in the case-which is Dallas's credibility in testifying that there was an explicit agreement that the option was personal to the Mastersons. ${ }^{23}$ This is why I say that Justice Traynor went out of

to state a complete agreement between the parties." See Note, Chief Justice Traynor and the Parol Evidence Rule, 22 STAN. L. REV. 547, 549, 551-52 (1970) (citing California cases, explaining how this approach differs from the Williston approach). The Supreme Court of California 1967-1968: Contracts, 56 CAL. L. REV. 1671, 1671-72 (1968), describes the overturned rule as "the 'face of the document' " rule.

21. Masterson, 436 P.2d at 572.

22. Justice Burke suggests this language in his dissent. Id.

23. One lacunae in Traynor's opinion concerns the weight that a court should give to the absence of a term in a writing in deciding the factual question of the existence of the alleged parol agreement. Justice Traynor compared the standard in Restatement (First) of Contracts, which "permits proof of a collateral agreement if it is such an agreement as might naturally be made as a separate agreement,' " to the standard in the comments of section 2-202 of the Uniform Commerical Code, which requires that evidence of the "alleged making" of the parol agreement should be kept from "the trier of fact" when "the additional terms are such that, if agreed upon, they would certainly have been included in 
his way to reach a result that is wasteful. He could easily have taken the Corbin approach and affirmed the decision of the trial court. The basis would be that Dallas Masterson failed to establish by the preponderance of the evidence that there was an explicit agreement between the Mastersons and Sines that the option was personal to the Mastersons. The factual issue of the existence of an alleged parol agreement that arguably is inconsistent with, or within the scope of, a written contract is a question for the court-not the jury-under the parol evidence rule. ${ }^{24}$ Your guess is as good as mine as to why Justice Traynor bothered to remand the case, rather than deciding the factual question himself. I suspect that he wanted to send a message to trial courts that they should address the factual question even when the evidence of the alleged parol agreement is weak.

I do not have strong views on the relative merits of the Williston and the Corbin approaches to applying the parol evidence rule. The Williston approach leads to an unjust result in cases where a party could establish the existence of a parol agreement, if given the opportunity to do so, but a court concludes, after examining the writing and considering the surrounding circumstances, that people ordinarily would include such an agreement in the writing. The Corbin approach leads to wasted effort in cases where a party attempts, but is unable, to persuade the court of the existence of the alleged agreement, when the Williston approach would have yielded the same result more quickly (and with greater certainty) because the alleged agreement contains a term that most people would include in the written contract. The two approaches may also have knock-on costs and benefits in their effects on contract execution and performance. For example, the Williston approach may have knock-on benefits with respect to contract performance by encouraging people to put their agreements in writing, which could reduce the incidence of disruptive misunderstandings or oversights. On the other hand, the Williston approach may enable people who are legally sophisticated to exploit people who are not.

The difference between the two approaches may not be that significant in practice-for what really matters under both approaches is the view of the court on the factual question whether people would

the document." Masterson, 436 P.2d at 564-65. Both standards speak to the strength of the negative inference to be drawn from the absence of a term in a writing. What is not explained is how this negative inference interacts with other evidence establishing or negating the existence of the parol agreement.

24. There should be no doubt on this point. See, e.g., William C Whitford, The Role of the Jury (and the Fact/Law Distinction) in the Interpretation of Written Contracts, 2001 WIS. L. REV. 931, 939 (2001) ("Even soft PER advocates normally will have a judge make the initial decision (sometimes called a 'provisional review') about the ambiguity or incompleteness of the writing, a result consistent with the general rule that interpretation of a writing is a legal issue."). 
and should be expected to include the alleged parol agreement in the written contract if the term were a part of the contract. My criticism of Mitchill and Masterson is that in each case the court took a tendentious position on this factual issue, yielding an unnecessarily unjust result in one case and an unnecessarily wasteful result in the other case. I suspect that in each case the court took a tendentious position on the factual issue to demonstrate its commitment to the preferred approach. This earns them a place on the list of the worst contracts cases. 


\section{Sherwood v. Walker: Replevin for Rose Redux}

\section{F. E. GUERRA-PUJOL ${ }^{*}$}

"Replevin for a cow": so begins the mistake case of Sherwood $v$. Walker. ${ }^{1}$ Two gentlemen farmers haggle over the price of a cow, and after agreeing on a sum certain ("five and a half cents per pound, less fifty pounds shrink" ${ }^{\text {") }}$, but before delivery, the seller discovers that the cow is pregnant and tries to back out of the deal, perhaps to resell her at a higher price. Despite such mundane facts, this bucolic bargain has generated extensive academic commentary. ${ }^{3}$ It has exemplified advanced methods of linguistic interpretation; ${ }^{4}$ it has roused academic economists to build toy mathematical models, ${ }^{5}$ it has even inspired verse. ${ }^{6}$ Moreover, this pastoral case has been called many things by many people: "an indisputably classic case and well-loved"; "the famous case of the sale of cow Rose $2 \mathrm{~d}$ of Aberlone"; "the classic case of the barren cow"; "the celebrated case of Rose of Aberlone"; 10 and "an ancient case revered by teachers of contract law," just to name a few favorable epithets. Hey, it has even been called "seminal." ${ }^{12}$ I, however, call it something else. I call it one of the worst contracts cases ever decided. Let us count the ways why.

* F. E. Guerra-Pujol teaches business law at the University of Central Florida. Thanks to Val Ricks, Dan O'Gorman, and Victoria Rosas for their comments on previous drafts of this paper.

1. 33 N.W. 919,919 (1887).

2. Id. at 920 .

3. For a small sample of this voluminous literature, see sources in PAUL Moreno, Sherwood v. Walker: Cows and Contracts, in THE VERdict of History: THE HisTORY OF Michigan JURISPRUDENCE THROUGH ITS SIGNIFICANT SUPREME COURT CAses 2, 5 (Significant Cases Comm. \& Angela Bergman eds., 2009). See also sources in infra notes 4-8.

4. See Alani Golanski, Nascent Modernity in the Case of Sherwood v. Walker: An Intertextual Proposition, 35 WILLAMETTE L. REV. 315, 315-16 (1999); Robert L. Birmingham, Essay, A Rose by Any Other Word: Mutual Mistake in Sherwood v. Walker, 21 U.C. DAVIS L. REV. 197 (1987).

5. See, e.g., Thomas J. Miceli, ECONOMiCs of THE LAW: TorTs, Contract, PROPERTY, Litigation 96-98 (1997); Eric Rasmusen \& Ian Ayres, Mutual and Unilateral Mistake in Contract Law, 22 J. of LEGAL STUD. 309, 313-17 (1993).

6. See Alan E. Garfield, Basic Assumption (A Poem Based on Sherwood v. Walker), 57 SMU L. REV. 137, 137 (2004); Brainerd Currie, Rose of Aberlone, 10 STUdenT LAW. J. 4, 4-8 (1965).

7. Birmingham, supra note 4 , at 208.

8. Richard A. POSNER, ECONOMIC ANALYSIS OF LAW 103 (6th ed. 2003).

9. White v. Mattox, 619 P.2d 9, 11 (Ariz. 1980).

10. Aluminum Co. of Am. v. Essex Grp., Inc., 499 F. Supp. 53, 65 (W.D. Pa. 1980).

11. H. Kook \& Co. v. Scheinman, Hochstin \& Trotta, Inc., 414 F.2d 93, 98 (2d Cir. 1969).

12. Florida v. Treasure Salvors, Inc., 621 F.2d 1340, 1349 (5th Cir. 1980), reh'g denied, 629 F.2d 1350 (5th Cir. 1980). 
For starters, the majority in Sherwood purports to raise a legal question when it frames the issue in the case in terms of mistake: were the parties mistaken about the "substance" of the transaction, or about an "accident" of it?"13 But this substance/accident distinction is a smokescreen, a juridical disguise designed to make it appear that the court is doing law when, in reality, it is finding facts. Whether Rose's ability to breed was the essence of the deal or merely an incidental aspect of it, this is a question of fact-not a question of law.

In fact, ${ }^{14}$ it turns out that the facts of this familiar case depend entirely on whom you ask. If you ask the buyer of the cow, he will tell you this case is, at worst, about the unilateral mistake of the seller, who erroneously thought his cow, Rose, to be "probably barren." ${ }^{15}$ By contrast, if you ask the seller, he will tell you a totally different tale. He will tell you how this case is about a mutual mistake-how both parties to the contract were surprised to learn (post-contract) that Rose was a breeder. Either way, a mistake is an erroneous belief that certain facts are true ${ }^{16}$ thus, the question of Rose's fertility is really a question of fact. It is axiomatic that, absent a clear error, AngloAmerican appellate courts do not decide questions of fact-only questions of law. ${ }^{17}$ Further, however blurry or hazy the distinction between facts and law might be in legal practice, ${ }^{18}$ a person's belief regarding some particular state of affairs - such as whether a cow named Rose of Aberlone is barren or not-is plainly a problem of fact, for this type of question requires a factual inquiry that can only be answered by reference to evidence or plausible inferences arising from the evidence. But wait; there's more.

In addition to invading the province of the jury, Sherwood gets the law wrong too, or at least it applies the doctrine of mistake incorrectly. Specifically, the court fails to appreciate the reciprocal nature of the mistake problem in contract law. To see this, imagine a reverse replevin case involving a cow by the name of Esor of Enolreba, instead of the immortal Rose of Aberlone. In this reverse replevin scenario, the parties both believe the cow to be fertile. (And, of course, instead of paying a mere $\$ 80$ for Esor, let's assume the buyer has shelled out $\$ 800$, since fertile cows are worth up to ten times more

13. Sherwood v. Walker, 33 N.W. 919, 923 (Mich. 1887).

14. Pun intended.

15. Sherwood, 33 N.W. at 920 .

16. 7 WeST's ENCYCLOPEDIA OF AMERICAN LAW 90-91 (Jeffrey Lehman \& Shirelle Phelps, ed., 2d ed. 2005).

17. Axiomatic as this principle might be, this is still a law review article, so see, for example, Concrete Pipe \& Prods. of Cal., Inc. v. Constr. Laborers Pension Tr., 508 U.S. 602, 621-626 (1993).

18. See, e.g., Ronald J. Allen \& Michael S. Pardo, The Myth of the Law-Fact Distinction, 97 NW. U. L. REV. 1769 (2003); Arthur W. Phelps, What Is a Question of Law?, 18 U. CIN. L. REV. 259 (1949). 
than barren cows.) Now, what if the buyer were mistaken about Esor's ability to breed? More to the point, what if Esor is infertile? According to the logic of Sherwood, the buyer should have the right to rescind the deal, return Esor to the seller, and get his money back!

But being wrong on the law and wrong on the facts is not enough to merit inclusion in this compilation of worst contracts cases ever. In addition to being wrongly decided on both counts (law and facts), Sherwood illustrates a fundamental legal fallacy, what I like to call the "binary world fallacy." Simply put, the court sees the world in binary terms - a common mistake, especially in law, where a defendant is either guilty or not guilty of breaching a legal duty or committing a crime. ${ }^{19}$ Given the binary logic of our legal system, it is understandable that the judges in the cow case would fall into this logical trap. After all, either Rose is pregnant or she is not. But seeing the world in binary terms does not help us solve the riddle of Rose the cow, for the central issue in this case is not whether Rose was pregnant or not; the main issue is the level of the parties' probabilistic beliefs regarding Rose's fertility. Stated formally, a cow's future ability to breed is not a binary proposition that must be either true or false, either 1 or 0 ; it is instead a mere conjecture, a hypothesis or a guess with a continuous probability distribution ranging from 0 to 1 .

To sum up, whether in poetry, prose, or precedent, Sherwood $v$. Walker has "taken on mythic proportions." 20 Yet it is still a bad case; one that deserves to be outed as a disgrace to our contracts canon. Although it purports to be a case about mutual mistake-in essence, about missteps in the making of contracts-in reality, Sherwood epitomizes another, more serious type of mistake: judicial blundering. Among other things, the court commits a probabilistic fallacy; it muddles the doctrine of mistake; it even gets the facts wrong. Cases like this one show us why close questions of fact are usually left to juries, not judges.

19. A contracts scholar as esteemed as Professor Charles Fried also falls into this particular trap-just in a different contract formation context-when he compares the process of contractual offer and acceptance to a set of two on/off switches. See CHARLES Fried, CONTRACT AS PROMISE: A THEORY OF CONTRACTUAL OBLIGATION 47-48 (1981). Although this switch metaphor works well most of the time, it is not always clear whether a party's conduct constitutes the making of an offer or the acceptance of an offer. Professor Fried himself recognizes this point when he asks, "[h]ow do we ever know what another person means, or that another person has understood what we mean?" Id. at 50. As such, my probabilistic analysis of law can apply even to the process of offer and acceptance.

20. Birmingham, supra note 4 , at 198. 


\section{Hadley v. Baxendale}

\section{KENNEY HEGLAND*}

"Of course zombies could have shown up and kept the mill going."

Whether Hadley is the best of cases or the worst of cases, it surely is the most popular of cases, the most cited (I am too old for footnotes) and I am told, but cannot personally attest, that the name "Hadley V. Baxendale" appears in the credits of Behind the Green Door-a wonderful gag, but my sense is that few stay for the credits. ${ }^{1}$

Hadley, a miller, contracted with Baxendale, a carrier, to have a broken shaft sent to the manufacturer for repairs. ${ }^{2}$ Due to some neglect, the shaft was not sent on time, and Hadley lost profits due to the delay; so he sued, and he won. ${ }^{3}$

On appeal, the court granted a new trial, and the jury was instructed not to consider lost profits because the circumstances did not show that the mill would lose profits if the shaft was not delivered on time. ${ }^{4}$ Who knows? Maybe Hadley had another shaft he could use; maybe another machine had broken and the mill couldn't run anyway; or maybe zombies arrived to save the day (my modest contribution to legal scholarship). Not to quibble, but it would be a very bad day to have two essential machines break down; and as to the backup shaft, was Hadley compulsive?

Of course, had Hadley told Baxendale that his was a unique case and that he had a pressing need for the shafts things might have turnd out differently. Alas, he only said that the "article to be carried was the broken shaft of a mill and that the plaintiffs were millers of the mill." ${ }^{5}$ Hold on there! In the first paragraph we are told that Hadley told Baxendale "the mill was stopped, that the shaft must be delivered immediately, and that a special entry, if necessary, must be made to hasten its delivery." 6 Now my short-term memory is not what it used to be, but come on, five short paragraphs? Maybe the

* Kenney Hegland is emeritus at Arizona. He has taught Contracts since the maiden voyage of Ship Peerless. The 7th edition of his Introduction to the Study and Practice of Law will be out this Fall. He has written a short, funny novel about us profs: Law School Chronicles.

1. Hadley v. Baxendale [1854] 156 Eng. Rep. 145, 145-46; 9 EX. 341, 341; see also Kprofs2013, Baxendale co-star dies in Hollywood, ConTRACTSPROFBLOG (Apr. 14, 2009), http://lawprofessors.typepad.com/contractsprof_blog/2009/04/baxendale-costardies-in-hollywood.html [https://perma.cc/649Y-4JWR].

2. Hadley, 156 Eng. Rep. at 146-47; 9 EX. at 341.

3. Id. at 151-52.

4. Id. at 151.

5. Id. at 150 .

6. Id. at 145 . 
clerk who transcribed the opinion was in his cups-gin was very popular. But let us just put this down as a fake statement of facts and move on.

Baxendale made a promise, he did not keep it, and that breach injured Hadley. Why should he, rather than Hadley, take the loss? The jury thought he should, but the court tells us that this would be the "greatest injustice." In tort law, you take the plaintiff as you find her-none of this "before you throw that apple let me tell you I have a very rare heart condition" nonsense. Why give the promisor a break? Between the two, it is more likely that the promisor would envision consequents of breach, as he is focusing on whether he can keep his word; the promisee is focusing on the price. It seems, however, that the greatest injustice does not turn on fault or who can better envision the harm, but rather on the harm that would flow if the jury did not buy into the notion of a cheap contract. But that is another article, and justice is beyond my scope.

"[I]f the jury [is] left without any definite rule to guide [it], it will . . . manifestly lead to the greatest injustice." ${ }^{\text {Put }}$ aside the notion that jurors might have a better idea of justice than do judges and focus instead on the notion "we cannot trust jurors." A core notion in the law is that is we cannot trust anyone to do the right thing. Jurors are roped in by the instructions (which they must follow), by parties by their carefully drafted contracts (which they often ignore), and by judges by, alas, Hadley.

Of course, Hadley did not start the fire. But are we sure that without instructions jurors would inflict the greatest injustice? Without precedent would judges be all over the lot? Why not at least think the unthinkable: junk it all and simply instruct folks to do the right thing. Do you do the right thing without first reciting rules to follow? Without Hadley, would the wild rumpus begin? 
In Re Marriage of Witten: Subordinating Contract to "Public Policy"

\section{NANCY S. KIM*}

In re Marriage of Witten ${ }^{1}$ is a case about a divorcing couple fighting over the fate of frozen embryos. ${ }^{2}$ It is a sad case - divorce cases usually are. It is also a good example of a bad contracts case.

Tamera and Trip Witten were a married couple who hoped to start a family. Eventually, they turned to in vitro fertilization (IVF). After seven-and-a-half years of marriage and several unsuccessful IVF attempts, Trip filed for divorce. At issue was whether Tamera Witten could use one of the seventeen frozen embryos which were in storage at the University of Nebraska Medical Center (UNMC). Tamera testified that if she were able to have a child using one of the embryos, she would give Trip the option of exercising or terminating his parental rights. ${ }^{3}$ In other words, she was not asking him to be a co-parent or to be involved in supporting or raising the child; she was merely opposed to destroying or donating the embryos. Trip, however, did not oppose donating the embryos to another couple- he just did not want Tamera to use them. ${ }^{4}$

Before starting the IVF process, the Wittens had signed documents prepared by the UNMC, including the "Embryo Storage Agreement," which contained a provision that the embryos would be released "only with the signed approval of both Client Depositors." UNMC's obligation to store the embryos would terminate if the parties died, if they authorized the destruction of the embryos, if they failed to pay the annual storage fee, or if ten years passed after the date of the agreement. ${ }^{6}$

On appeal, Tamera argued that the storage agreement was silent with respect to what would happen to the embryos in the event that the parties divorced. In other words, she was making an "omitted terms" argument. But rather than arguing for an interpretation based upon the intent of the parties, she argued that an Iowa statute should apply to award her "custody" of the embryos. That Iowa stat-

* ProFlowers Distinguished Professor of Internet Studies and Professor of Law, California Western School of Law; Visiting Professor, Rady School of Management, University of California, San Diego.

1. 672 N.W.2d 768 (Iowa 2003).

2. As the court noted, the "embryo[s]" were likely "pre-zygotes" or "preembryos." Id. at 772 n.1. However, the court used the term "embryo" because that was the term used in the Witten's contract with UNMC. Id. Because the court adopted the term "embryo," I do so for the purposes of this essay.
3. Id. at 772 .
4. Id. at $772-73$
5. Id. at 772 .
6. Id. 
ute set forth various standards which courts should use to determine the custody of children in divorce proceedings. ${ }^{7}$

As the court noted, Tamera was essentially arguing that "the embryos are children and their best interest demands placement with her." "Trip, on the other hand, argued that "the frozen embryos are not children and should not be considered as such" under Iowa law. ${ }^{9}$ Tamera's argument thus boxed the court into a politically uncomfortable corner. In order for the court to rule in her favor, the court would have had to find, at least by implication, that embryos were equivalent to children. Because Tamera's argument was based on policy rather than contract, the court was forced to base its interpretation on legislative intent rather than on the reasonable expectations of the parties.

The court considered the legislative purpose underlying the relevant statute and concluded that "the legislature did not intend to include fertilized eggs or frozen embryos within the scope" of the relevant law. ${ }^{10}$ Tamera also made the argument that the contract violated public policy because it allowed a participant in an IVF program to renege on an agreement to become a parent. ${ }^{11}$ But rather than argue on the basis of detrimental reliance, Tamera again strayed into volatile territory by trying to convince the court that it was against public policy to enforce an agreement which allowed "a donor to abandon [IVF] attempts when viable embryos remain." 12 The court pushed back against this argument, again making a distinction between "children who have been born" and "fertilized eggs that have not even resulted in a pregnancy." 13 The court's decision on these two points is wise in light of how Tamera framed the issue. The court simply could not side with her without also equating embryos with children-something which would likely have unfortunate implications given the political heat which surrounds the right to abortion. The court noted that the power to invalidate a contract on public policy grounds must be exercised "cautiously and only in cases free from doubt."14

But then the court turned its back on contract law in favor of public policy in the area of reproduction: "We think, however, that it would be against the public policy of this state to enforce a prior agreement between the parties in this highly personal area of repro-

\footnotetext{
7. Id. at $774-74$.

8. Id. at 774 .

9. Id.

10. Id. at 776 .

11. Id. at 780 .

12. Id.

13. Id.

14. Id.
} 
ductive choice when one of the parties has changed his or her mind concerning the disposition or use of the embryos." 15

The court noted that family and reproductive decisions are "emotional in nature and subject to a later change of heart"16 and thus concluded that judicial enforcement of contracts between couples on "future family and reproductive choices would be against . . . public policy." ${ }^{\prime 17}$ It then noted that agreements between donors and fertility clinics, however, were enforceable. ${ }^{18}$ The court jettisoned the ability of couples to enter into contracts involving matters of family planning in favor of a "contemporaneous mutual consent" model which allows either party to change his or her mind. This no-contract approach ignores one of the primary purposes of contracts - to assist in planning for the future and to encourage acts of reliance that are a necessary part of such a planning process. Furthermore, the contemporaneous mutual consent model completely ignores the inherently unequal nature of the IVF process. It is the woman who bears the painful, physical burdens which the process involves. Thus, it is the woman who will undertake acts of detrimental reliance upon a promise to participate in the IVF process. The woman is also the one who feels more keenly the effects of time on fertility. Often, as it was in the case of Tamera and Trip, it is also the woman who would be financially unable to undergo another round of IVF procedures after a divorce. ${ }^{19}$ The contemporaneous mutual consent model presumes an equality which just does not exist when it comes to the IVF process.

The court held that "there can be no use or disposition of the Wittens' embryos unless Trip and Tamera reach an agreement." ${ }^{20}$ It then added, either cluelessly or mean-spiritedly, that the party who opposes destruction of the embryos is responsible for storage fees. ${ }^{21}$ The court's decision thus put Tamera in the humiliating position of trying to wheedle consent from Trip while continuing to make payments to keep the eggs in storage.

On the first day of class, I tell my contracts students about the bargain principle. I tell them that, with a few caveats, courts will not review the adequacy of consideration or the fairness of contractual

15. Id. at 781 .

16. Id. at 782 .

17. Id.

18. Id.

19. Trip's income was "substantially larger" than Tamera's. Id. at 784. According to documents submitted to the court, Tamera earned $\$ 3,087, \$ 3069$, $\$ 0$ and $\$ 15,623.27$ during the years 1999, 2000, and 2001, respectively. See Respondent-Appellant's/Cross-Appellee's Reply Brief at 2, In re Witten, 672 N.W. 2d 768 (2003) (No. 03-0551), 2003 WL 24314608.

20. Witten, 672 N.W. 2 d at 783.

21. Id. at 784-85. The court also overturned the trial court's order that Trip pay Tamera cash for her share of his retirement account. Id. at 785. 
terms. Contract law is about autonomy, individualism, and freedom. Contract law is tough, I say; it expects you to say what you mean and mean what you say.

But students soon learn that the law is full of qualifiers and exceptions. Contract law, it turns out, is not so tough after all. The most obvious examples of contract law's compassionate side are unconscionability, duress, and the changed circumstances doctrines. But flexibility is an integral part of every aspect of contract law. Consideration, mistakes, good faith and fair dealing, interpretation standards- every contract doctrine has nestled within it some expectation of fairness - some ceding to context and social norms of decency. To calm the skittish who fear the slippery slope, "fairness" and "justice" often masquerade as "reasonableness" and "good faith." Nevertheless, wise judges understand that there are some bargains which should not be upheld, and conversely, that there are some promises which must be kept. The equitable doctrines also play their part. Promissory estoppel, quasi contract, restitution, moral obligation-these contractual kin accomplish their goals to the extent necessary to avoid injustice. ${ }^{22}$

In re Witten relegates contracts to second-class status. Much of the blame lies with Tamera's legal counsel. Tamera's arguments about "custody" of fertilized eggs and a "fundamental right" to pregnancy ring alarm bells for anyone concerned about abortion rights and reproductive freedom. It is not difficult to imagine that the court made its ruling with a worried eye to those who might use the case for political ends. But by expressly dismissing the power of contracts in the realm of intimate relations and ignoring the flexibility of contract doctrines to fulfill reasonable expectations and prevent injustice, the Witten court went too far and diminished reproductive freedom. Couples make promises to each other all the time. Sometimes, those promises result in acts of heartbreaking reliance. Contract law and its equitable kin allow judicial enforcement of promises in such cases. In re Witten should have been one of those cases.

22. See, e.g., RESTATEMENT (SECOND) OF CONTRACTS $\$ 86$ (AM. LAW INST. 1981) (stating that a promise made in recognition of a benefit conferred bindes the promisee "to the extent necessary to prevent injustice"); Id. $§ 89$ (modification without consideration binding "to the extent that justice requires enforcement"); Id. $\$ 90$ (promise which induces reasonable detrimental reliance is binding "if injustice can be avoided only by enforcement of the promise"). 


\title{
Mangled Metaphors: ProCD, Inc. v. Zeidenberg*
}

\author{
Michael P. MALLOY ${ }^{\dagger}$
}

What makes a case the worst of its kind? It may be that a decision offends fundamental principles and sensibilities. ${ }^{1}$ Or it may be that the decision misunderstands or misapplies applicable law in some significant way. ${ }^{2}$ Finally, however, it may be that the outcome is arguably correct, but the reasoning, tone, and approach of the decision is extremely clumsy and distracting. ProCD, Inc. v. Zeidenberg ${ }^{3}$ falls into this third category. It is a decision grounded in very formalistic analysis, and it is out of touch with the practical reality of the tech market. It has spawned fuzzy concepts concerning contracts in a digital age.

\section{Introduction}

ProCD opens with what appears to be a very straightforward question, followed by a deceptively straightforward answer:

Must buyers of computer software obey the terms of shrinkwrap ${ }^{[4]}$ licenses? The district court held not, for two reasons: first, they are

* Copyright (C) 2017 Michael P. Malloy. A fuller version of this paper was presented at the Twelfth Annual International Conference on Contracts (KCON XII) on 25 February 2017. This paper was inspired by discussions that I had with Claude D. Rohwer and Anthony M. Skrocki, my colleagues and coauthors on CONTRACTS IN A NUTSHELL (8th ed. 2016), for which I am forever grateful. I also wish to thank former Dean Francis J. Mootz III and former Associate Dean Raquel Aldana of the University of the Pacific McGeorge School of Law for their generous support and encouragement of my work on this project.

$\dagger$ Distinguished Professor \& Scholar, University of the Pacific McGeorge School of Law. J.D., University of Pennsylvania (1976); Ph.D., Georgetown University (1983).

1. See, e.g., Plessy v. Ferguson, 163 U.S. 537 (1896) (establishing legal rationale for separation of people based upon race), overruled by Brown v. Board of Educ., 347 U.S. 483 (1954).

2. See, e.g., Fertico Belg. S.A. v. Phosphate Chems. Exp. Ass'n, 100 A.D.2d 165 (N.Y. App. Div. 1984) (in letter of credit case governed by Uniform Customs and Practices, repeatedly citing to UCC Article 5 as authority throughout opinion).

3. 86 F.3d 1447 (7th Cir. 1996).

4. A shrink wrap contract term or license involves provisions inside the package containing the software, where the package is heat-sealed with plastic or cellophane wrap:

Once the software package is opened the purchaser is presented with the license, and is supposed to then read and understand it. Once read the purchaser then has the option of accepting the conditions within the license by proceeding to use or install the software, or the purchaser may choose to reject the license and return the un-used software for a refund. The purported license attempts to limit the rights of possessors of the software by prohibiting copying and distribution of the software, and retains ownership of the software with the copyright holder.

Novell, Inc. v. Network Trade Ctr, Inc., 25 F. Supp. 2d 1218, 1230 n.16 (D. Utah 1997), vacated in part, 187 F.R.D. 657 (D. Utah 1999). There is a continuing grammatical dispute about the proper usage of the expression "shrink wrap." ProCD uses "shrinkwrap," with no space or hyphen. See, e.g., ProCD, 86 F.3d at 1448 ("the terms of shrinkwrap licenses"). Most, if not all, 
not contracts because the licenses are inside the box rather than printed on the outside; second, federal law forbids enforcement even if the licenses are contracts. ${ }^{5}$

The Court of Appeals for the Seventh Circuit misstated the holdings of the court below. ${ }^{6}$ In any event, it is easy to lose sight of the one principle that ProCD concedes right at the beginning of the opinion: "Shrinkwrap licenses are enforceable unless their terms are objectionable on grounds applicable to contracts in general (for example, if they violate a rule of positive law, or if they are unconscionable)." 7 It should follow then that the fact that terms are embedded in shrink wrap should not in itself mean that the general principles of contract law do not apply to the contract in question.

\section{Case Summary}

On three occasions, Mr. Zeidenberg bought ProCD's SelectPhone ${ }^{\mathrm{TM}}$ database and search engine, which was distributed on CD-ROM discs in a sealed package that included a license agreement, ${ }^{8}$ thus prohibiting purchasers from distributing the contents or making them available through a network. ${ }^{9}$ The only indication on the exterior of the package that a license lurked within was a small printed notice at the bottom of the package. ${ }^{10} \mathrm{Mr}$. Zeidenberg uploaded the SelectPhone $^{\mathrm{TM}}$ database to an Internet site, and ProCD sued him for breach of the license agreement. ${ }^{11}$ In response, Mr. Zeidenberg argued that the terms of that agreement were not included in whatever contract he and ProCD had entered into. ${ }^{12}$

of the published legal scholarship follows this usage. See, e.g., Mark A. Lemley, Terms of Use, 91 MINN. L. REV. 459, 459-60 (2006) (article by a professor, who was an attorney for one amicus in ProCD, stating, "[a] majority of courts in the last ten years have enforced shrinkwrap licenses"). Most online sources follow the usage of spacing "shrink" and "wrap" as separate words. See, e.g., Shrink wrap, WIKIPEDIA, https://en.wikipedia.org/wiki/Shrink_wrap [https://perma.cc/A55R-QTKA] ("Software on carriers such as CDs or DVDs are often sold in boxes that are packaged in shrink wrap. The licenses of such software are typically put inside the boxes, making it impossible to read them before purchasing.").

5. ProCD, 86 F.3d at 1448-49.

6. The district court held that a contract had already been formed without the unknown licenses. See ProCD, Inc. v. Zeidenberg, 908 F. Supp. 640, 652 (W.D. Wis. 1996) ("The purchase of the product was sufficient to show agreement between the parties.")). The court also held that federal copyright law preempted terms in the license; see id. at 659 ("Plaintiff cannot use a standard form contract to make an end run around copyright law. Its contract claim is preempted by [Copyright Act] $\S 301 . ”)$.

7. ProCD, 86 F.3d at 1449 (emphasis added).

8. The terms of this license were set forth in an enclosed user guide. Id. at 1450. The terms also appeared on-screen when a user (including, presumably, Mr. Zeidenberg) used the disks. Id.
9. Id.
10. Id. See also ProCD, 908 F. Supp. at 654 .
11. ProCD, 86 F.3d at 1450 .
12. Id. 
Treating the parties' agreement as a sale of goods ${ }^{13}$ and invoking section 2-206, 2-207, and 2-209 of the UCC, the Western District of Wisconsin ruled for $\mathrm{Mr}$. Zeidenberg on this issue. ${ }^{14}$ In an opinion by Judge Easterbrook, the Seventh Circuit reversed, holding that the parties' agreement included the shrink-wrapped terms of the user license. ${ }^{15}$ Like the lower court, the Seventh Circuit assumed that UCC Article 2 governed the parties' agreement, ${ }^{16}$ but it saw no "battle of the forms" in the transaction to which section 2-207 of the UCC might be applied. ${ }^{17}$ The court therefore focused on section 2-204 of the UCC, which loosens up common law standards for contract formation and recognizes "[a] contract for sale of goods . . . made in any manner sufficient to show agreement." 18 The result is that an obscure notice on a purchased package incorporated the unrevealed, shrinkwrapped terms into the contract at the point of sale.

\section{Misleading Metaphors}

What one scholar says generally about Internet-access cases applies with particular force to the argumentation in ProCD: "The result is an uneven blend of doctrine and metaphor."19 The case runs rapidly through a series of analogies and metaphors to buttress its position. Buying the software package is like "the purchase of insurance," where terms show up afterwards in the policy. ${ }^{20}$ That is misleading. The policy is the objective of that purchase; the shrink-wrapped terms are not. The case then jumps to an analogy to airline tickets, ${ }^{21}$ but passengers

13. In so doing, the district court relied mainly on Mark A. Lemley, Intellectual Property and Shrinkwrap Licenses, 68 S. CAL. L. REV. 1239, 1241 (1995) without exploring independently whether the agreement should in fact be characterized as a sale of goods or as a user license. ProCD, Inc., 908 F. Supp. at 650-51 (W.D. Wis. 1996).

14. ProCD, Inc., 908 F. Supp. at 651-55. The district court also held that section 301(a) of the Copyright Act (17 U.S.C. $\S 301(a)$ ) preempted the enforcement of the terms of the shrink-wrapped agreement. $I d$. at 656-59.

15. ProCD, 86 F.3d at 1449-50. The Seventh Circuit also rejected the preemption argument under the Copyright Act. Id. at 1453-55 (holding that a user license constituted rights created by contract not "equivalent to any of the exclusive rights within the general scope of copyright").

16. See id. at 1450 ("[W]e treat the licenses as ordinary contracts accompanying the sale of products, and therefore as governed by the common law of contracts and the Uniform Commercial Code.").

17. See id. at 1452 ("Our case has only one form; UCC $\S 2-207$ is irrelevant.").

18. U.C.C. § 2-204(1) (AM. LaW Inst. \& UnIF. LaW. Comm’n 1977). See ProCD, 86 F.3d at 1452 (applying section 2-204 of the UCC and found that "ProCD proposed a contract that a buyer would accept by using the software after having an opportunity to read the license at leisure. This Zeidenberg did.").

19. Michael J. Madison, Rights of Access and the Shape of the Internet, 44 B.C. L. REV. 433, 434 (2003).

20. ProCD, 86 F.3d at 1451.

21. Id. 
are alerted up front to the significance of ticket terms, which was not the case here.

The case then analogizes to consumer goods ${ }^{22}$ - a bad choice since the abuses there are well-known and now subject to regulation. ${ }^{23}$ At another point, ProCD suggests that shrink-wrap contracting is "reinforce[d]" by section 2-606 of the UCC, which allows for inspection before "acceptance of goods." ${ }^{4}$ This is specious: acceptance of goods pursuant to an existing agreement, the subject of that section, is nothing like acceptance of an offer, the issue in ProCD. The problem is not whether a contract can be "money now, terms later," ${ }^{25}$ but whether that was what actually occurred in the case. ${ }^{26}$

\section{Conclusion}

As modern contracting has moved from telex ${ }^{27}$ to facsimile, ${ }^{28}$ to email,,$^{29}$ to online apps, ${ }^{30}$ and soon to as yet unimagined methods, ${ }^{31}$ new technologies almost always creates new challenges for contract law. In such moments, there is a need for new analysis and adaptable principles for contracting, but without abandoning the objectives underlying contract law. ProCD and its progeny effectively give the offeror the power to dictate special terms as to acceptance. This leads to cynicism about contracts without assent, which weakens the legitimacy of contract law. ${ }^{32}$

22. Id.

23. See, e.g., Michael P. Malloy, PRinciples of Bank Regulation $\$ 10.10$ (3d ed. 2011) (examining the current scope and applicability of consumer protection regulation).

24. Id. at 1452 .

25. Id.

26. Cf. Specht v. Netscape Comm. Corp., 306 F.3d 17 (2d Cir. 2002) (taking a more realistic approach to digital contracting).

27. See Apex Oil Co. v. Vanguard Oil \& Serv. Co., 760 F.2d 417 (2d Cir.1985) (holding that a telex constituted a "writing" satisfying the requirement of of a writing confirming the existence of a contract under section 2-201(2) of the UCC).

28. See, e.g., U.C.C. $\S 5-102$, cmt. 2 (discussing when a facsimile transmission would constitute a "document" for purposes of a letter of credit transaction).

29. Cf. Hessenthaler v. Farzin, 564 A.2d 990, 992 n.3 (Pa. Super. Ct. 1989) (dicta, alluding favorably to e-mails, telexes, and faxes as a "signed writing" within real estate statute of frauds).

30. See, e.g., Hancock v. Am. Tel. and Tel. Co., 701 F.3d 1248, 1256 (10th Cir. 2012) (observing that "[c]lickwrap agreements are increasingly common and have routinely been upheld" ").

31. See generally 15 U.S.C. § 7001(a) (providing that an electronic "signature, contract, or other record" is not invalid "solely because it is in electronic form"; such a contract cannot be invalid "solely because an electronic signature or electronic record was used in its formation").

32. See, e.g., i.Lan Sys., Inc. v. Netscout Serv. Level Corp., 183 F. Supp. 2d 328, 329 (D. Mass. 2002) ("You probably do not agree in your heart of hearts, but you click anyway."). 


\section{Justice Traynor and the Summer of Love: Misunderstanding the Parole Evidence Rule in Pacific Gas}

\section{NATHAN B. OMAN}

During 1968, the Summer of Love, the California Supreme Court decided Pacific Gas \& Electric Co. v. G. W. Thomas Drayage \& Riggingand Co. ${ }^{1}$ Pacific Gas \& Electric (PG\&E), a massive utility, hired Drayage to remove and replace the cover of one of the huge steam turbines in its power plants. ${ }^{2}$ The terms of the agreement stated that Drayage would "indemnify" PG\&E "against all loss, damage, expense and liability resulting from ... . injury to property, arising out of or in any way connected with the performance of this contract." 3 During the repair, the delicate rotor of the turbine was exposed, and the heavy cover fell and damaged it. ${ }^{4}$ PG\&E suffered $\$ 25,144.51$ in damages. ${ }^{5}$ It sued Drayage, arguing that the terms of the written agreement required Drayage to pay for the loss. ${ }^{6}$ At trial, Drayage argued that the terms did not require payment and insisted that they had only agreed to indemnify PG\&E for "loss, damage, expense and liability" caused to third parties for which PG\&E became liable. ${ }^{7}$ In support, Drayage "offered to prove by admissions of plaintiff's agents, by defendant's conduct under similar contracts entered into with plaintiff, and by other proof that in the indemnity clause the parties meant to cover injury to property of third parties only and not to plaintiff's property." evidence problem of the extent to which a court is permitted to admit testimony of extrinsic evidence that is offered to construe the meaning of a written document.

Throughout 1968, Chief Justice Roger Traynor had waged war on the traditional parol evidence rule. In Masterson $v$. Sine ${ }^{9}$ his majority opinion held that, on the issue of final and complete integration, all relevant evidence should be considered.$^{10}$ Masterson reversed the long-standing common-law rule that a document that appeared com-

* Rita Ann Rollins Professor of Law, William \& Mary Law School.

1. 442 P.2d 641 (Cal. 1968).

2. Id. at 643 .

3. Id.

4. Id.

5. Id.

6. Id.

7. Id.

8. Id.

9. 436 P.2d 561 (Cal. 1968).

10. See id. at 564 ("Evidence of oral collateral agreements should be excluded only when the fact finder is likely to be misled."). 
plete on its face should be deemed to be fully integrated. ${ }^{11}$ Yet Masterson's rhetoric was relatively restrained. In Pacific Gas, Chief Justice Traynor gave vent to his academic spleen against the parol evidence rule.

Unfortunately, he fundamentally misunderstood what is at issue in the parol evidence rule, muddied the analysis, and created a doctrinal structure that later California courts largely abandoned. Chief Justice Traynor mistakenly assumed that the traditional four corners rule was based on a theory of language:

When a court interprets a contract on this basis, it determines the meaning of the instruments in accordance with the . . . "[E]xtrinsic evidence of the judge's own linguistic education and experience." The exclusion of testimony that might contradict the linguistic background of the judge reflects a judicial belief in the possibility of perfect verbal expression. This belief is a remnant of a primitive faith in the inherent potency and inherent meaning of words. ${ }^{12}$

Not content to cite Arthur Linton Corbin and John Henry Wigmore, for this benighted view of language Chief Justice Traynor proposed examples ranging from folk remedies to god "Thoth, the Scribe of Truth" in what remains the most bizarre footnote in American contracts jurisprudence. ${ }^{13}$

On Chief Justice Traynor's view, the four corners rule in the Restatement of Contracts was an instantiation of a naïve belief in the talismanic force of words, a bit of mystical nonsense like efforts to cure livestock with magic brew containing pages clipped from the Bible. Nor was this dark humor; ${ }^{14}$ Chief Justice Traynor tilts at this windmill in earnest: "If words had absolute and constant referents, it might be possible to discover contractual inten-

11. See e.g., Thompson v. Libbey, 26 N.W. 1 (Minn. 1885) (holding that the question of whether a document was fully integrated should be determined from the four corners of the document).

12. Pac. Gas \& Elec. Co., 442 P.2d at 643-44.

13. Traynor theorized,

The elaborate system of taboo and verbal prohibitions in primitive groups; the ancient Egyptian myth of Khern, the apotheosis of the word, and of Thoth, the Scribe of Truth, the Giver of Words and Script, the Master of Incantations; the avoidance of the name of God in Brahmanism, Judaism and Islam; totemistic and protective names in mediaeval Turkish and Finno-Ugrian languages; the misplaced verbal scruples of the 'Précieuses'; the Swedish peasant custom of curing sick cattle smitten by witcheraft, by making them swallow a page torn out of the psalter and put in dough.

Id. at $643 \mathrm{n} .2$.

14. The opinion speaks derogatorily of "magic words," even though the parole evidence rule has never been construed to require a particular verbal formulation in a contract. $I d$. at 644. See also BARRY NiCHOLAS, AN INTRODUCTION TO ROMAN LAW 143-195 (1962) (discussing the stipulation, which is a contractual form that required that contracting parties to say certain "magic words" in order to create liability). 
tion in the words themselves .... Words, however, do not have absolute and constant referents." 15

Accordingly, Chief Justcie Traynor held that the trial court erred in excluding the proffered evidence. ${ }^{16}$ Any time language is "reasonably susceptible" to the interpretation argued for by the party wishing to introduce extrinsic evidence, the court said that there must be "at least a preliminary consideration of all credible evidence offered to prove the intention of the parties." 17

Pacific Gas is a tour de force of bad judging. First, as Chief Justice Traynor himself admits, neither linguistic theory nor the "reasonably susceptible" doctrinal framework was necessary to decide the case. ${ }^{18}$ "Indemnify" was ambiguous, the court held, even without extrinsic evidence. ${ }^{19}$ Even under the four corners rule the trial court improperly excluded extrinsic evidence. ${ }^{20}$

Far more damning, however, was Chief Justice Traynor's misunderstanding of the parol evidence rule. The rule does not rest on a particular theory of language. In his 1988 opinion in Trident Center $v$. Connecticut General Life Insurance Co., ${ }^{21}$ Judge Kozinski savaged Chief Justice Traynor's aria on the philosophy of language, arguing that it leads to a rule-of-law-underming nihilism. ${ }^{22}$ For contract law, however, the problem is less metaphysical. ${ }^{23}$

15. Pac. Gas \& Elec. Co., 442 P.2d at 644.

16. Id. at 646 .

17. Id. at 646 .

18. Id. at $646 \mathrm{n} .9$.

19. Id. ("The trial court's recognition of the language as typical of a third-party indemnity clause and the double sense in which the word 'indemnify' is used in statutes and defined in dictionaries demonstrates the existence of an ambiguity.").

20. While not technically dicta, Chief Justice Traynor's opinion reaches beyond the case's facts to create new law even though such new law had no impact on the resolution of the dispute. On this point, contrast Pacific Gas with Masterson v. Sine, 436 P.2d 561 (Cal. 1958). In Masterson, the court was faced with a formal deed that had been professionally prepared. Id. at 568 ("The contract of sale and purchase of the ranch property here involved was carried out through a title company."). Under the traditional common law approach, there was no reason to suppose that such a formal document was not fully integrated. See also Thompson v. Libbey, 26 N.W. 1 (Minn. 1885). The admission of extrinsic evidence in the case was only possible because the California Supreme Court changed the law. (Masterson's indescretions are outlined in Gergen on Masterson p. 983.) In contrast, Chief Justice Traynor's new framework in Pacific Gas was wholly gratuitous.

21. 847 F.2d 564 (9th Cir. 1988).

22. Id. at 569 (Pacific Gas "chips away at the foundation of our legal system. By giving credence to the idea that words are inadequate to express concepts, Pacific Gas undermines the basic principle that language provides a meaningful constraint on public and private conduct. If we are unwilling to say that parties, dealing face to face, can come up with language that binds them, how can we send anyone to jail for violating statutes consisting of mere words lacking 'absolute and constant referents?" ).

23. See, e.g., Susan J. Martin-Davidson, Yes, Judge Kozinksi, There Is a Parol Evidence Rule in California-The Lessons of a Pyrrhic Victory, 25 SW. U. L. REV. 1 (1995) (criticizing Judge Kozinski's view as overblown). 
Chief Justice Traynor's theorizing simply misses the point of the parole evidence rule. The function of the parol evidence rule is to limit the range of evidence available in construing the terms the contract. ${ }^{24}$ Expanding or contracting the scope of the evidence considered by the court always involves a trade-off. Increasing the range of evidence can increase the probability that the court's decision will track the subjective agreement of the parties. By constricting the available evidence, the parol evidence rule thus creates the risk of errors. In one snippet, Chief Justice Traynor notes this: "The exclusion of parole evidence [relevant to meaning] . . . can easily lead to the attribution to a written instrument of a meaning that was never intended." 25

But in his cost-benefit analysis, Chief Justice Traynor considered only the costs. The parol evidence rule confers benefits as well. By narrowing judicial fact-finding over written contracts, it reduces the cost of such litigation. The real question is thus whether the benefits of decreased litigation costs outweigh the cost of judicial error. This is the question that Chief Justice Traynor never gets around to discussing in all of his meandering through the philosophy of language and Egyptian mythology. If we assume that the cost of judicial error will be more or less randomly distributed, then we would expect that firms such as Drayage and PG\&E would prefer a relatively formalistic version of the parol evidence rule. ${ }^{26}$ Over the entirety of the firm's life, the effects of judicial error should cancel out-with windfalls offsetting costs-allowing firms to reap the benefits of lower litigation costs. ${ }^{27}$ Such a rule cold-bloodedly assumes that courts will at times frustrate the intentions of contracting parties. However, contract law is ultimately an instrument of commerce, and its users are willing to tolerate costs in the pursuit of benefits. ${ }^{28}$ Furthermore, because the traditional formulation of the parol evidence rule hits formally drafted contracts the hardest, parties can avoid its springes by drafting around it with more specific language.

One might reasonably conclude that the costs of the parol evidence rule exceed its benefits. ${ }^{29}$ Many non-common-law systems have no analog to the rule, and the Uniform Commercial Code se-

24. See Alan Schwartz \& Robert E. Scott, Contract Theory and the Limits of Contract Law, 113 YALE L.J. 541 (2003) (arguing that the parole evidence rule concerns the scope of the evidentiary base for judicial decisions).

25. Pac. Gas \& Elec. Co., 442 P.2d. at 645.

26. See Schwartz \& Scott, supra note 24, at 550.

27. See id. at 551 .

28. See Nathan B. OMAn, The Dignity of Commerce: Markets and the Moral FOUNDATIONS OF CONTRACT LAW 13 (2016) ("Contract law is the quintessential legal institution of the marketplace.").

29. See, e.g., Martin-Davidson, supra note 23, at 72 . 
verely modifies it. ${ }^{30}$ However, Pacific Gas's straw-man argument fails to articulate an adequate defense for PG\&E's position, and California courts have largely rejected it. ${ }^{31} \mathrm{~A}$ few years after Pacific Gas, the California Supreme Court again reversed a trial court for failing to consider extrinsic evidence in construing a written contract $^{32}$ This time, Justice Mosk, who joined the majority in $\mathrm{Pa}$ cific Gas, dissented, urging a halt. ${ }^{33}$ According to Mosk, "it has become virtually impossible under recently evolving rules of evidence to draft a written contract that will produce predictable results in court." ${ }^{34}$

Eventually, Justice Mosk won the war. In 1993, the California Supreme Court considered the scope of a choice-of-law clause. ${ }^{35}$ The court rejected an offer of extrinsic evidence and looked only at the four corners of the document. ${ }^{36}$ The court quoted approvingly from Judge Kozinskis's Trident opinion and Mosk's dissent. ${ }^{37}$ Noting that a choice-of-law clause is intended to cut litigation costs, the California Supreme Court concluded that neither party intended "a protracted litigation battle" over the clause's meaning: the Pacific Gas "view of the problem-which would require exten-

30. See U.C.C. $§ 2-202$ (stating that final written agreement "may be explained or supplemented” by various sources); UNITED NATIONS CONVENTION ON CONTRACTS FOR THE INTERNATIONAL SALE OF GOODS, ART. 8(3) ("In determining the intent of a party or the understanding a reasonable person would have had, due consideration is to be given to all relevant circumstances.").

31. See, e.g., Hanson v. McCaq Cellular Commc'ns, Inc., 881 F. Supp. 911, 918-19 (S.D.N.Y. 1995) (applying California law to exclude parole evidnece offered to interpret a contract); ACL Techs., Inc. v. Northbrook Prop. and Cas. Ins. Co., 17 Cal. App 4th 1773, 1790-91 (Cal. Ct. App.1993) ("[California cases] clearly require a showing of ambiguity before extrinsic evidence may be admitted to shed light on that ambiguity."); Lomanto v. Bank of Am., 22 Cal. App 3d 663, 668 (1972) (distinguishing Pacific Gas to exclude extrinsic evidence); Banco Do Brasil, S.A. v. Latian, Inc., 234 Cal. App. 3d 973, 1011 (1991) ("If . . . they agree that their entire understanding is completely set forth in a particular writing then they are both entitled and required to live with the agreed terms. The courts simply cannot permit clear and unambiguous integrated agreements . . . to be rendered meaningless by the oral revisionist claims of a party who, at the end of the game, does not care for the result.").

32. Delta Dynamics, Inc., v. Arioto, 446 P.2d 785 (Cal. 1968).

33. Id. at 789 ("Once again this court adopts a course leading toward emasculation of the parole evidence rule. During this very year Masterson v. Sine and Pacific Gas \& Electric Co. v. G.W. Thomas Drayage \& Rigging Co. have contributed toward that result. Although I had misgivings at the time, I must confess to joining the majority in both of those cases. Now, however, that the majority deem negotiations leading to execution of contracts admissible, the trend has become so unmistakably ominous that I must urge a halt.") (citations omitted).

34. Id.

35. Nedlloyd Lines B.V. v. Superior Court of San Mateo, 834 P.2d 1148 (Cal. 1992).

36. See id. at $1153-55$.

37. See id. at 1154-55. 
sive litigation"- "is more likely the product of postdispute litigation strategy, not predispute contractual intent." 38

Thus died the Summer of Love's foray into contract doctrine.

38. Id. at 1154 ("Our conclusion in this regard comports with common sense and commercial reality. When a rational businessperson enters into an agreement establishing a transaction or relationship and provides that disputes arising from the agreement shall be governed by the law of an identified jurisdiction, the logical conclusion is that he or she intended that law to apply to all disputes arising out of the transaction or relationship. ... Nor do we believe such a person would reasonably desire a protracted litigation battle concerning only the threshold question of what law was to be applied to which asserted claims or issues. Indeed, the manifest purpose of a choice-of-law clause is precisely to avoid such a battle."). 
Farash v. Sykes Datatronics, Inc.

\section{JEAN FLEMING POWERS ${ }^{*}$}

It is easy to nominate Farash $v$. Sykes Datatronics, Inc. ${ }^{1}$ as one of the worst contracts cases, but it is more difficult to decide how to present it. The difficulty springs not from an inability to find flaws in the majority opinion, but rather from the glaring nature of the flaws and the fact that the dissent already provides a very able critique of the opinion. Yet on reflection, one of the most telling deficiencies in the case is the fact that the majority had the benefit of the dissent's excellent analysis and nonetheless chose to discount it.

The case fails to accomplish at least three important goals that an opinion of the highest court in a state should accomplish: (i) it should provide clear guidance to lawyers and parties in future cases; (ii) it should follow established legal rules or clearly state how and why it is changing those rules; and (iii) it should not undermine clearly established state public policy. The first two of these failures are intertwined in that the failure to either follow, or clearly change, current rules necessarily makes the law murkier and less accessible to future litigants.

The plaintiff in Farash sued the defendant based on the defendant's breach of an oral agreement to lease real property for a term longer than a year. The plaintiff sought to recover for expenditures and improvements made to the plaintiff's own building in preparation for the defendant's occupation. Two of the plaintiff's causes of action were barred by the Statute of Frauds. The court found for the plaintiff on his second cause of action, however, on the theory that he "merely [sought] to recover for the value of the work [he performed] in reliance on statements by and at the request of [the] defendant." ${ }^{2}$ The majority facilely dismissed any Statute of Frauds defense based on this promise, choosing to compensate the plaintiff for "those efforts that were to his detriment and that thereby placed him in a worse position." ${ }^{3}$ The goal of compensating the plaintiff under these circumstances may be admirable, but it is unsupported by any specified legal theory. ${ }^{4}$ On the contrary, the majority asserts that the court "should not be

* Professor of Law, South Texas College of Law Houston.

1. 452 N.E.2d 1245 (N.Y. 1983).

2. Id. at 1246 .

3. Id.

4. See id. at 1249 (Jasen, J., dissenting) ("The majority fails to specify the theory of recovery upon which it bases its conclusion."). 
distracted by the manner in which a theory of recovery is titled," ${ }^{5}$ leaving future plaintiffs and their attorneys without guidance as to how to describe their future claims.

Thus, in choosing to remain relatively unencumbered by a need to specify a clear theory, the court fails to accomplish the first two goals. Worse yet, it misstates and misapplies settled law to support the result. It cites Professor Arthur Luther Corbin and the Restatement (Second) of Contracts for the proposition that reliance damages, including "expenditures made in preparation for performance," may be recovered, ${ }^{6}$ but fails to explain why this contract measure of damages should be available to a party who has no enforceable contract on which to sue. ${ }^{7}$ It makes the same misstep in citing Professors John Calamari and Joseph Perillo regarding a restitution analysis, ${ }^{8}$ despite the fact that the discussion it quotes deals exlusively with breach of contract claims. ${ }^{9}$ The court thus adds to the already problematic confusion about reliance, which is a damage recovery, and restitution, ${ }^{10}$ which is not. It further adds to the existing confusion about when conferred benefits support a restitution claim, and how the measurements of those benefits are affected by the context. ${ }^{11}$

Further, the court fails to accomplish the third goal when it fails to adequately address why a recovery should be allowed for a promise made in the context of the unenforceable contract. As astutely pointed out by the dissent, the claim is "merely . . . a blatant attempt to circumvent the proscriptions of the Statute of Frauds." ${ }^{12}$ In choosing to enforce the promise, the court potentially undermines the important policy underpinnings of the Statute of Frauds. There may be very little left of a Statute of Frauds defense if plaintiffs are prohibited from enforcing oral contracts but are free to enforce oral

\section{Id. at 1248 .}

6. Id. at 1247 (citing RESTATEMENT (SECOND) OF CONTRACTS $§ 349$, $\$ 370 \mathrm{cmt}$. a (AM. LAW INST. 1981) and 5 CORBIN ON CONTRACTS 578).

7. Id. at 1250-51 (Jasen, J. dissenting) ("This passage, by its very terms, deals solely with remedies available where a party has breached an existing contract.”).

8. Id. at 1248 (citing John D. CALAMARI AND JOSEPH M. PERILlo, CONTRACTS $\S \S 15-$ 4, 19-44 (2d ed. n.d.)); Joseph M. Perillo, Restitution in a Contractual Context, 73 CoLUM. L. REV. 1208, 1219-25 (1973).

9. Id. at 1250 (Jasen, J. dissenting).

10. Cf. Douglas Laycock, The Scope and Significance of Restitution, 67 TEX. L. REV. $1277,1282-83$ (1989) ("[R]estitution of the value of what plaintiff lost is simply compensatory damages. Used in this sense, 'restitution' loses all utility as a means of distinguishing one body of law from another. Restitution must be distinguished from compensation, either by its focus on restoration of the loss in kind or by its focus on defendant's gain as the measure of recovery.").

11. See generally Dan B. DoBbS, 1 DoBbs LAW of REMEdes: Damages, EQUTT, RESTITUTION § 4.1(1) (2d ed. 1993) ("Most generalizations about restitution are trustworthy only so long as they are not very meaningful, and meaningful only so long as they are not very trustworthy.").

12. Farash, 452 N.E.2d at 1249 (Jasen, J., dissenting). 
"promises." The dissent notes that the majority seems to be in fact "recognizing a cause of action sounding in promissory estoppel." 13 Yet the majority barely mentions the theory. ${ }^{14}$ And as the dissent further points out, the issue was not pleaded, addressed, argued, or briefed, making any application in this case "ill-advised."15 Section 139 of the Restatement (Second) of Contracts, referenced by the majority, is a carefully considered provision designed to prevent injustice while respecting the importance of the Statute of Frauds. ${ }^{16}$ Thus, as the dissent rightly points out, not only is it unwise to apply the section without argument by the parties, but to the extent that relevant facts exist in the record, they militate against application in this case. For example, one of the factors in the Restatement is "the extent to which the action . . . corroborates evidence of the making and terms of the promise . . .."17 As the dissent notes:

[A] sophisticated businessman such as Max Farash knew that he could have easily insured that defendant would pay for the extensive renovation work plaintiff performed on his own building merely by obtaining defendant's promise to that effect. Plaintiff's failure to obtain such a promise leads inevitably to the conclusion that defendant never intended to pay for [it] and, thus, never agreed to do so. ${ }^{18}$

Thus, not only does the claim fail under the Statute of Frauds, it also fails to meet the high standards for a promissory estoppel claim because of its untrustworthiness - which speaks to the underlying purpose of the Statute of Frauds.

An examination of the opinion thus undermines the most plausible theory of recovery - promissory estoppel. The reliance theory is also easily discredited because it is a damage recovery for breach of contract, and there is no enforceable contract in the case. The majority further fails to justify any restitution recovery by relying on inapplicable authority and failing to explain how, under these facts, a defendant that "did not benefit from [the] plaintiff's efforts"19 is unjustly enriched and should be required to pay for the enrichment. The issue is thus not so much whether the court is "distracted by the manner in which a theory of re-

13. Id. at 1251 .

14. The majority's one citation to section 139, which it cites along with section 349 , without further comment, follows the simple statement: "The Restatement recognizes an action such as is involved here." Id. at 1247 (majority opinion) (citation omitted).

15. Id. at 1251 (Jasen, J., dissenting).

16. See generally RESTATEMENT (SECOND) OF CONTRACTS $\$ 139 \mathrm{cmt}$. b (AM. LAW INST. 1981) (dealing with the need to balance avoidance of injustice with the need to fulfill the purposes of the Statute of Frauds).

17. Id. $\S 139(2)(\mathrm{c})$.

18. Farash, 452 N.E.2d at 1251 (Jasen, J., dissenting).

19. Id. at 1246 (majority opinion). 
covery is titled," ${ }^{20}$ but whether the reader of the opinion is distracted by the court's inept discussion of the various candidates for a theory to support the result. 


\section{How Did We End Up in a World Where Browsewraps Are Enforced Even When They Waive All Consumer Rights?}

\section{Cheryl B. PRESTON ${ }^{*}$}

In Lochner $v$. New York,${ }^{1}$ the Supreme Court struck down a law preventing employers from requiring their employees to work over sixty hours per week, finding it an impermissible invasion of the freedom of contract. ${ }^{2}$ The Court supposedly believed that bakers who agreed to work more hours as a condition of employment had a meaningful choice. Lochner is one of the most reviled cases in American jurisprudence, ${ }^{3}$ although critics have differing reasons. ${ }^{4}$ I focus on the Court's misapplication of "freedom of contract," which reinforced existing "distributions of wealth as natural and prelegal" 6 and ignored the implications for abuse by the powerful. Lochner turned "freedom of contract" from the gift of the king requiring lords to allow serfs to decide the terms of their own service back to freedom of the powerful to impose terms on the weak with-

* Edwin B. Thomas Professor of Law Emeritus, J. Reuben Clark Law School, Brigham Young University.

1. 198 U.S. 45 (1905).

2. Id. at 46 .

3. "Lochner $v$. New York would probably win the prize, if there were one, for the most widely reviled decision of the last hundred years." David A. Strauss, Why Was Lochner Wrong?, 70 U. CHI. L. REV. 373, 374 (2003). See also Kenji Yoshino, A New Birth of Freedom?: Obergefell v. Hodges, 129 HARV. L. REV. 147, 170-71 (2015) ("The Lochner decision is seen as the paradigmatic case of judicial activism, and is one of the most reviled cases in constitutional law."); David E. Bernstein, Lochner's Legacy's Legacy, 82 TEX. L. REV. 1, 2 (2003) ("Almost one hundred years after [the case was decided]. . . Lochner and its progeny remain the touchstone of judicial error."); Richard A. Primus, Canon, Anti-Canon, and Judicial Dissent, 48 DUKE L.J. 243, 245 (1998) ("Lochner and Plessy are anti-canonical cases.”).

4. Michael J. Phillips, The Progressiveness of the Lochner Court, 75 DENV. U. L. REV. 453, 457 (1998) (defining the three criticisms of Lochner as excessive activism in overturning a state legislature, the Court's innocent but misguided embrace of "traditional economic liberties," and the Court's intentional deference to wealth and power). Although many argue that "Lochner was wrong because it involved . . . an illegitimate intrusion by the courts into a realm properly reserved to the political branches of government," Cass Sunstein argues that the error was assuming that market ordering was a "part of nature." Cass R. Sunstein, Lochner's Legacy, 87 COLUM L. REV. 873, 874 (1987). But see Bernstein, supra note 3.

5. Julie E. Cohen, Lochner in Cyberspace: The New Economic Orthodoxy of "Rights Management", 97 MICH. L. REV. 462, 465 (1998) ("Lochner represented a . . social ordering premised on a seamless convergence of the private-law institutions of property and contract to provide a zone of legal insulation for market outcomes. In the physical world, that vision has long been compromised by evidence of market failures that all but the most die-hard Chicago school economist cannot help but acknowledge.") (footnote omitted); James L. Kainen, The Historical Framework for Reviving Constitutional Protection for Property and Contract Rights, 79 CORNELL L. REV. 87, 91-92 (1993) (noting Lochner's "unrestrained protection of economic rights that permitted the judiciary to import illegitimately laissez-faire, probusiness policy preferences into its explication of the constitutional text. . . Freedom of contract protected those already possessed of economic power at the expense of the masses.").

6. Bernstein, supra note 3 , at 13 . 
out any governmental oversight. ${ }^{7}$ Despite the vilification of Lochner for over a century, courts are returning to Lochnerian philosophy as a revival of "classicism" or "formalism."

In accepting adhesive form contracts, Karl Llewelyn recognized the arguments of "classicism," favoring certainty, stability, and efficiency. ${ }^{9}$ Nonetheless, he noted that their enforcement must be tied to a jurisprudence that allowed, if not required as a moral imperative, judges to police abuses. "What has . . . been assented to," Llewellyn noted:

[A]re the few dickered terms, and the broad type of the transaction, and but one thing more. That one thing more is a blanket assent (not a specific assent) to any not unreasonable or indecent terms the seller may have on his form, which do not alter or eviscerate the reasonable meaning of the dickered terms. ${ }^{10}$

Even in the absence of Lochner's protective state statute, most courts had relied on good faith to limit the reach of private law even before the UCC provided balanced provisions governing sales and, with the Restatement (Second) of Contracts, articulated the doctrine of unconscionability. ${ }^{11}$ The reasonable protections of the UCC are now overridden by contract law, and the traditional judicial boundaries on abuses have dwindled to nonuse ${ }^{12}$ - amid a flurry of

7. Cheryl B. Preston \& Eli McCann, Llewellyn Slept Here: A Short History of Sticky Contracts and Feudalism, 91 OR. L. REV. 130, 170-74 (2012).

8. Jay M. Feinman, Un-Making Law: The Classical Revival in the Common Law, 28 SEATTLE U. L. REV. 1, 2 (2004).

The practical consequence . . . is that businesses can use contract law more effectively to control relationships . . . because they can more easily dictate the terms of dealing, avoid being legally bound except on their own terms, avoid review by the courts of the fairness of those terms, and control how disputes are resolved under their contracts.

Id. at 16-17. See also Kathryn A. Sabbeth \& David C. Vladeck, Contracting (Out) Rights, 36 FordHAM URB. L.J. 803, 807 (2009) ("In our view, the Supreme Court's embrace of mandatory arbitration reflects a return to a Lochner-like veneration for the freedom to contract unrestrained by public laws ...."); G. Richard Shell, Contracts in the Modern Supreme Court, 81 CAL. L. REV. 433, 436 (1993) ("[T]he modern Court has shown a sustained interest in reconstructing the American legal system to better reflect economists' ideal of strict contract enforcement."); Stelluti v. Casapenn Enters., LLC, 1 A.3d 678, 702 (N.J. 2010) (Albin, J., dissenting) (arguing that the court revived Lochner and placed the right to contract over policy concerns).

9. Karl N. Llewellyn, What Price Contract?-An Essay in Perspective, 40 Yale L.J. 704, 731 (1931). For a description of these values, see Meredith R. Miller, Contract Law, Party Sophistication and the New Formalism, 75 Mo. L. REV. 493, 498-99 (2010).

10. KaRL N. LleWELlyn, THE COMMON LAW TRADITION: DECIDING APPEALS 370 (1960).

11. U.C.C. § 2-302 (AM. LAW INST. \& UNIF. LAW COMM’N 2017); RESTATEMENT (SECOND) OF CONTRACTS $§ 208$ (AM. LAW INST. 1979).

12. Jane K. Winn \& Brian H. Bix, Diverging Perspectives on Electronic Contracting in the U.S. and EU, 54 CLEV. ST. L. REV. 175, 183-84 (2006). 
law and economics activism. ${ }^{13}$

As we return to Lochnerian illusions of choice and power, we should also reconsider the wisdom from other cases of a prior generation. For instance, the Georgia Supreme Court in 1847 dug to the heart of clickwraps, browsewraps, and other contracts imposed on consumers by supposed "notice" by powerful, repeat players: "If these can vary their liability at all, at what limits does the power stop? [W] here are its boundaries? . . . [With] neither bounds nor limitations; the citizens would be at their mercy, bound by their power and subject to their caprices." 14

The New York Supreme Court in 1838 recognized the issue of commercial efficiency but concluded that boundaries must be maintained:

Where is the boundary? [Some say the service provider] himself is to prescribe it. If this be so, it is easy to see that the common law is overcome, for ... if this question were entrusted to the party instead of the law, the fences against damage and loss would [not] stand for a moment. ${ }^{15}$

Indeed, a powerful party should be unable to change an agreement from "give me a due reward, and I will be accountable" to " 'give me the same reward ... and yet, I claim to throw all risk upon you, or such a degree of it as I please.' "16 Consumers purchasing goods in walkup stores are endowed with the rights provided by the UCC. These rules are, unfortunately, "defaults" that Internet retailers waive by hidden print (although online shoppers pay the same price).

Notwithstanding the decades of anti-Lochner rhetoric, courts are again enforcing overreaching contracts in the name of freedom of contract, Smithian-market myths, and the efficiency of the powerful. Rather than face hard issues about market power and the meaning of the rights waived, courts take the easy route of blaming the victims for assenting — or rather, not for assenting, but for failing to search for a link to legal terms, take a half hour to read them, seek legal counsel to interpret them, and shop for another online

13. Anthony T. Kronman, The Fault in Legal Ethics, 100 DICK. L. REV. 489, 502 (1996) ("By far the most powerful intellectual current in American law teaching today is the law and economics movement. ... [L] aw and economics has a foothold in every area of law, and wherever it has acquired significant prestige ...."). See also, e.g., William J. Woodward, Jr., Neoformalism in a Real World of Forms, 2001 WIS. L. REV. 971, 1004 (2001); Eric A. Posner, Essay, Economic Analysis of Contract Law After Three Decades: Success or Failure?, 112 YALE L.J. 829 (2003); Richard Craswell, In That Case, What is the Question? Economics and the Demands of Contract Theory, 112 YALE L.J. 903 (2003); Ian Ayres, Valuing Modern Contract Scholarship, 112 YALE L.J. 881 (2003).

14. Fish v. Chapman, 2 Ga. 349, 361-62 (1847).

15. Cole v. Goodwin, 19 Wend. 251, 273-74 (N.Y. Sup. Ct. 1838).

16. Id. at 277 . 
service or goods provider with less onerous terms, even though one is unlikely to be found. ${ }^{17}$ At least the bakers in Lochner signed a written document. But even that form of assent is no longer required. 
Pillans and Rose v. Van Mierop and Hopkins: The Worst Way to Win

\section{VAL RICKS}

Judges should explain and justify, not obfuscate or mislead. Against these ideals, Pillans $v$. Van Mierop ${ }^{1}$ ranks among the worst contract cases. Its prominence renders it the worst.

White presented to Pillans and Rose (Pillans), who were merchants in Rotterdam, a draft (like a check) ordering Pillans to pay Clifford. ${ }^{2}$ To encourage Pillans to accept and pay the draft, White proposed "to give them a credit upon a good house in London . . . or any other method of reimbursement." 3 Pillans opted for "a house of rank in London." ${ }^{4}$ For a London house, White offered Van Mierop and Hopkins (Van Mierop). ${ }^{5}$ Without any promise from Van Mierop, Pillans paid Clifford $£ 800 .^{6}$ No one had yet spoken with Van Mierop. ${ }^{7}$

Later, Pillans wrote to Van Mierop asking whether Van Mierop would accept and pay a draft for the $£ 800 .{ }^{8}$ Van Mierop promised to pay the draft if submitted, which ultimately became the promise at issue. ${ }^{9}$ However, White soon contacted Van Mierop and "stopt payment." ${ }^{10}$ Van Mierop then contacted Pillans and repudiated its promise. ${ }^{11}$ Pillans had not yet sent Van Mierop a draft. ${ }^{12}$ Only later, knowing Van Mierop would not pay, did Pillans send the draft. ${ }^{13}$ Van Mierop rejected it, and Pillans sued for breach of promise. ${ }^{14}$ Lord Mansfield, the trial judge, thought Pillans should win,,$^{15}$ but the jury exonerated Van Mierop. ${ }^{16}$

* Charles Weigel II Research Professor and Professor of Law, South Texas College of Law Houston.

1. (1765) 97 Eng. Rep. 1035 (K.B.).

2. Id.

3. Id.

4. Id. Pillans stipulated the London house "as the condition of their accepting the bill," but paid even before contacting Van Mierop. Id.

5. Id.

6. Id.

7. Id.

8. Id.

9. Id.

10. Id.

11. Id.

12. Id. Pillans's last letter, before sending the draft, confessed knowledge of the stop payment order and Van Mierop's repudiation.

13. Id.

14. Id.

15. Id. at 1036 .

16. Id. at 1035 . 
On appeal, Lord Mansfield, with Justices Wilmot, Yates, and Aston, voted to discard the verdict. ${ }^{17}$ Why? After all, Van Mierop's promise was without consideration. ${ }^{18}$

The judges claimed Van Mierop's promise was "a mercantile transaction" and thus "quite upon another foundation than" mere contract. ${ }^{19}$ But this was just a label that was neither explained nor justified. No "custom of merchants" was proved. ${ }^{20}$ And what Van Mierop did was quintessentially contractual - he promised to pay. Even if the move is logical, it appears lawless.

The court also equated Van Mierop's promise with accepting a draft, as if a promise to create a negotiable instrument was the same as creating one; Mansfield said, "[T]his credit is [already] given." ${ }^{21}$ But it was not. Van Mierop repudiated the promise before Pillans submitted the draft. Also, on this view, sending the draft would merely satisfy a condition, and "accepting the draft," which would normally occur only when a draft was sent, would in this case not be to accept the (already accepted) draft. Even Mansfield later discarded this rationale. ${ }^{22}$ The judges, moreover, believed that contract law applied-else why spend most of their time misstating the consideration requirement to support the result?

Regarding consideration, Mansfield famously claimed that it is "for the sake of evidence only," ${ }^{23}$ and so a promise's being in writing (as Van Mierop's was) satisfied it. In support, "he asked, if any case could be found, where the [promise] holden to be a nudum pactum was in writing." ${ }^{4}$ The answer to his question is no-no such promise can be found, but the question and answer do not help his claim at all. An assumpsit action did not require a written

\footnotetext{
17. Id. at $1038,1040-41$.

18. Id. at 1035,1037 .

19. Id. at 1036 (Mansfield); see also id. at 1036-37 (Wilmot), 1038 (Mansfield), 1040
} (Yates).

20. Id. at 1041 .

21. Id. at 1036; see also id. at 1037-38, 1040-41 (Mansfield, Wilmot, Yates, Aston).

22. See Pierson v. Dunlop (1777) 98 Eng. Rep. 1246, 1248 (K.B.) (Mansfield: "It has been truly said as a general rule, that the mere answer of a merchant to the drawer of a bill, saying, 'he will duly honour it,' is no acceptance; unless accompanied with circumstances which may induce a third person to take the bill by indorsement."). The English courts followed Pierson over Pillans. E.g., Bank of Ireland v. Archer (1843) 152 Eng. Rep. 852,855 (K.B.) ("[A] promise to accept a non-existing bill [is] no acceptance." (citing Johnson v. Collings (1800) 102 Eng. Rep. 40 (K.B.))); Johnson v. Collings, supra.

23. Pillans v. Van Mierop (1765) 97 Eng. Rep. 1035, 1037-38 (K.B.); see id. at 1041 (Aston).

24. Id. at 1037 . 
promise, ${ }^{25}$ so no reason existed to show a writing in assumpsit actions. (Mansfield knew this.) ${ }^{26}$ The absence of irrelevant evidence is not evidence of its relevance. What is more, the Statute of Frauds, passed in 1677 , made a writing necessary in certain cases. ${ }^{27}$ If consideration were not required when a writing existed, then the Statute of Frauds obviated consideration in those cases 100 years earlier. But it did not. ${ }^{28}$ Finally, the courts that invented consideration made some purposes clear. One was evidence, ${ }^{29}$ but caution was more prominent. ${ }^{30}$ Mansfield's argument is careless thinking at best, ${ }^{31}$ and all of the other judges rejected it at a later hearing. ${ }^{32}$

Mansfield and Wilmot also cite "specialties, bonds, etc." as writings requiring no consideration, ${ }^{33}$ but they knew these documents were sealed and that the seal, not the writing, was the binding formality..$^{34}$ Perhaps Mansfield was deliberately misstating the law so as to reach his preferred result..$^{35} \mathrm{He}$ afterwards decided that a promise

25. E.g., Golding's Case (1586) 74 Eng. Rep. 367, 367 (Q.B.); see also every assumpsit case decided before 1765 .

26. See, e.g., Mayor of Yarmouth v. Eaton (1763) 97 Eng. Rep. 896 (K.B.) (holding that making a port is consideration for a toll); compare Eaton with Shubrick v. Salmond (1765) 97 Eng. Rep. 1022 (K.B.) (Lord Mansfield, in response to a consideration objection in a covenant action: "A man may, without consideration, enter into an express covenant under hand and seal.”).

27. Statute of Frauds, (1677) 29 Car. 2 c. 3.

28. Rann v. Hughes (1778) 101 Eng. Rep. (H.L.) 1014 n.(a) (see discussion infra note 31).

29. Sharington v. Strotton (1565) 75 Eng. Rep. 454, 460 (Q.B.).

30. Id. at 470. Wilmot in fact notes this in Pillans v. Van Mierop (1965) 97 Eng. Rep. 1035, 1038-39 (K.B.).

31. Both Lord Mansfield and Lord Wilmot's thinking twisted consideration with the Statute of Frauds' category “debt of another.” Pillans v. Van Mierop 97 Eng. Rep. at 1036 ("The mere promise 'to pay the debt of another,' without any consideration at all, is nudum pactum. . . The statute must mean . . .."); id. at 1038. Defendants argued that they were, as a stranger to the consideration, being asked to pay "another man's debt," id. at 1035; this language perhaps summoned the Statute of Frauds to the judges' minds. It is a false connection. The Statute of Frauds is merely negative (a promise "is not enforceable unless" it is in writing), not positive (which would be "is enforceable if"), as the Lords later noted in Rann, supra note 23. Pillans's conflation of consideration and the Statute suggests the judges were uninformed about basic case law cited to them. See 97 Eng. Rep. at 1035 (citing Hunt v. Bate, Dyer 272 (1568), the leading case rejecting past consideration, decided 109 years before the Statute of Frauds was passed). Or the judges deliberately misread the arguments. The Statute of Frauds was their straw man. Contra A.W.B. SIMPSON, A HISTORY OF THE COMMON LAW OF CONTRACT 617-19 (1975) (attempting a rather tepid defense of Lord Mansfield, who, Simpson admits, was only repeating some careless statements he had heard from prior judges).

32. Pillans, 97 Eng. Rep. at 1039 \& 1039 n.(e) (Wilmot, J.) (reporting that the judges in the Exchequer Chamber agreed that a writing was not enough).

33. Id. at 1038-39 (in the discussion of Sharington).

34. See, e.g., Lowe v. Peers (1768) 98 Eng. Rep. 160, 161-63 (K.B.) (Mansfield's rejecting arguments for lack of consideration in a covenant action based on a sealed writing, where Mansfield "stated the deed particularly" and emphasized the jury's finding that "it was [Peers's] deed”); Shubrick, 97 Eng. Rep. at 1022 (see supra note 26).

35. Mansfield also claimed that no one argued lack of consideration to the jury. Pillans, 97 Eng. Rep. at 1036, 1038-39. But that only mattered if consideration were waivable. 
made for love and affection, "written out and attested by ... witnesses," needed no consideration. ${ }^{36}$ (The House of Lords later held this erroneous. $)^{37}$

The judges also tried a reliance argument- "Pillans . . . trusted to this undertaking" 38 _but this is speculation. ${ }^{39}$ At best, the judges suggest that Pillans did not try other means of collecting from White, but there is no evidence supporting this: Van Mierop did not require it, and only the judges assert it. Not even the plaintiff's lawyers argued reliance. Also, as Mansfield noted, "it does not seem at all that [Pillans] then doubted of White's sufficiency." 40 So it is unlikely that Pillans refrained in reliance. Implying consideration by speculating that a promise induced another to do nothing fictionalizes the requirement-it allows mere imagination to satisfy the law.

Thirteen years later, the House of Lords explicitly rejected everything the Pillans court said about consideration. ${ }^{41}$

What should have happened? Wilmot recognized consideration's evidentiary, cautionary, and channeling functions. He suggested that, if these were met, a promise could be enforced without consideration. ${ }^{42}$ Consideration also gives courts (i) a chance to preview the fairness of enforcement and (ii) grounds (absent other evidence) for a bargain-focused remedy. ${ }^{43}$ Had Wilmot (a) explained how this substance was met and (b) articulated a clear rule for when consideration could be dropped, the opinion would succeed. But he did not. "I give no opinion for its being good, always, when in writing," he ad-

Consideration was part of the plaintiff's prima facie case, however, as Mansfield knew. E.g., Sidenham v. Worlington (1585) 74 Eng. Rep. 497, 498 (C.P.).

36. Williamson v. Losh (1775) (K.B.). For various citations to this manuscript case, see JAMES OLDHAM, ENGLISH COMMON LAW IN THE AGE OF MANSFIELD 85 n.38 2004).

37. Rann v. Hughes (1778) 101 Eng. Rep. (H.L.) 1014-15 n.(a).

38. Pillans, 97 Eng. Rep. at 1036 (Mansfield), 1037 (Wilmot), 1039 (Wilmot), 1040 (Yates).

39. See id. at 1039-41 (Wilmot \& Yates). That non-bargained-for reliance could constitute consideration was a well-established legal fact even though the form of the law did not explicitly recognize it. See, e.g., Val D. Ricks, The Sophisticated Doctrine of Consideration, 9 GEO. MASON L. REV. 99, 112-18 (2000). Aston tried a similar argument: Van Mierop's promise "is an admission of having effects of White's in their hands.' " Pillans, 97 Eng. Rep. at 1041. On this argument, Van Mierop was liable in indebitatus assumpsit, the equivalent of unjust enrichment. But possession of White's property is also speculation.

40. Pillans, 97 Eng. Rep. at 1038.

41. See Rann, 101 Eng. Rep. at 1014-15 n.(a).

42. Pillans, 97 Eng. Rep. at 1038 ("such promises were binding"), 1039 ("[i]n another instance, the strictness has been relaxed”). I made a similar argument years ago. See Ricks, supra note 41, at 133-43.

43. See Val Ricks, Consideration and the Formation Defenses, 62 U. KAN. L. REV. 315, 335-43 (2013). 
mitted. ${ }^{44}$ Had the judges understood consideration well enough, they might have cobbled together a persuasive argument and distinction.

Wilmot also recognized a need for international uniformity. ${ }^{45}$ This along with a demonstration of real commercial needs might have won the day. Courts are supposed to make new rules to govern new cases, and this case was new. But Wilmot only mentioned these by label.

Though the arguments failed, the Pillans result now holds in the United States. The promise of Van Mierop would be a "letter of credit." ${ }^{\prime 6}$ It would be enforceable by statute ${ }^{47}$ without consideration ${ }^{48}$ By statutory default, it would be irrevocable. ${ }^{49}$ But Pillans settled nothing. Courts and commentators wrangled about consideration in letters of credit until the UCC resolved the issue ${ }^{50}$ Irrevocability was not the clear default until $1995^{51}$ and not effective in all U.S. jurisdictions until $2008 .^{52}$ (In England, the issue is not yet clearly settled.) ${ }^{53}$ International practice settled on default irrevocability only in the 1990 s. $^{54}$ Ignorance, confusion, or willing obfuscation in 1765 resulted in 220 more years of uncertainty.

44. 97 Eng. Rep. at 1039. The judges one level of appeals higher agreed. See supra note 32 .

45. Pillans, 97 Eng. Rep. at 1040.

46. See U.C.C. $\S \S 5-102(a)(10), 5-104$ (1995). Justice Story tied Pillans to today's letter of credit law in Russell v. Wiggin, 21 F. Cas. 68, 74-76 (1842); see also U.C.C. \$ 5-105 cmt.; JAMES E. BYRNE, 6B HAWKLAND UCC SERIES § 5-105:2 [Rev] (Carl S. Bjerre, ed. Dec. 2016 Update).

47. U.C.C. $\S \S 5-106(a), 5-108(a)$.

48. Id. § 5-105.

49. Id. §5-106(a)-(b).

50. See BYRNE, supra note 46, § 5-105:2 [Rev] nn.3, 5 .

51. Compare U.C.C. § 5-106 (1995) with U.C.C. § 5-106 (1992).

52. See BYRNE, supra note 48, §5-101:2 [Rev].

53. See Raiffeisen Zentralbank Osterrweich AG v. China Marine Bunker (Petrochine) Co., (2006) EWHC 212 (Q.B. Comm).

54. U.C.C. $\$ 5-101: 2$ [Rev]. 